|| || |||||||||| || || || ||

* 31822011492725

Un 


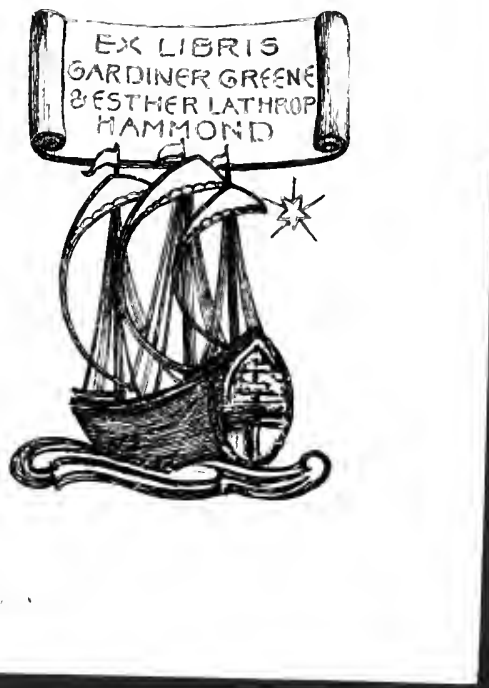




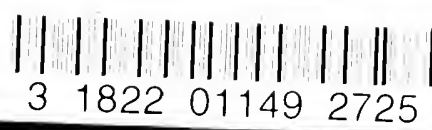


WM

100

p956n

1885

FII 
Digitized by the Internet Archive in 2008 with funding from Microsoft Corporation 


\title{
THE NATURE OF MIND
}

\author{
AND \\ HUMAN AUTOMATISH.
}

B Y

MORTON PRINCE, M.D.,

PHYSICLAN FOR NERTOLS DISEASES, BOSTUN DISPEXARR; PIISICLAN FOR NERYOUS DISEASE, OCT-PATIENT DEPAFTMENT, BOSTON CITI HOSPITAL, RTE.

P'II I, I DEI, III I:

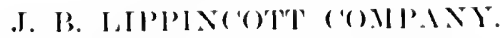

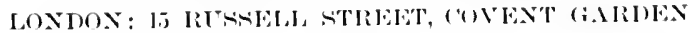

$18 \times 5$. 
Copyright, 185.j, by Morton Prince.

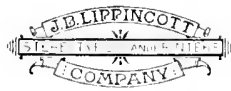




\section{PREFACE.}

The basis of the following work was written some eight or nine years ago during my student days at the medical school, and afterwards served as a graduation thesis. Having been urged to publish this thesis by my friends, it was enlarged between two and three years ago to its present size. I do not think that the views expressed in the earlier essay have been changed in any important particular, though the phraseology has been in many passages altered, partly to make it harmonize with the conventional forms of expression used generally by writers on this subject, and partly because mature reflection made me aware that some of the original terms and phrases employed either did not correctly explain my meaning, or were laeking in preeision and consequently capable of different interpretations. Many points which were of neeessity merely toucher upon in the earlier essiay and hence liable to misinterpretation, have been since greatly expanded, and, especially in the chapter on "Self-Determination," explained more fully, extended reasons being given for the eonclusions expressed. The final chapter, on "Materialism," lats been entirely added. As I have pursued my studies on this subject, the views of other writers have been so far incorporated and criticised at has been thought wonld make the subject-matter clearer. 
The primary object of this book is to discuss certain problems of mind and matter-particularly the relation between the mind and the brain-simply as questions of psychology and physiology, without regard to the bearing they may have on philosophical doctrines. Still, all such questions lie so deeply at the root of the latter, that it is impossible to discuss the one withont regarding the effect they have upon the other. Hence I have not hesitated to enter into the doctrine of Materialism so far as it is affected by the conclusions arrived at. Such questions as the relation of the mind to the body constitute the foundation of Spiritualism and Materialism. The latter, as a result of the great advancement which has been made by science during the last half-century, has of recent years awakened renewed interest and discussion. This has been directly due in no small degree to the writings of such men, among others, as Spencer, Huxley, Clifford, and Mauds. ley, in England, Vogt, Moleschott, and Büchner, in Germany, who, whether all of them have espoused materialistic opinions or not, have at any rate given new energy to the materialistic school, and aroused the opposition of the anti-materialists. It is not always eal:y, however, to correctly classify many prominent writers, as so much that is directly contradictory is found in their writings. It is not uneommon to read on one page that a given anthor emphatically denies materialism, and on the next to find what is apparently the most pronounced materialism. But, notwithstanding the strong ground on which it is intrenched, and the great help which it has received from science, materialism has met with strong opposition. Its oppo- 
nents, it must be confessed, have made their attacks from all sides, with consilerable vigor, and effectively brought to bear arguments based on philosophy and science. And yet, in spite of all its short-comings, materialism is essentially the philosophy of science, and hence that which must eventually prevail. All attacks against it have served only to show its weak places, not to break it down. Still, it cannot be denied that some of the objections urged against such forms of materialism as have been maintained by even its ablest advocates have been well founded. This, it seems to me, has not been the fault of the doctrine, but rather of its expounders. Not only have false meanings been attributed to it by its. opponents, but even its advocates have not always understood its first principles, and the conclusions which have been drawn from scientific data have sometimes been directly in contradiction to the teachings of experience. Whatever merit the views advocated in the following pages may have, it is to be hoped that they at least harmonize some of the hitherto conflicting theories and faets, and that the really valid objections to materialism are avoided. In the maintenance of the materialistic nature of mind, certain difficultics have almost universally been recognized, especially on the side of "automatism," "self-determination," and in the application of the law of the Correlation of Forces, etc., which it has been difficult to overcome. Nay, more, while it lias been seen that mind is to be regarded as some sort of "manifestation of matter," yet most writers are rcady to admit the impossibility of explaining the exact connection between the two, and confess an insoluble mystery. Many of 
the most thoroughgoing materialists content themselves with stating the intimate union of the mental and physical worlds, without attempting to explain how they are united. The views maintained in the following pages, it is thought, both overcome these difficulties and furnish a satisfactory explanation of many of the mysteries of the mind, including its relation to the body and other kindred questions. The conclusions expressed as to the nature of the mind avoid, I believe, the objections which have proved fatal to other materialistic doctrines.

There is one writer whose writings I regret to have overlooked until long after this work was completed, and a short time before going to press. I refer to the late Professor Clifford, who, so far as I know, is the only writer whose views on the relation of the mind to the body coincide with those expressed in these pages. I regret that it was not practicable to refer to Clifford's writings more fully in the text, but references have been made in foot-notes when there appeared to be reason for doing so.

The original essay was withheld from print cluring these many years for several reasons, not the least among them being the desire to reflect well on so difficult a subject, which has already baflled some of the ablest minds the world has ever produced, before committing myself to a public expression of opinion. But I may add that continued study and maturer thought has only strengthened me in the views originally formed.

Boston, March, 1885. 


\section{OONTENTS.}

PART I.

THE NATURE OF MIND.

\section{H A P T E R I.}

THE MODERN DOCTRINE OF THE RELATION OF THE MIND TO THE BODY.

Introductory-Spiritualism and Materialism-Purpose of this Work-The Physical Basis of Mind-The Theory of Functions-The Theory of Aspects-The Inadequacy of both Theories-The Usual Explanation no ExplanationThe Real Questions to be answered-The Logical Deductions from these Theories inconsistent with the known Facts-The Inadequacy of the Usual Explanation generally recognized; by Spencer; by Tyndall-Fiske-Logical Conditions of the Problem-Bain-One Cause of Hostility to Materialism-The Notion of Double Properties entertained by Tyndall; by Bain-Mind does act upon BodyViews of Lewes

PAaE 


\section{CH A P T E R I I I.}

THE SOLUTION.

PAGE

The Argument-The Brain as the Organ of the MindGrounds for believing Consciousness to be Dependent upon Molecular Motions in the Brain-Nature of the Dependence-Four Possible Explanations-The Second only probable-Consciousness the Reality of Physical Processes-Apparent Paradox-The Real Question not how Physical Processes are transformed into Conscionsness -Lewes-Explanation of the Paradox-Nature of the Assoeiation between Consciousness and the "accompanying Physical Changes" . . . . . . . . . 44-60

\section{CH A P T ER IV.}

THE NATURE OF THE MIND.

The Ultimate Nature of Mind-Consciousness an Ultimate -Difficulty of understanding the Transition between Mind and Body avoided-Carpenter-Ferrier-There are not Two Processes, but One-Feeling is not aceompunied by Molecular Changes-It is not inconceivable that Mind should have been produced from Matter; Reply to Fiske - Spencer and the Substance of Mind-The Insuffieiency of the Notion of Mind being a Symbol of something else; also of the Theory of Aspects-Matter and Mind as Different Modes of apprehending something else-Deductions from the foregoing Principle. . . . . . 61-82

\section{H A P T E R V.}

THF CORRELATION OF FORCES.

The Applicability of the Law to Mental Action-Meaning of the Law-Objections to its $A$ pplication as offered by Fiske-Objeetions answered-Materialism not ineonsistent with this Law . . . . . . . . . . $\quad$. $\quad$. $83-90$ 


\title{
PART II. \\ HUMAN AUTOMATISM.
}

\author{
CHA PTER I. \\ THE REFLEX CHARACTER OF IDEAS.
}

PAGE

Logical Consequences of the Preceding Doctrine-Law of Inertia-Consciousness is Passive, not Active-All Mruscular and Mental Action Reflex-Apparent Objection to this Conclusion-Use of the Term Reflex to describe Psychical Facts.

\section{CH A PTER I I.}

CONSCIOUSNESS AS AN AGENT IN THE DETERMINATION OF BODILY ACTION.

Automatism the Logical Consequence of the Reflex Theory -Automatism modified by the Discovery of the Nature of Mind-Objections to Automatism avoided-Conseiousness an Agent in Determining Action-Lewes and Automatism-Huxley-Objections to Consciousness being a Collateral Product-Experiments on Animals-Interpretation of these Experiments-Case of the Frer h Sergeant . . . . . . . . . . . $99-130$

\section{CH A P T E R I II.}

\section{SELF-DETERMINATION.}

Meaning of Self-Determination-Agency by which it is accomplished-Nature of the Ego-Self-Determiuation compatible with the Reflex Theory and AutomutismAll Action deternined by the Strongest Motive-Revery and Deliberation-Coleridge-Mozart-General Conclnsions. 


\section{CHA P T E R I V.}

\section{WHAT IS MATERIALISM?}

Vagueness in the Term-Materialism Misunderstood-False Meanings attributed to the Term-Only Two Positions upon which we can stand-Showing that Mind is the Reality of Matter does not transfer it to SpiritualismAny Doctrine which in Substance accepts this is Materialism-Evolution shows that External Forces are allied in Nature to Consciousness-Materialism does not impair the Dignity or Attributes of anything in the UniverseThe Discovery of the Causation and Origin of Phenomena does not alter the Phenomena themselves-Materialism in one Respect more elevating than any other DoctrineThe Morality of Materialism-Evolution of Moral Principles-Highly-developed Brain necessary for High Standard of Morals among Races-High Standard impossible among the Lower Races-Ihustrations of this-Absence of the Moral Codes of Civilized Nations not Evidence of the Absence of all such Codes in Lower Races-Theological Codes best suited to Man in his Present State 149-173 


\section{PAR T I. \\ THE NATURE OF MIND.}

"THE very idea of so noble, so refined, so immaterial, and so exalted a being as the anima, or even the animus, taking up her residence, and sitting dabbling, like a tadpole, all day long, both summer and winter, in a puddle, or in a liquid of any kind, how thick or thin soever, he would say, shocked his imagination: be would searee give the doetrine a hearing." - Tristram Shandy, B. ii. cb. 19 . 



\section{CHA P T ER I.}

THE MODERN DOC'TRINE OF THE RELATION OF THE MIND TO THE BODY.

"WHEN men have once acquiesced in untrue opinions," remarks Hobbes, " and registered them as authenticated records in their minds, it is no less impossible to speak intelligibly to such persons than to write legibly on a piece of paper already scribbled over." Hence it is that any inquiry like that which is the subject of this work is franght with difficulties, which are due as much to the fact that most men have already acquiesced, withont question, in opinions of transmitted authority as to the inherent obscurity of the matter. And although those, who have given especial thought to such questions, and from the stand-point of modern science have studied anew the problem of the relationship of the mind to the body, have arriverl at conclusions differing largely from the orthodox beliefs held by the majority of even educated people, still, for a long time to come, it cannot be expected that these conclusions will be very widely aceepted, until at least radical changes are made in modern methods of education. And yet, if all men could and would wipe out from their minds, as with a sponge, all existing opinions on such matters, and would begin anew to build up a doctrine of the nature of mind which should be in harmony with existing knowledge, there can be no doubt that a very different opinion would be arrived 
at than that which obtains to-day. It is very difficult for any one, brought up with certain ideas and beliefs, to sufficiently set aside these preconceived notions to give due weight to evidence offered by those of an opposed way of thinking. This is one of the reasons, aside at least from the inherent difficulty of the subject and the lack of exact knowledge of the mechanism of the nervous system, why there has been so much difference of opinion regarding the relation of the mind to the body, and why the opinion maintained by the generality of people differs so widely from that held by the leaders in advanced thought. But though there is a wide ehasm between the notions of the unlearned and the scientific writers of the day, there is an equally wide one between the latter and another class of men, who, though learned in such matters, still, from the force of conservatism, adhere to ancient scholastic creeds. The philosophical world to-day is divided, as it always has been, into two schools of philosophy,the spiritual and the material, though the latter may be said to be the exponent of modern science.

Spiritualism endeavors to explain all mental phenomena by presupposing the existence of a spiritual something acting through the brain as its instrument: materialism looks to the properties of matter alone for a solution. But while spiritualism simplifies the problem by postulating what in one sense may be considered a definite, if incomprehensible, factor, materialism on the other hand, protean in its forms, embraces many doctrines and appears under many guises. Spiritualism simply avoids the difficulty by going around it; materialism boldly enters the labyrinth, but often 
becomes lost in its mazes. Materialism, like spiritualism, was originally the creation of metaphysical speculation, and contained very little that was founded upon established fact. As long as this was the case, as long as materialism was but the product of abstract speculation without positive scientific data upon which to rest, it was nothing more than a mere collection of fanciful hypotheses, without solidity and without substantial support. In this respect it was like unto its opponent spiritualism, and only merited the neglect it formerly received. It is only within the last few decades that sufficient evidence has been eollected, as the result of patient and laborious investigation into the phenomena of nature, to justify the offering of materialism as a satisfactory explanation of the phenomena of the universe and to warrant its aeceptance. With every addition to our knowledge, with every fresh discovery in the domains of science, the deeper we penetrate into the mysteries of nature, the stronger becomes the doctrine of modern materialism; until to-day it offers the most acceptable explanation of the vital problems with which science has to deal. It is difficult to understand how any one, who has taken pains to thoroughly inform himself on the great scicntific questions of the day and is conversant with the discoveries made of late years in the natural sciences, especially in the department of biology, ean fail to find in materialism ${ }^{2}$ the most satisfactory explanation that has yet been

1 It is only fair to say that by materialism $I$ do not mean any of those crude notions which are eommonly attached to the term. By materialism I mean a much higher form of doctrine, which I believe to be the legitimate expression of the scientific thought 
offered of vital phenomena. It is true that what has been accomplished is insignificant compared with what remains to be clone, but with every step forwarl the way becomes clearer and the path surer. In these pages we shall be interested only with that aspect of materialism which deals with the relation between mind and body; an oll question, but one which so far from becoming hackneyed with time, receives increasing interest from every additional discovery made in the physiology of the nervous system. We are to-day, for the first time, just begiming to be in a position to inrestigate the problem which nervous physiology alone has properly opened to us and which before has remained as a sealed book. All metaphysical speculation, not founded on physiological data, as to its contents must be looked upon as a series of more or less shrewd guesses, and even with our present knowledge of the functions of the nervous system, we camnot consider that we have more than anrived at the threshold of the inquiry. The time has not yet arrived when we can hope to thoroughly understand the relations of the mental to the physieal workl. Nevertheless, as the merchant fiom time to time stops in the midst of his trimsactions to "take accomnt of stock," so in the progress of science, it is well to oceasionally pause, and east

of the dity, though perhaps it is necessary to admit that some of the exponents of this thought reject, for what appears to me insuflivinut rasons, the term materialism. This may be because this expresion has often been invested with a meaning, crude and anphilosuphical, with which this higher form has nothing in common. What is understood by materialism will bo explained in the finul chapter, to which the reader is referred. 
our eyes over what has been done, to sum up the evidence that has been accumulated, and see whither we are drifting. Accordingly, the writer has ventured in these pages to call attention to that explanation of the problem which seems most in accorlance with the present condition of science. The sulyect has been approached cutirely from a materialistic stand-point, and therefore the spiritualist will probably find little herein to disconcert him. In a subject so prolific in literature as that of the relation of mind and matter, no one can hope to invent a theory that has not at some time or other been previously suggested. At most one can only hope, as fresh additions are made to our knowledge, to bring new and more potent evidence in support of this or that theory, and to read more intelligently by the light of improved science problems that before have been involved in obscurity and veiled in mysticism. In the following pages the writer has simply endeavored to bring forward evidence in support of a theory which has seemed to him most in accordance with known facts, and to explain by natural means phenomena which otherwise border on the mysterious. The doctrines which are maintained have seemed to him to be the only logical sequenees of the grenerally accepted vews held to-lay in regard to the basis of mental processes, and if the latter are accepted the other should be also. How far the views here advocated are in hamony with those of other writers will he noticed later.

If we look a little more elosely into the history of philosophy, it will be fomd that it has always been a tendency of mankind to explain the unknown by a 
resort to mysterious and supernatural agents. This has been true both of animate and inanimate nature. It is a tendency which has prevailed in inverse proportion to the existing knowledge of the cansation of natural phenomena. The wind, the thunder, the lightning, the properties of matter, all have at different times been explained by means of supernatural or immaterial agents. Mind has been no exception to this law; but as the cloud which has hung over our knowledge of biological processes has remained longer unlifted than in other departments of science, the spiritual influence has been longer felt, and mental phenomena have remained for a longer time enshrouded in mysticism.

To-day the weight of authority is in favor of a material basis for all mental phenomena. It is generally conceded that mind depends upon the development of a peculiar matter, the brain, for its existence.

'The brain is a complex organ macle up of what are called nerve-cells and nerve-fibres, the latter serving as conductors, like ordinary telegraph-wires, for the cells, which are the batteries which run the ncrvous mechanism. Of the nerve-fibres, some comnect together the neighboring cells, others cells situated in distant parts of the brain. Other systems of fibres connect the brain with the various parts of the body. Of these latter there are two kinds: one ingoing, called the sensory or centripetal nerves, which convey impressions to the cells of the brain; and the other, outgoing, called motor, or centrifigal, which convey excitations from the cells of the brain to the muscles, viscera, and otlee parts. 'This, in a rough way, is 
the anatomical mechanism of the nervous system. The more minute structure with still other systems of nerves it is not necessary for our purpose to consider. We have here what is callerl a nervous loop. An impression is conveyed from the skin, for example, by way of the ingoing nerves to the brain. Here an agitation ${ }^{1}$ is set up among the molecules of the cells. This agitation is conveyed from cell to cell, a greater or less number being implicated as the case may be; and finally this molecular motion is retransinitted as a nervous current along the outgoing nerves to the muscles to end in muscular action. Now the important point is this: at the moment when the ingoing current reaches the cereliral molecules, a feeling of some sort arises in the individual, and continues as long as these molecules continue in agitation, and ceases when the molecnlar motion ceases. Whenever the molccules of the brain are set into activity, a sensation or thonglit of some kind occurs; and, vice versa, whenever a thought or sensation arises, a corresponding molecular agitation ocenrs. Let us take a concrete example. A man is sitting in his library quictly reading. The rays of light from his book fall upon his retina and excite the terminal filaments of the optic nerve; from liere the impression is earried as a neural current to the brain, and excites the molecules of the cells. Along with this excitement of the cerebral molecules there arises the image called the book, and all the varions thonghts corresponding to the printed words of the page. These thoughts are said

1 Often called undulations, tremors, vibrations, ete. 
to occur side by side with the molecular agitation. Suddenly the cry of "fire" is raised. The man throws down his book, jumps from his chair, and runs down stairs in answer to the alarm. Now what has occurred in his nervous apparatus? The pulsations of the atmosphere corresponding to the sound "fire" have struck upon his auditory apparatus; from there they have been conveyed as a neural undulation or current along the auditory nerve to his brain and there aroused a new set of moleenlar motions; and with them a new set of thoughts has arisen, embracing perhaps a mental picture of the house in flames and of danger to the inmates. But not stopping here, the cerebral motion has been transmitted along the ontgoing nerves to the muscles, and resulted in the actions just described; we have here, from a physical point of view, what is called a nervous circuit. On the one hand we have a scries of molecular motions begiming with irritations of sensory nerves, and passing as cerebral motions through the brain, ending in muscular action; and on the other hand we have states of conscionsness correlated with a portion of that cireuit, the cerebral portion. In this or in some modified form of this consists all nervous and mental action. On this fact is based the doctrine of the physical basis of mind, which recognizes the association and interdependence of molecular motions and consciousness. Underneath, then, every mental act there flows a physical current. With every thought, sensation, or emotion is associated a physical change in a material substance,- - the brain. No mental act can take place without a corresponding physical change; no physical change without a corresponding mental 
act. Such is the usually accepted doctrine of the present day.

According to this view we have two sets of phenomena, two classes of facts, a mental act and a physical change, invariably associated together. But this is very far from explaining the nature of mental processes. The further question is here presented to us, What is the nature of this association? Is it to be looked upon, as many think, as a mere coexistence of dissimilar phenomena, rather than as one in which any dependency of the one upon the other cau be traced? And are we here to place a limit to our inquiries, and consider that the problem has been rednced to its lowest terms? If we are content to do so, very little progress can be said to have been made towards understanding the relationship between mind and matter. Unless some causal or interdependent relation between the two can be established, we shall be very little better off than we were before physiological science undertook to solve the problem.

But, in truth, physiological science docs pretend to go further, though a carefinl study of the teachings of the exponents of the modern school will reveal two different interpretations of the facts, however unanimous they may appear at first sight. These two interpretations may be termed the Theory of Functions and the Theory of Aspects. Both theories I hope to be able to show are neither a sufficient nor correct explanation of the facts.

The basis of both doctrines is a physical substance underlying both series of facts,-the physical disturbances, and consciousness,- - but the relation which the 
two series bear to this substance differs in the two theories. First, as to the Theory of Functions.

After a careful study of the reasoning by which this conclusion las been reached, as well ats of the general meaning which seems to underlie the writings of the prineipal authorities on the subject, I am convinced that there is only one intelligible meaning with which this doctrine can be invested, and that is this: there is one underlying matter or substance; this substance has two properties, - one of these properties is known as those disturbances we call nerve-motions, the other is consciousness; that is, our ideas, sensations, and emotions. When nerve-motions, the one "property" of this matter, is present, consciousness, the other "propcrty," appears simultaneously. Both come and both go side by side together; but why when one appears the other should do so also we do not know. They may be likened to the following ideal case. Let us invest a piece of iron with the properties of magnetism and heat under ideal conditions. Let us suppose (which is not the case) that whenever the temperature of the iron is raised above that of the surrounding air it becomes magnetized, and, conversely, whenever it becomes magnetized the temperature becomes raised. In this case the magnetism conld be said to correspond with conseionsness and heat with nerve-motions.

This simile must not be pushed farther than is intended. In this case of the iron the heat will probably be inferred to be the cause of the magnetism, and vice versa. But this has scarcely been asserted to be the case with mind and the accompanying neural undulations. The analogy is applicable only so far as con- 
cerns the parallelism of the phenomena. Consciousness and nerve-motions are said only to run in parallel circuits. When one is present, the other is also present. They resemble two clocks, which, wound up at the same moment, record the time and strike the hours in perfect harmony. "We can trace," silys Tyndall, "the development of a nervous system, and correlate with it the parallel phenomena of sensation and thought. We see with undoubting certainty that they go hand in hand. But we try to soar in a vacuum the moment we seck to comprehend the connection between them;" ${ }^{1}$ and yet "thought," sars Huxley, "is as much a function of matter as motion is." 2

Although the theory has not often, if at all, been stated as distinctly or boldly as has just been done, still I think I an justified in this interpretation of it. This is the general idea underlying this form of the materialistic doctrine, and is the only meaning which ean be deduced from the writings of such men as have aceepted it, although it may be suspeeted that the very vagueness with which it is often stated is not inclicative of a elear conception of the defined conditions. Furthermore, this interpretation is the only one which is logically compatible with the deductions which have been drawn from the doctrine itself. This I hope to be alble to show later. Till then I shall have to ask the realer to provisionally aceept it. Aceording to this doctrine we may be said to have to $\dot{d}_{0}$ with a unity of substance and a duality of properties.

The Theory of Aspects differs considerably from this,

1 Belfast Address, p. 62.

2 On Descartes. 
thongh the two are sometimes confused and regarded as identical. There is certainly often lacking that precision of language which is essential to a clear understanding of the problem.

According to the Theory of Aspects, consciousness and nerve motions (vibrations) are only different aspects of one and the same underlying substance, which is unknown. This view has perhaps been as clearly expressed by Bain, as by any one else, when he says, "the one substance with two sets of properties, two sides (the physical and the mental), a double-faced unity, would seem to comply with all the exigencies of the case." 1

The same notion has thus been described by Lewes: "There may be every ground for concluding that a logical process has its correlative physical process, and that the two processes are merely two aspects of one event." 2 And again: "The two processes are equivalent, and the difference arises from the difference in the mode of apprehension." 3

The inadequacy of these theories of Functions and Aspects to explain much of the difficulty is admitted by most writers almost in the same breath in which they advanced them. That which has received the most general acceptinice is the Theory of Aspects, but as an explanation it is incomplete. To say that consciousness is the subjective aspect of matter is equivalent to saying that consciousness is the conscious side of matter, which is no explanation. It is simply stating over again in different terms the fact we wish

1 Mind and Body, p. 196.

2 Physical Basis of Mind, p. 395.

${ }^{3}$ Ibid. 
to explain; and similarly, to say that nerve-motion is the objective a-peet of the same matter is simply to say that nerve-motions are objective phenomena, which is what we lnew before. These are only restatements of the facts, not explanations of them. Nor does it help matters to say that the same matter underlies both, or the difference between them is dne to different modes of apprehending the same thing. I shall have more to say on this point in ehapter iv., to which the reader is referred. What we wish to know is this: How do we come to have two aspeets instead of one? Why, when we have one aspect, should we also have at the same time the other? How is the one set of changes, the physical, related to the other set, the mental? What is that connection between them that insures the presence of a feeling when physical disturbances are produced, or when a feeling is present, induces physical disturbances? What differenee is there between the essential nature of an objective fact, like a neural tremor, and a subjective state or feeling, and have they anything in common? These are important questions which call for answers, and any doctrine which fails to explain them falls far short of the requirements of the case. But these questions, there need be no hesitation in saying, neither the theory of functions nor aspects explains. On the contrary, the former has led to deductions which, though bogically drawn from the premises, are inconsistent with the facts established by each one's own conscionsucss. Consequently the premises must be false. The deductions I refer to I propose to consider in a later chapter, and therefore that discussion will not be anticipated here, further than to say that, 
accepting this explanation, it has been held by some, that states of consciousness are merely by-products, and in nowise essential to the working of the borly; or, in other words, that our feclings have no cansative influence in the production of our actions. So that when I eat because (as I suppose) I am hungry, or work out an intricate mathematical problem, or strike some one who made me angry, I am not prompted to these acts, and do not earry them into execution under the direction of my thoughts and feelings, but these acts are done by the mechanism of the brain, and the chemical and physical changes which work the mechanism are simply accompanied by my feelings and thoughts, but not influenced in any way by them. Our feelings become simply indicators, like those of a steam-engine, which tell the number of revolutions, and height of. pressure, without in any way affecting the revolutions themselves.

Such a conchusion is sufficient to reduce the whole theory to an absurdity.

'The inadequacy of the above explanations, however simple and satisfactory they may appear at first sight, is recognized on all sides, and is the same whether it be approached on the physical or on the subjective side. They simply avoid the difficulty, they do not remove it. 'This difficulty is, as I have said, in explaining how we come to have two aspects, and how these two "aspects" are related; how physical clanges become translated into the subjective feeling. That the two are correlated in time, that is, that the two ocenr simultancously, side by side, is plain enongh and easily understood, but it is confessedly not so easy to understand how the one be- 
comes "transformed" (?) into the other; how, in fact, a feeling insures the presence of a physieal motion, and a physical motion, of a feeling. Thus Mr. Spencer, who, as a psyelologist, has treated the matter in a masterly mamer, maintains this view of different aspeets. "For what," he says, " is objectively a change in a superior nerve-centre is subjectively a feeling, and the duration under the one aspeet measures the duration of it under the other." 1 And the same thing is repeated in other passiges. But this is no explanation, as Mr. Spencer himself tacitly recognizes when he later adds, "though accumulated observations and experiments have led us by a very indirect series of inferences to the belief that mind and nervous action are the subjective and objective faces of the same thing, we remain utterly incapable of seeing and even of imagining how the two are related. Mind still continues to us a something without any kinship to other things; and from the science which diseovers by introspection the laws of this something, there is no passage by transitional steps to the seiences which discover the laws of these other things." ${ }^{2}$ Here is a mystery which he recognizes in common even witl his spiritnalistie opponents.

Professor Tyndall, as a physicist and avowed materialist, as one who finds in the properties of matter alone sufficient to account for everything in the universe, both for the objective phenomena about us, and for the suljective world of conscionsness within, "bows

1 Principles of Psychology, 2d ed., ii. p. 107.

2 Ibid., p. 140. The italics not in original. $b$ 
his head in the dust before that mystery of the mind, which has hitherto defied its own penetrative power, and which may ultimately resolve itself into a demonstrable impossibility of self-penetration." 1 While Professor Tyndall finds in matter alone sufficient to account for the existence of mind, he still recognizes the difficulty whereof we speak. "The passage," he says, "from the physics of the brain to the corresponding facts of consciousness is unthinkable. Granted that a definite thonght, and a definite molecular action of the brain, occur simultaneously: we do not possess the intellectual organ, nor apparently any rudiment of the organs which would enable us to pass, by a process of reasoning, from one to the other. They appear together, but we do not know why. Were our minds and senses so expanded, strengthened, and illuminated as to enable us to see and feel the very molecules of the brain ; were we capable of following all their motions, all their gronpings, all their electric discharges, if such there be; and were we intimately acquainted with the corresponding states of thought and feeling, we should be as far as ever from the solution of the problem: How are these physical processes connected with the facts of consciousness? The chasm between the two classes of phenomena would still remain intellectually impassal,le." 2 "We may think over the subject again and again ; it eludes all intellectual presentation; we stand at length face to face with the incomprehensible." 3

It may be seen how insufficient is the boasted modern

1 A pology for the Belfust Address.

2 Scientific Materialism in Fragments of Science, p. 420.

3 A pology for the Belfist Address. Same, p. 560. 
scientifie doctrine as explained by Spencer and others, even to those who maintain it, by turning to the works of Mr. Fiske, a disciple and enthusiastic admirer of Mr. Spencer. "Henceforth," he says, "we may regard materialism as ruled out, and relegated to that limbo of crulities to which we some time since consigned the hypothesis of special creations. The latest results of scientific inquiry, whether in the region of objective psychology or in that of molecular physies, leave the gulf between mind and matter quite as wide as it was judged to be in the time of Deseartes. It still remains as true as then, that between that of which the differential attribute is thought and that of which the differential attribute is extension, there ean be nothing like identity or similarity. Although we have come to see that between the manifestations of the two there is such an unfailing parallelism that the one group of phenomena can be correctly described by formulas originally invented for deseribing the other group, yet all that has been established is this parallelism." 1

Many other writers, physiologists and psychologists alike, might be quoted to the same effect, but it is hardly necessary.

It is naturally with considerable hesitation that one attempts to explain that which such thoughtful minds declare to be inexplicable, and vet it may fairly be questioned whether, after all, this "mystery" is not a - dust of their own raising. It may be asked whether each, the physiologist and psychologist, has not approached the subject too much from his own point of

${ }^{1}$ Cosmic Philosophy, vol. ii. p. 445. 
view to the exclusion of that of the other; whether the physiologist has not paid too strict attention to the pliysical phenomena to the neglect of facts of consciousness, while the psychologist has kept too steadily in mind the data of consciousness and left ont of sight the physical side. I wonld not be understood to insinmate that either took no account of one or the other side. This would be merely presumptnous misstatement. On the contrary, both recognize one material basis for both classes of facts; both recognize that the presence of consciousness cannot be disassociated from the physical changes which are supposed to accompany it, and that we cannot have one withont the other. But after recognizing this, and indeed emphasizing it and insisting upon it, they straightway take leave of one another, and travel in different directions.

When discussing such a subtle subject as the nature of the relation between mind and matter, it is neessary to keep constantly before one both the facts which terms represent and the ultimate analysis of those facts, and to bear the whole of this nltimate analysis constantly in mind. For example, when we speak of a material object we must constantly lieep before us what we really mean by this objcet; we must have before us the notion of a number of sensations or states of our own mind, such as extension, color, hardness, ete., which are commonly, though of course erroncously, located in the object itself; then the notion of the supposed something existing ontside of us, and which is the canse of those sensations; and, lastly, the inferred reaction between the two, by which the latter excite in us the sensations we call properties of the object. Unless the 
whole of this is constantly remembered we are liable to be drawn into fallacies, for it is only in this way that in any given set of phenomena that which is subjective can be picked out and separated from that which is objective. In the simplest example of the oljective world, as of a table or book, that which is suljective, and the ereation of the mind is so interwoven with that which is objective, and which really exists outside of us, that only those learned in such matters can distinguish between them. Nine persons out of ten, if told that those physical characteristics which distingui-h one picture from another-the beauty of the coloring, the grace of the drawing, and the "tone"-do not really belong to it, but exist as such only in the mind of the observer, would indignantly repel your insinuittions, and if you still insisted upon it as a philosophical truth, you would be set down as a "crank" for your superior knowledge. Even the most acute thinkers, those most conversant with these truths, will sometimes fall into the pitfall of objectivity. Alexanter Bain, for 'xample, in chapter vi. on the Union of Mind and Body, remarks,-

"Walking in the country in spring, our mind is occupied with the foliage, the bloom, and the grassy meads,-all purely objective things; we are suddenly and strongly arrested by the odor of the May blossom; we give way for a moment to the sensation of sweetness: for that moment the oljective regards cease; we think of nothing extended; we are in a state where extension las no footing; there is to us place no longer." 1

${ }^{1}$ Loc. eit., p. 135. Italies not in original. 
Now why is the sense of smell any less objective than the sense of sight? When we smell anything, how does the subjective element enter into it any more than it does in our mental condition when we see anything? The odor called sweetness is as much objective as those sensations of sight which he calls "the foliage, the bloom, and the grassy meads." Sweetness is not extended to be sure, but that is simply because smell is not sight or touch. Sweetness is a sensation which we commonly ascribe to objects, such as a rose or an orange, and we say that it belongs to them as a property, and hence is objective. ${ }^{1} \quad$ Further, though sweetness is not extended, that which causes the sensation of sweetness is capable of being presented to us through the sense of vision, ideally or actually, and then becomes extended.

Perhaps the principal reason for the great hostility which the materialistic doctrine has evoked on all sides is to be found, as has been hinted above, in the deductions which some writers have seen fit to draw from it. Because mind is only a "manifestation of matter" it has been maintained in some quarters that consciousness plays an unessential part in our cerebral processes,

1 It may be urged in objection that the pleasurable emotion acempanying the odor, being entirely a subjective state, eliminates the objective element from the whole. But this would be equally true of the sensations of sight, sweh as "the foliage, the bloom," etc. There is nore of a subjective element ahout sight than smell, for a visual pereeption of an oljeet is a compound sensation, made up of color, absence or presenee of light, size and shape (extension), and the combining of these into an idea of the object is a process of judgment,-an entirely subjective state. 
and has nothing to do with determining our actions. No less an authority than Professor Huxley has expressed the opinion that the "consciousness of brutes [and men] would appear to be related to the mechanism of the body simply as a collateral product of its working, and to be as completely without the power of modifying that working as the steam-whistle, which accompanies the work of a locomotive-engine, is without influenee upon its maehinery." The leeture in which he gave expression to this view exposed him, in consequence, to a storm of vituperation and abuse, which might have overwhelmed a less fearless and able man than Professor Huxley. That this conelusion should not be aecepted is proper, because it is not in accordance with the facts, and therefore either the premises or the reasoning by which it was reached must be false. In this case I conceive it to be the premises. I shall refer to this point in a later chapter and in another connection. But, on the other hand, it must be allmitted that these views are the logical deductions of that doctrine which represents matter and mind to be double but parallel properties of matter. In this context it will be interesting to notice how the same idea of double properties impregnates the thought of another virurous thinker, Mr. Tyudall. He recognizes two difficulties, two alternatives, neither of which ean he accept. He consequently "bows his head" in his acknowledged ignoranee before "two incomprehensibles." The error is the same; it lies partly in his premises, and partly in not keeping in mind what is subjective and what is objective in the notion of motion. $\mathrm{He}$ says,- 
"The discussion above referred to turns on the question, Do states of consciousness enter as links into the chain of antecedence and sequence, which give rise to bodily action and to other states of conscionsuess, or are they merely by-products, which are not essential to the physical processes going on in the brain? Speaking for myself, it is certain that I have no power of imagining states of consciousness interposed between the molecules of the brain, and influencing the transference of motion among the molecules. The thought 'elules all mental presentation,' and hence the logic seems of iron strength, which claims for the brain an antomatic action muinfluenced by states of consciousness. But it is, I believe, admitted by those who hold the automatic theory that states of consciousness are produced by the marshalling of the molecules of the brain; and this prorluction of consciousness by molecular motion is to me quite as unthinkable as the production of molecular motion by consciousness. If, therefore, unthinkability be the proper test, I must equally reject both classes of phenomena. I, however, reject neither, and thus stand in the presence of two incomprehensibles instead of one incomprehensible." 1

The difficulty lies here: if physical changes and consciousmess are double and parallel properties, then, as the former is known to enter as a link in the dynamic circuit, the latter cannot, and must, therefore, be a by-product, withont influence over onr bodily actions. On the other hand, the conscious property cannot be

1 Apology for the Belfast Address. 
thonght of as entering into the dynamie eirenit, becanse of the error above insisted "pon of confusing the subjective side of the notion of molecules with the real objective or unknown side, the molecules-in-themselves. This fallacy pervaldes the whole palsiage.

Even Bain has this idea of a double property. "The only tenable supposition is that mental and physical proceed together as undividerl terms." (This is not an explanation; it is only a restatement of the association of mental and physieal statcs.) "When, therefore, we speak of a mental cause, a mental agency, we have alwirs a tuco-sided cause; the effect produced is not the effect of mind alone, hut of mind in company with body. That mind should have operated on the body is as much as to say that a two-sided phenomenon, one side being bodily, can influence the body; it is, after all, body acting "1mon hody. When a shock of fear paralyzes digestion, it is not the emotion of fear in the abstract or as a pure mental existence that does the harm; it is the emotion in company with a peculiarly arcited condition of the nervous. system; and it is this condition of the brain which deranges the stomach." 1

Now, on the contrary, we are entitled to believe that our mind does not deceive us in this respect, and that it is the sensation of fear which deranges the stomach. How it dues it is another question, but that it does it is beyond dispute. When, at the thought of something disagreeable, we feel natusea and the stomach "rebels," I believe we are entitled to maintain that the disagreeable thought is the eause both of the namsea and the

1 Mind and Body, p. 131. Italies not in original. 
spasm of the stomaeh. When, at the thought of a delicious morsel, our "month waters," it is the thought itself, par excellence, which canses the flow of saliva. But how is the problem requiring solution. I do not think any one ean read Mr. Bain's work withont believing that his treatment of this part of the subject is vague and unsatisfactory.

One thing must be armitted as a logical consequence of this doctrine. If consciousness and neural processes are only collateral parallel phenomena, the former must be excluded from all part in that working of the body in which the latter enter as links in the cireuit of neural undulations.

The difficulty is we have been looking too much through prismatic spectacles, and have seen one line as two.

Sufficient has been said to show not only how inadequate is the commonly accepted modern doctrine to explain the relation between mind and matter, but that this very doctrine, when carried to its logical consequences, leads to the denial of the truth of that conviction possessed by each one of us, that our feelings have something to do with the production of our actions. They become merely collateral products of the workings of the body.

But there is one writer to whom I wish to call attention, who for clearness of thought, precision of expression, and for correct use of terms has rarely been equalled by any writer on this subject. I refer to the late George H. Lewes, whose work on the Physical Basis of Mind has not received, at least in this country, the attention it merits. I know of no one who has so 
correctly appreciated the nature of the problem to be solved. To Mr. Lewes belongs the credit of being the first to offer an explanation of many of the difficulties of the problem; in explanation which in some respects must be aceepted as final. And yet his conelusions I eamnot acept, believing them not to be the logical outcome of his arguments. He maintains the view of difference in "aspects" which hats alrearly been referred to. This, I lope to show, is not a logical or adequate explanation. I cannot at this time refer more particularly to his argument, as it would be anticipating what will necessarily follow.

In the next chipter we shall consider the nature of the problem to be solved and the difficulties surrounding it.

1 I regret that I should have overlooked the writings of the late Professor Clifford on this subject. It was not till a short time before going to press, and some years after this work was written, that I became aware of his essay, entitled "Body and Mind" (Lectures and Essays). The essay just referred to, together with two others on the sume subject, "Things in Themselves" and "The Unseen Universe," are mateppieces of lucid exposition. Professor Cliflord, whose death was such a loss to the world, possessed to a rare degree the faculty of both clearly conceiving what he wished to say, and saying it in at hapy way that was at onee floroughly intelligible and attractive.

I rejoice to say that the views of this rigorons thinker on the question of the relation between Mund and Body agree with those expressed in this work. He is the only writer so far as I know whose views coincide with those herein alvanced. I regret that I am prohibited from referring more particularly in the text to his writings. 


\section{CHA P T ER II.}

THE TRUE NATURE OF THE PROBLEM TO BE SOLVED.

Having now become familiar with that doctrine which has been most generally accepted by those best qualified to judge, and having seen how far short it falls of explaining the connection between those activities we call mental and those activities we call physical; nay, having seen that it has even been declared that "the task of transcending or abolishing the radical antithesis between the phenomena of mind and the phenomena of motions of matter must always remain an impracticable task. For in order to transcend or abolish this radical antithesis, we must be prepared to show how a given quantity of molecular motion in nerve-tissue can become transformed into a definable amount of ideation or feeling. But this, it is quite safe to say, can never be done;" ${ }^{1}$ having become conversant with all this, we shall now proceed, refusing to accept this verdict, to attempt the task; with what success we shall leave to the reader to determine.

I shall state at the ontset that theorem which $I$ conceive will answer all the requirements of the case and which it shall be my effort to prove.

It is this: instead of there being one substance with

${ }^{1}$ Fiske's Cosmic Philosophy, ii. p. 442. 
two properties or "aspects,"-mind and motion,-there is one substance, mind; and the other apparent property, motion, is only the way in which this real substance, mind, is apprehended by a second organism: only the sensations of, or effect upon, the second organism, when acted upon (ideally) by the real substance, mind.

This may, at first sight, appear to the reader as practically the sane thing, only expressed in different terms. But it is not so. There is a radical difference in the conception. The one recognizes one substance with duality of "properties" or "aspects;" the other, one substance with one aspect only. If the meaning of this, at this time, be not clear or be not admitted, I must ask the reader to suspend his judgment, and to follow me with open-mindedness through the next chapter. If it shall then be found that this theorem both explains all the difficulties we have encomntered and does not lead to conclusions inconsistent with the facts, I shall consider that $I$ am justified in my reasoning.

In this problem we have to do with the relationship between two worlds which are consirlered to be radically antithetical in their nature,- - the world of thought and feeling, and the world of things. The former is caller subjective, the latter objective. It will be necessary before going further to inquire more intimately into what we mean by each. This inquiry will necessarily involve what will probably be judged by those learned in the matter a tedions restatement of first principles, but it is absolutely necessary for a proper appreciation of the argument for those not well versed 
in philosophic matters. Therefore no apology will be offered for the digression.

The subjective world is well known to every one. We all know what a thought is, or an emotion of fear, or anger, or a sensation of pain or sweetness. No definition can make the knowledge any more definite. But the objective world about us is not so well known to us. He who imagines that the things about him in the room - the chairs, the table, the pictures-are really what they seem, is grievously mistaken. He who picks up a book, and, perceiving something which has a certain shape, size, hardness and color, say redness, and thinks that these qualities reside as such in the something he calls a book, does not know what perceiving a thing consists in. Physiology teaches us that the qualities of any object, as the book, are only a number of sensations, and accordingly states of our own conscionsness. These sensations we are in the habit of projecting outside of us, and then imagining they exist as such independent of our own consciousness; but as a matter of fact they do not exist as such. When these sensations occur grouped together in a particular way, we call the group, after being thus imagined to exist outside our minds, an object. Each sensation then becomes a quality of the object which is the whole group.

The object, then, does not exist as such ontside of us, but is only a bundle of our sensations. Undoubtedly something exists outside of us which is the cause of these senations in us. This something has been called the thing-in-itself, but its nature is unknown to us. If this is not clear, perhaps an example will make it 
so. We are looking at the question now entirely from a physiological point of view. When I say that my pipe is yellow, I do not mean that there is anything like yellowness existing in the pipe-itself, but the rays of light reflected from the "pipe" fall upon the retina, and a commotion is excited among the fibres of the optic nerve. 'This commotion is conveyed to the brain, and there, in some way or other (which it will be our olject to explain later), the sensation of yellowness is created; so that the quality of yellowness exists in the mind of the observer and not in the pipe itself. All the other qualities of the pipe may similarly be resolved into states of our own consciousness, as, for example, hardness, shape, etc. It is only after we have imagined these sensations to exist outside of us that we can regard the pipe to exist as a pipe at all. But after we have abstracted these qualities from the "pipe," what remains behind? We have every reason to believe that something, which we may call the thingin-itself, exists independent of our consciousness. What this is is another question, which is far beyond our purpose to ronsider here. We may simply say that there are certain activities existing outside our consciousness, which correspond to certain modes of our conscionsness, and constitute the reality of the latter when these are projected ontside of us to form phenomena. The mature of these activities is practically unknown to us. The only thing we know is onr sensations. The material worde is thus resolved into ecrtain mnknown activities and certain groups of sensations, which latter constitute our pereeption of the former.

That these aetivities, constituting the thing-in-itself, 
exist at all is an inference, but an inference of such irresistible force that we cimnot resist it. Thus, the properties of objects are all sensations dependent on unknown activities outsile of us. When these activities exist grouped together in a particular way, so as to produce a particular group of sensations, we call this group a book, or table, or chair, and artificially locate the sensations in the external matter as its qualities. These activities in matter, which may be said to constitute matter, are unknown, and should be denominated simply by $X$.

The application of all this will soon become apparent, if it is not so already. 'That which we call the subjective world is composed of our thoughts and feelings; that which we call the objective world is a mass of activities unknown to us, but conventionally designated by subjective terms of sensation, as red, hard, sweet, etc.; and these sensations are the reaction of the oiganism to these external unknown activities.

Now to extend this reasoning to the same conditions, but submitted to a fiurther analysis, what do we mean by motions, undulations, and such phenomena? On analyzing light by physical methols we find it to consist of oseillations of molecules of the ether. We find that difference in the color of light is due to a difference in the length of these oscillations; that in rel light, for eximple, the length of oscillation is 0.0000271 inch, and blue light 0.0000155 inch, or a little over half as long as that of the red. Somd is said to be due to vibrations of the atmosphere, and the pitch of any note lepends upon the rate of vibration of each particle of air, the greater the rapidity of the vibra- 
tions the higher the note, and vice versa. Heat is said to be motion among the molecules of matter,the more rapid or violent the motion the greater the heat.

Now what is meant by all this? Is there anything really existing outside of us identical with these motions? Do these motions or vibrations really exist as such outside of our own mind? Have, in fact, the oscillations of the ether any more real objective existence than red light or green light? Not at all. We have simply made the really existing, but unknown, activities in matter impress us throngh different channels; made them appear as motion instead of color; made the disturbances of the atmosphere appear through the sense of sight instead of hearing,-as motion instead of sound; made heat appear through the sense of sight instead of touch,- - as motion instead of heat. But the new sensations have no more real objective existence than old and familiar ones. These phenomena have simply been translated from terms of one sense into those of another. Color, somul, and heat have now ceased to be such, and have become motion. These activities can be male by suitable devices to appear to us through several senses; but we must never lose sight of the device, nor of the unknown nature of the activities.

When we talk about matter, then, what do we mean? We may have four different notions, each radieally distinct, and muless we bear constantly in mind to which we refer we are liable to be led into confusion of thought.

1st. There is the notion we may have of our own 
conscious states. As such without reference to any thing beyond them, and consisting of groups of sensations, as of the motion of two points (which points may again be resolved into sensations,-color, shape, etc.). This motion may be called subjective matter.

$2 \mathrm{~d}$. The notion of the unknown reality, or thing-initself, existing outside of us, and corresponding to these seusations, - the unknown $X$. This may be called actual matter.

31. The double notion of both these two classes of facts and the relation between them. This embraces the other two, and is the one which should be particularly kept in view when inquiring into the ultimate nature of things.

4 th. The common idea of matter as employed in ordinary discourse and in the physical sciences. In this sense, matter is made to include onr conscious states (1st notion) after being projected outside of us, and artificially made to have an active existence as phenomena or objects. This may be called phenomenal matter. This, as has already been explained, is philosophically an erroneous notion, being only an artifice, but nevertheless one that is necessary for the ordinary purposes of social life and the pursuit of the physical sciences. Here it is of inestimable value, and, in fact, we could not do withont it. It wonld be ricliculons, not only in the every-day use of language, but in our conceptions employed to carry on the ordinary affairs of life, to bear any other notion in mind.

In discussing philosophical matters, however, it should always be remenbered that it is only through an artifice, as Lewes has pointed ont, that we have this 
conception; lut it is an artifice that is indispensable when properly employed.

Now in these different notions embraced by " matter" lies the gist of the whole question under consideration. These are facts which even Macaulay's wonderful sehool-boy onght to know, though it is to be feared that his elucation has been sadly neglected in this respect. Certainly every one who has discussed the subject since Burkeley wrote knows them, and yet we continually gro on talking about "matter" as if it were perfectly plain what we meant, and it were impossible to misunderstand which of the four notions we had reference to. We take the preciution to analyze the meaning of the term in a sort of prologne to our arguments, discover that it covers at least four different classes of facts, insist upon the importance of the discovery, and straightway apparently forget all about it when we happen to require the term for use. I do not think I speak too strongly in saying that it too often happens that we use the word "matter" regardless of the varions interpretations that may be placed upon it, and I venture to say that nine times out of ten, even those who are the most precise in the use of terms, will speak of matter withont regard to its being an abstract term, and withont proper weight being given to the different facts embraced by it. If interrupted in the flow of their talk, they will with great accuracy explain what we know, but in argument the worl is used in the most general manner. Hence often difference of opinion arises simply because of the shifting meaning given to the terms employed. Of course, in speaking in this way of the ambiguous use of this word, I 
refer only to philosophical discussions. In the physical sciences the term is employed with a special signification, and is well understood.

Let us return now to our subject, and apply what bas been learned regarding matter to the motions of the cerebral molecules which are said to accompany consciousness. It is evident that in speaking of the molecular motions occurring in your brain I may refer either to the motion proper, which is my state of conscionsness, or I may have reference to the reality actually occurring ontside of me and belonging to yon, and a part of you. If I refer to the former, I know what it is; it is my sensation. If I refer to the latter, the Reality, the question arises, What is it? Is it unknown, and if not, what is its nature? We will approach this question in another way, which will make its meaning clearer.

Let us consider these physical cerebral activities, and ask from a purely physical point of view what kind of activities they are. We have reference, of course, only to those activities which are supposed to constitute nerve-force and to underlie all conscions states. Suppose that by a suitable device we could have them presented to us objectively, so that we conld actually recomnize them, how would they appear to us? That would depend upon the sense we employed in perceiving them. We might ideally (as we do when thinking of them) or actually see them; they woukd then appear as motions, oscillations, undulations, or some such movement. We might, by the suitable microphone, hear them; they would then appear as musical notes. If our tactile sense were sufficiently 
developed we might feel them; they might then appear as heat. But none of these sensations represent these activities as they really are.

Now, to put another hypothetical question, suppose, for a moment, that what they really are is eonseiousness,-that is, a thought or sensation of pain,-how would this sensation of pain appear to us if we could apprehend it through our senses, and through the sense of sight in particnlar (either, of course, ideally or in the brain of another)? The answer is, Only as all other activities in matter appear to us, namely, as motions, undulations, ete. If, then, these hypothetical conditions were the facts, it would be easy to mnderstand how mental states can beene "transformed" into physical disturbances, and vice versa, because there is no transformation about it. There would be in this case only one thing, mental states, which would appear as physical activities when vicued (ideally) through the scuses, as tremors if riewed through sight. Now have we any reason for believing that the actual activities-these physical activities-in-themselves, as they really areare a state of conseiousness? This it shall be our effort to establish by a series of inferences, the only method of proof open to us for such a problem. If we are successful, it would appear that the reason for the difficulty which has been experienced in conceriving how a sensation can become a plussical change lies in not properly pereiving the nature of the problem we are trying to solve. A great deal of thonght has been devoted to trying to understand how moleculin changes are transformed into consciousness, when in reality there is no transformation at all. Another sonre of error has 
arisen from regarding the two classes of facts-the physical and the mental-as two different modes of apprehending, or aspects of the same thing. An artificial parallelism has thus been drawn between them which has only served to increase the diffienlty, and has prevented all assimilation of one with the other. To this parallelism so much attention has been devoted that the mode by which the parallelism arises has been neglected and an artificial difficulty created.

To show how much stress has been laid on this parallelism and to what diffienlties it leads when pushed to an extreme degree will require a momentary digression. That a parallelism exists is true, but it has been exiggerated into a great bugbear, because there has not been constantly and elearly kept in mind what is parallel. Phenomena have been made abstractions, abstractions unconsciously made entities, and two lines shapply drawn parallel, which originate and diverge from the same puint.

To justify this assertion I shall refer to a very able writer, from whom I have had oceasion to quote before. "On snch grounds as these," says Mr. Fiske, "I maintain that feeling is not a product of nerve-motion in anything like the sense that it is sometimes the product of heat, or that frietion electricity is a produet of sensible motions. Insteal of entering into the dynamic circuit of correlative physical motions, the phenomena of conscionsness stand outside as utterly alien and disparate phenomena. They stand outside but uniformly parallel to that segment of the eirenit which consists of neural undulations. 'The relation between what goes on in eonseionsness and what goes on simultane- 
ously in the nervous system may best be describerl as a relation of uniform concomitance. I agree with Prof. Huxley and Mr. Harrison that along with every act of consciousness there goes a molecular change in the substance of the brain, involving a waste of tissue. This is not materialism, nor does it alter a whit the position in which we were left by common sense before physiology was ever lieard of. Everybody knows that so long as we live on earth the activity of mind as a whole is accompanied by activity of the brain as a whole. What nervous physiology teaches is simply that each particular mental act is accompanied by a particular cerebral act. By proving this the two sets of phenomena, mental and physical, are reduced each to its lowest terms, but not a step is taken toward confounding the one with the other. On the contrary, the keener our analysis the more clearly does it appear that the two can never be confonnded. The relation of concomitance between them remains an ultimate and insoluble mystery." I

Let us see how much truth there is in all this. On examining the passage critically it will be found to contain three distinct propositions : first, that states of mind are phenomena; secondly, that states of mind, as feeling and neural molulations, are "utterly alien and disparate in nature;" thirlly, that the relation between them is only one of parallelism and " uniform concomitanec." Each of these propositions will require separate consideration.

1 North American Review, Jan.-Feb., 1878. The italics are mine. 
To the first we will devote only a few words in this place, as it is liable to involve us in a discussion regarding terms merely.

It may very properly be questioned whether states of mind recognized as subjective can be designated by the same terms used to characterize the physical world. If the former are actualities, as I hope to be able to show strong grounds for believing, and the latter merely symbols of something else, then, though the latter are properly classed as phenomena, or the appearances of things, the former should be classed as the thing-in-itself, or actuality, and not phenomena. To insist upon this exactness in the use of terms may appear to the reader to savor of pedantry. But it is not so. Though it may be of no consequence what terms we use so long as we bear continuously in mind the exact conditions which they represent, still it is almost impossible for even the clearest thinkers to keep the thing represented differentiated mentally from the terms representing it, and in the prolongation of an argument the two become unconsciously confused; so that, though the premises may be exactly defined and true, in the conchusion and especially in corollaries and deductions drawn from these conclusions, crrors of great magnitude and serious moment creep in. Just as a slight error at the apex of an angle may be of no consequence, yet with every prolongation of the sides the error becomes amplified. So it is with philosophic discussion. The history of philosophy has been the history of the misuse of terms.

As to the second proposition, that the "phenomena" of conseiousuess are "utterly alien and disparate" from 
the phenomena of physical motions, it must rest upon either one or two alternatives.

We have seen before (pp. 30-34) that physical motions have no objective reality or existence as such outside of our own minds; on the contrary, they are suljective sensitions, similar to any other mental state, thongh they be caused by some physical change in actual matter, and of which they are the symbols. Consequently, being subjective, so far from being utterly "alien and disparate phenomena," physical motions and mental states are of exactly the same nature and class. If to this Mr. Fiske replies, as he undoubtedly would, that he takes the other alternative, and means by "physical motions" simply to symbolize the unknown plyysical disturbances of which motion is only a subjective representation, - as he must eall them something,-then I answer that he clearly hegs the question in asserting that they are "ntterly alien and disparate ;" for, as lie confesses that he does not know and cannot know what these unknown plyssical changes really are, he cannot logically assert whether they are or are not essentially similar to or different from the "phenomena" of conscionsmess. If we do not know what they are, what right has any one to declare that both may not be of the same nature; or, at least, do so without strong eircumstantial evidence in faror of such a conchusion? But no attempt has ever been made through indirect evidence to establish this conclnsion. On the contrary, everything points the other way. To assert without cireumstantial evidence that the two classes of phenomena are essentially different, is like maintaining that any object whatever, as this pen with 
which these lines are written, has no resemblance to any other object lying at the bottom of the sea, when we have no idea whatsoever of the object that is lying there, or any knowledge of the conditions by which it came and remains there. Nor can I reconcile this passage with his approval. of that portion of $\mathrm{Mr}$. Spencer's argument quoted on pages $446-148$, vol. ii., of his "Cosmie Philosophy."

It is absolutely essential that we should bear in mind at the outset that the physical changes which go along with every act of conscionsness are in reality not an undulation or a motion, but an unknown $\times$.

This oversight, which it would appear to be, seems to have arisen from too close attention having been paid to the third proposition, or the parallelism and concomitance of the phenomena. That the two classes of facts are parallel there can be no donbt; that they are concomitant there can be no doubt. The same thing may be said of the musical note and the vibriltions of the tuning-fork. 'They are parallel and concomitant; but coneomitance is not the sole relation. No one would think of confusing visual vibrations with a musical note; the contrast between them is slisrl and defined. So no one can confuse a feeling of pain with the oscillation of a molecule; they are sharply contrasted; but it may be shown that one is only a mode of eognizing the other, or rather, the former is the actual activity, the latter the mode by which a second person becomes conscions of its existence. "Can we, then, think of the subjective and objective activities as the same?" asks Mr. Spencer. Looking at them simply as activities, and not as phenomena, I 
unbesitatingly answer, "Yes, we can." "Can the oscillation of a molecule," he eontinues, "be repr"sented in conscionsness side by side with a psychical shock and the two be recognized as one? No effiort enables us to assimilate them. That a unit of feeling has nothing in common with a unit of motion becomes more than ever manifest when we bring the two into juxtaposition." Mr. Spencer has here misconceived the nature of the problem he is investigating. Such a question is like asking is a stone a tree, or is sound light.

Whatever view he held regarding the likeness or unlikeness of the activities called feeling to the activities underlying the phenomena called a table, we have no reason to believe they are unlike those activities underlying the phenomena called neural undulations, however different they may be made to appear by artificial means.

If this reasoning be correct, the inference is justifiable that too much attention has hitherto been paid to the phenomena themselves and too little to the activities lying behind them. It must not be inferred from anything that has been said in these pages that any of the writers quoted have not recognized the great truths established by Berkeley regarding the amount that is subjective in that which we call matter. On the contrary, in the pages of Fiske and Speneer and others they are reiterated over and over again. But having been once reeognized, they atre straightway overlooked on being put into applieation. This will be considered by some an muwaranted atsertion, but I believe it to be borne out by the facts. 


\section{CH A P TER I I I.}

THE SOLUTION.

We shall now inquire into the grounds we have for the suspicion that states of mind and neural activities are identical, and if it shall be found that the evidence is sufficiently strong to turn this suspieion into a conviction, we shall proceed to an investigation into the conditions which cause them to appear so strongly eontrasted.

The method which we shall employ will be the physiological method, as being the one most conducive to positive results; but the conclusions arrived at will then be submitted to the test of subjective analysis; and if they shall stand this test we shall consider that our theorem has been cstablished.

There are two propositions the acceptance of which is absolutely essential for any discussion of the problem on which we are engaged. These are: first, every state of consciousness has its seat in the brain (or at least in some part of the cerebro-spinal system); and, second, every such state is accompanied, as has becn so frequently stated above, by a molecular change in the substance of the brain. The first of these has been so well established that it would be tedious to repeat the proofs of it here. The second has also been aceepted on all sides by spiritualists and materialists alike. They may both, then, be considered ar outside all matter of con44 
troversy. But now I propose to assume what will not be so readily granted and will even be totally denied by some people; nevertheless we liave a right to assume it if only as a basis of investigation. This is, that not only is every act of conscionsuess aceompanied by a molecular change in the substance of the brain, but that the former is in some way dependent upon the latter, though we may not know how. This is an inference we have a right, from a physiological stand-point, to make. Everything in cerebral physiology points towards it. Everything that points to the existence of these molecular changes and a concomitance of the two classes of facts-the objective and subjective-points to this conclusion. As physiologists we are entitled to employ the physical method and study both classes of facts objectively, and when we to so this conclusion is inevitably forced upon us. It would be carrying us too far out of our way to go into all the physiological facts upon which this reasoning is based ; but they may be summed up in the following brief statements: We can have no eonscionsness withont a material substance, the brain, nor without the activity of the brain. Injure the brain and you destroy conscionsness; prevent the activities from going on and we have no conseiousness. Excite these activities and conscionsness appears. They appear incariably side by side. Alter the conditions of ocenrence of the physical changes and an equivalent alteration occurs in consciousness. Change the quality and quantity of the physical changes by disease and a similar alteration of the quality and quantity of conscionsness appears (delirium, etc.). Increase the intensity and quantity of physical changes 
and a concomitant increase takes place in consciousness. This and much more points to a dependent relation.

The admission of this is not a committal of opinion as to the nature of the dependency. It is consistent even with the belief in a spiritual mind, or with the belief that it never can be discovered how the one class of facts is dependent on the other. Whatever view be held regarding this point, from a physiological point of view the conclusion of dependency is justifiable and sound. To be sure, it cannot be established by positive and direct proof, and it depends upon a series of inferences for its support. But it is not for that reason to be discarded. How many things in this world which are accepted as established facts are anything more than inferences? The foundations upon which the sciences of chemistry and physics rest are nothing but inferences. The boasted atom and molecule are nothing but hypothetical existences. The ether, into disturbances of which light has been resolved, has only an inferential existence. The external world, everything about us, the books, the table and the chairs in this room, the human beings and the horses and carriages that pass the window, all animate and inmimate things, the world and the universe itself, lave only an existence for us based on our inferences. We only know the sensations they produce in us; that there is any matter lying behind these sensations and the cause of them is only an inference, but an inference so strong that no one can deny the truth of it. Furthermore, it is upon a series of inferences similar to those upon which the dependency of mind upon matter is based that half the physiological processes of the body are established. It is 
by means of a similar series of inferences that the livercells are said to seerete bile, the peptic cells pepsin, and the salivary cells saliva. ${ }^{1}$ It must also be borne in mind to what a large extent we are dependent upon inferences for most of our daily acts. We do not hesitate to convict a man and send him to the gallows, even though the verdict which convicted him was based on a series of inferences. It is only upon a series of inferences that the physician establishes his cliagnosis upon which rests the fate of his patient, and upon inferences the merchant and the speculator risk their fortunes.

Yet there are probably those who will deny the validity of the inference that consciousness depends on physical changes being indnced in the cells of the brain. They only see parallel phenomena, with no bond of connection between them. What a mental act is, how it is related, if at all, to the coneomitant molecular change in the brain, is declared to be an insoluble mystery, and they do not advance one iota beyond the point where the question was left by Deseartes over two hundred years ago. How thought can proeed $i n$ variably side by side with physical clange and be uncomnected with it, be neither material nor spiritual, ${ }^{2}$ is difficult to understand. I confess my inability to comprehend such eclectic reasoning. If we touch a lighted mateh to a piece of paper we find it invariably burns,

${ }^{1}$ I hope no one will imagrine, becase a simile is here employed, referring to the logical process, that the physiological process is meant, and the brain be supposed to secrete thought.

"Compare Mr. Fiske's assertion that his views alre "not materialism" with his argument for quasi-spiritualism in "Cosmic Philosophy," vol. ii. part iii. chup. iv. 
consequently we say the cause of the paper burning is the lighted match. Whenever the gastric cells are stimulated gastric juice is formed. We still say that the latter is dependent upon the former. But in the brain a sharp line is drawn. Thongh mental activity is invariably conneeted with cell activity, no dependent relation is admitted by some. It is difficnlt to appreciate the consistency in asserting the one and denying the other. I think we have as much reason in the one case as in the other, so long as we deal with physiological inquiries, in holding that one group of phenomena is dependent npon the other group, though we may not understand how it is so dependent. If one chooses to deny the validity of all causes on the ground that we only know sequence in time, and that the idea of eause and effect is only an abstraction of the mind, all well and good. But if cause is admitted in one case, it must be in the other also. ${ }^{1}$

It is only so long as we study the problem from a physiological stand-point that we observe two processes, - the physical and the mental. The minute we leave physiology we find that there are not two processes, but only one process, and a feeling is not strictly accompatnied by a physical change. This will soon be shown.

There is one anusing thing eonnected with this discussion, and that is the realiness with which those who deny any relationship between the mental and physical phenomena seize upon the theory of a physical substratum to conscionsness and maintain the existence of physical changes "in the substance of the

1 It may be thought that I am arguing against imaginary objections. If so, no harm is done. 
brain involving a waste of tisste," and which "go along" with every act of concionsness." This doctrine they maintain with a eonficlence that is amaring, eonsidering that it is entirely beyond the possibility of so called proof. It is in reality only thenry, and supported merely by a series of inferences similar to those upm which the doctrine maintained here is bared. Neither less nor more. And yet it is commonly stated as if it were an established fiact, entiryly beyond eavil, am that, too, by the very persons who refise to reconnize the firre of a similar process of reasoning to establish a relationship between mental and physical phenomena. But I do not wish to be understood to push the ground from under my own feet. There is every reason to believe that these physical changes do occur, and that they are the foundation of every doctrine of a physical basis of mind. But they camnot be considered as absolutely established, and rest simply on evidence similar to that for the theory advocated in these pages.

To proceed with our argmment. We have two classes of facts, mental and physical; the former we assime ${ }^{1}$ to be dependent upon the latter. The one we know as thought, scusition, and emotion; the other ntterly unknown objeetively, but represented by symbols in eonscionsness. What is the nature of this dependenee? There are four possibilities, and four only, which are thinkable.

First. Consciousuess may be formed, secreted, manufaetured, so to speak, by the protoplasmic activity of

I If any one denies the validity of this assunption, hut admits the rest of my logic, I am amply satisfied. The case is then sufficiently proved.

c $\quad d$ 
the cells of the brain, after the same manner that livercells secrete bile.

Second. Conscionsness may be a change in the mutual relations of the actual or real moleenles of the protoplasm of the brain-cells; that is, these unknown physical disturbances themselves, - the protoplasmic disturbances as they really are; the actuality of so-called neural undulations. It would possibly be equivalent to the passage of the protoplasm from a higher to a lower state of chemical combination, or more probably some physical as opposed to a chemical change, as, say, so-called undulations or vibrations.

Third. It may be the essence or actuality of a second and parallel physical change in the protoplasm. Supposing, for example, the physical change, which enters into the nervous circuit, beginning at one end as irritations, and encling at the other in muscular action, to be undulations in nervous matter, conseionsness might then be the actuality of a second physical change induced by the parallel and conconitant physical change.

Fourth. Consciousness may be the reality of a change induced by the cerebral molecules in a second substance pervading all matter (and therefore the brain), the ether.

A very little consideration will show that the first of these propositions is not only untenable, but may be reduced to an absurdity. It would not be seriously considered here were it not that an expression made use of by a German physiologist has given rise, rightly or wrongly, to the idea that such an explanation has been maintained as a doctrine of materialism. Aceording to this view, every thought must be something 
new-formed, something newly brought into existence. But this something must be either immaterical or material. In the former case, aside from the inconceivable conception of a material substance manufacturing an immaterial or spiritual thing or entity, it becomes necessary to revive the old doctrine of a supernatural or spiritual mind. This in itself is a sufficient objection. I shall have more to say in regard to it later. In the latter case, if this new-formed substance, a thought or idea is a material something, it necessarily follows that this secretion, for such it must be, must remain $(a)$ in the brain; or $(b)$ be removed as such by the natural chamels, the blood-and lymph-vessels; or (c) be decomposed soon after formation, leaving its resulting products to be removed. The objections to, or rather the absurdity of, all these possibilities (or impossibilities) is so obvious, that any serious discnssion of them seems unnecessary. But it is somewhat startling to think of the peril in which the life of any individual, who boasts of an abundance of ideas, would be pliced from the aecumulation of this extraordinary secretion beneath the skull. One can imagine that the effeet would be similar to filling his head with dried peas, and then pumping it full of water. The sword of Damoeles would be a mere bagatelle compared to the danger of his own thoughts. Like a steam-engine without a safety-valve, he would be the generator of the power that would explode himself. While if his ideas and sensations were removed as such, by the vessels, they would be carried away to all parts of his body whithersoever the blood and lympls flowed. We might then be said literally to carry our ideas in our finger-tips, while our 
inner organs would once more be embellished with our emotions and the peculiarities of our character,-a sort of visceral phrenology. We might, with literal truth, be said to have "bowels of compassion," and to have a "heart full of feeling."

The third hypothesis is not so easily disposed of, and yet it will not be difficult to show that it is mutenable. In the first place, it leads to the negation of consciousness as a causative factor in all our action. It makes consciousness superfluous, as everything could be done as well without conscionsness as with it. Consciousness becomes the steam-whistle to the engine. This was shown in the first chapter. It rednces the doctrine to an absurdity.

In the scond place, it is incompatible with the doctrine of the correlation of forces; for, if those physical activities called neural vibrations enter as links in the dynamic eirenit, which begins with the ingoing current and ends with the outgoing current, there is no link left for those activities called mental. (See page 16 , also Chap. V.)

In the third place, it is an unnecessary and superfluous element. If conscionsness conlel be identical with these sceond physical activities, so could it be with the first series of activities. There is nothing in favor of the former that does not speak for the latter, which are included in the second hypothesis.

The fourth proposition, ${ }^{1}$ that mind is the Reality of

I I seareely imagined when this chapter was written, some eirht or nine years ago, that those unlinown activities, represented to us oljectively as the ether, would ever be seriously proposed as an explanation of the nature of mind, and much less 
a molecular change transmitted to the ether, is also one which cannot be maintained. It is open to every objection to which the third is sulject. These objections are fatal to it. As with the second activities so with the ether. We gain nothing by transferring this disturbance to a second substance, about which we know

that the ether in its material aspect would be so made use of. But such seems to have been the ease. Dr. Mandsley, in a work lately published (Body and Will, Kegan, Paul \& Co., 1883), utilizes the ether as a means of bridging over the conventional chasm between mind and matter, and as explaining what mind is. "Perbaps ... the theory of an all-pervading mentiferous ether," he says, "may help to bridge over the difficulty. For if the object and the brain are alike pervaded by ach a byjersubtile ether; and if the impressions which the particular object makes upon the mind be then a sort of pattern of the mentiferous undulations as they are stirred and conditioned within it by its particular form and properties; and if the mind in turn be the mentiferous undulations [italies are mine] as conditioned by the convoluted form and the exceedingly complicated and delicate structure of the brain; then it is plain that we have eluded the imprassable difficulty of eonceiving the action of mind upon matter-the material upon the immaterial-which results from the notion of their entirely different natures. Here, in fact, is a theory that gets rid at the same time of the grom materiality of matter and of the intangible spiritualities of mind, and instead of binding them together in an abhorred and unnatural union of opposites, unites them in a happy and congenial marriage in an intermediate substance,-a substance which, mediator-like, partakes of the nature of both without being exchusively either." The fallacies, only out of respect for Dr. Maudsley's ability I do not say absurdities, of such an hypothesis must be applarent to the reader who has followed me thus far. The fict that such a crute notion could be serionsly entertained by a writer having sueh a special knowledge of the subject as Dr. Maudsley, shows how little understood must be even the nature of the problem with which we are dealing. 
scarcely anything, save a certain amount of nystery, while we break the Newtonian canon, forbidding us to postulate new causes before proving the inadequacy of existing ones. If consciousness can be produced by atoms of ether, in a state of change, why cannot it be - done by atoms of protoplasm under similar conditions? Furthermore, the introduction of a new factor brings with it new difficulties which are quite as troublesome to explain. For instance, it is very diffieult to understand how changes in a homogeneous substance, such as we must understand the ether to be, can give rise to the multitude of heterogeneous ideas and sensations of which the human mind is possessed, unless there be a different kind of change for every species of mental progress; a most improbable, if not impossible, assumption. But, supposing it to be the case, these heterogeneous distrubances of the ether must be indicated by corresponding changes in the protoplasm of the brain; in which case the ether, from a logrical point of view, would be an entirely unnecessary factor, and henee there is no necessity for introducing it as an element in the problem.

We are left, then, with the second hypothesis, against which none of the objections to the others obtain. According to this, eonscionsuess is the nuknown cerebral activities molerlying the phenomena which we call nenral disturbances or notions. It may be called an alteration in the temporary conditions under which the Realities of the atoms of protoplasm of the brain exist. Conscionsness is the supposed "nuknown" disturbances $X$, which in this case are known to us. It is the actual physical change as it really occurs, not as it appears 
to us objectively. It may be called the essence of physical change in cerebral protoplasm. In other words, a mental state and those physical changes which are known in the objective world as neural undulations are one and the same thing, BUT THE FORMER IS THE ACTUALITY, THE LATTER A MODE BY WHICH IT IS PRESENTED TO THE CONSCIOUSNESS OF A SECOND PERson, 1 -i.e., to the non-possessor of it.

Having arrived at this apparently paradoxical conclusion, the task still remains to us to explain the sole objection which can be urged against it, and this is: How does it happen that cerebral activity or consciousness can be presented to us under such strongly contrasted forms? This will be considered by some persons to be the same thing as the original problem, How physical changes or matter becomes transformed into consciousness; but with the foregoing presentation of the problem it has assumed another aspect. The real question is, not regarding the transformation of matter into mind, but how one state of consciousness comes to be perceived as another state of consiciousuess, or how a subjective fact comes to be perecivel as an objective fact; how a feeling comes to be presented to us as a vibration.

Unless this can be satisfactorily answered, the conclusion at which we have just arrived camot claim acceptance. For this purpose it will be necessary to submit it to subjective analysis, as was promised at the outset; and after this has been done, if we find that

1 It is not sufficiently exact to suy that both are diflerent modes of apprehending one and the same thing, for that implies that neither is the actuality. See Chapter IV. 
there is no real contradiction, we shall consider that our theorem has been established.

For those who are accustomed to think on such matters what has already been said in the last chapter will be sufficient, and they will see at once that there is no real difficulty; but for the majority of readers some further explanation will be necessary.

Whether the explanation which has already been suggested, and will now be offered with more detail, will prove as satisfactory to others as to the writer remains to be seen. The confidence of the writer in its adequacy and correctness is naturally strengthened by the fact that thongh arrived at independently by him many years ago, it is in many points similar to that originally offered by Mr. Lewes, to whom the eredit is due for having been the first to really perceive the true nature of the problem. It almost seems, if the reasoning here employed is correct, as if Mr. Lewes, however, had missed the point of his argument, for he expresses his conclusions in terms which to not seem to the writer to be applicable. He considers the difference between the mental and the physical processes to be one of aspeets, and to be dependent upon the difference in the modes of apprebension. My objection to this mode of expressing the relationship will be given later. The difference between us may be only one of terms; but as Mr. Lewes himself has most rigorously insisted on the necessity of precision in the use of terms, I have less hesitation in calling attention to the distinction. ${ }^{3}$

1 The late Prof. Cliflord is the only writer, so far as I know, whose views on the relation of the mind to matter thoroughly coincide with those herein expressed. 
It may at first sight appear impossible that these physical phenomena, with which we are fimiliar, as motion, undulations, or what you will, can also appear as states of consciousness. But this is becanse in our daily experience we are apt to overlook the well-known fact, which has been sufficiently explaincd in the preceding chapter, that all those properties with which we endow matter have no objective existence, but are only subjective states called sen-ations, and hence forms of conscionsness, and these are symbolic only of the unknown change occurring in matter. Just as the words written on this page are symbolic of the ideas they represent, but are as unlike as possible the ideas themselves. Any sensation, such as light, is a representation in consciousness of physical changes in matter ontside the brain, but gives us no idea what those changes are. A sensation is related to its physical external cause as the dent in the hot iron is to the blow of the blacksmith's hammer that fashions it. The true nature of a physical change in a foreign body-a piece of iron, for example-is absolutely beyond our range of comprehension. A physical change in my brain is an idea, my idlea. To you, could you in some way become conscious of it, it wonld appear only like any other physical phenomenon,--as, for instance, a vibration,-being only symbolized in gour consciousuess; and when you idleally conceive it, it is not the idea itself which yon are conscions of, but the disturbance in your bran in the form of a sensation, and this you characterize as a physical phenomenon, and locate in mine. So that a disturbance in my brain which $\mathrm{I}$ experience as an idlea of an orange, yon idcally experi- 
ence as a physical phenomenon in the form of a neural undulation or some similar (objective) sensation.

Let us take a concrete example. We will imagine that you have a sensation of pain presented to your mind; we will also picture to ourselves a physical process in your brain in the form of neural vibrations. Now these two-the mental and physical-are usually described as two processes, both of which oceur sonehow in you. They are said to take place synchronously, and one is the correlate of the other. But this is not the correct way of putting it. We will suppose now, further, I could apply a microscope to your brain and watch the cells (as I can ideally) when this pain is felt by you. What now would happen? At the moment when you have the sensation of pain $I$ become conscions of neural vibrations, which I locate as such (but erroneously) in your brain-cells. The real activities in you are pain, not neural vibrations. The reason for this is this: your mental process, the pain, acting upon my retina sets up a process in me, and as this process of mine is excited through my organ of vision, I am affected according to the pliysiological laws of this organ and become conscious of neural vibrations. These neural vibrations I crroneously loeate in you while they really are parts of my conscionsness, and the only thing which oceurs in you is the feeling of pain. The reaction of my brain to your fecling is a sensation of vibrations. The only way in which these activities conlel be apprehended by me is objectively as ncural vibrations. The only way in which they can be bronght into your conscionsuess is as the sensation of pain. But, in fact, it is one process in you, the sensation of pain, which is 
the real activity. Here, then, lies the parallelism of the phenomena: your consciousness or pain is the correlate of my apprehension of this consciousness as neural vibration. The parallelism is between your consciousness and my consciousness of your consciousness, or, what is the same thing, between the consciousness in you and the picture in my mind of neural vibrations. The former is the reality, the latter the symbol of it. There is an invariable concomitance of these facts.

Again, under the hypothetical conditions stated above, I cannot become conscious of your physical changes or process in its true form, the sensation of pain, for that which I become conscious of is the effect which this physical process produces in my brain, the reaction of my brain to it, as a sensation of neural vibrations. To be sure, I can eonjure up the sensation of pain by allowing my mind to dwell on it, and produce in this way a so-called imaginary pain; but this is an entirely different thing. In that case there would be no relation between $m y$ mental state of pain and your mental state, which I am endeavoring to become conscious of. So you can picture to yourself neural vibrations as well as $\mathrm{I}$, and perceive them as objective phenomena. But here, too, the conditions are altered, and we have to do not with a mental process and its correlated nomral process, but with a physical process ideally projected outside of your cerebrum, and a symbolic representation of it as neural vibrations in your mind.

It is no objection to this statement of the nature of the parallelism to say that there is something more than a parallelism between your consciousness and my 
mode of becoming conscious of your consciousness, because you can have both consciousness as pain and a picture of neural vibrations supposed to occur side by side with the former, for this amounts to the same thing. For when you conceive of correlated neural processes in your brain you in reality have gone through the following logical process: you first have perceived hypothetical physical disturbances in some one else's brain, and these you have recognized as neural vibrations. Then you have inferred that they occur invariably side by side with the conscionsness of the individual. Having determined this, you ideally abstract them, transfer them to your own brain, and infer that they occur there under similar conditions. This is the same thing as if a second individual had been the object of your study. Then it follows that when you think of physical changes in the protoplasm of your brain you ideally abstract and project them outside of you, and then ideally become conscions of the effect which they produce on your mind, namely, the sensation of vibrations; but this effect is entirely distinct in character from, though correlative with, the icleas which are the realitics.

Plysical changes occurring in a foreign borly, as a piece of iron, though giving us our experience of it, must be absolutely unknown to us. Physical changes oceurring in our brains are clearly known to us; they are our thoughts, our sensations, and our cmotions. 


\section{CHA P'TER I V.}

THE NATURE OF THE MIND.

Fron this point of view it is plainly evident how barren must be the question, What is the ultimate nature of mind? when by it is meant a desire to go behind the facts of conscionsness. The very question involves an absurdity. We all know what mind is by direct consciousness. Mind is mind and that is the end of it. When we step on a needle and feel pain we know what pain is; and if we could resolve it into a dozen physical elements, such as vibrations among those molecules which make up the protoplasm of the brain-eells, it wonld give us no new information on the nature of pain. Those vibrations are not pain, but every one knows what pain is. When we are angry with any one for an injury done us, or feel sorrow at the death of a friend, we know what sorrow and anger are. The mere consrionsuess of these emotions is sufficient. So we all know what the idea of a horse is. When we say these different mental states are molecular vibrations in nervons matter, it is, ans Lewes has well pointed ont, a mere artifice to enable us to study the conditions muder which these states of conscionsness are generated. This artifice is of inestimable value; but the fact must never be lost sight of that it is an artifice, and the artifice must never be con- 
founded with the reality, which is the mental state. When the physicist declares that light is a vibration of the ether, and the chemist that sulphate of iron is green and sulphide of lead is black, both make use of a similar artifice, and endow matter with properties which exist only in their own minds. This is a device which is not only justifiable but necessary for the study of nature and the progress of science. In no other way could we examine the conditions under which phenomena exist, and determine relations of difference and agreement, in which all knowledge of the objective world consists. It is so with the study of mind when we employ the physiological method. When we study mental states as physical conditions we use the physiological method; but when we inquire into the ultimate nature of things, and desire to know more of mind than is furnished by consciousness, we fail to bear in mind what knowing a thing consists in. When we ask what water is, the chemist tells us it is composed of hydrogen and oxygen. But hydrogen and oxygen are not water: it is only when they are chemically united that we have water, and then we have hydrogen and oxygen as such no longer. When we ask what sound is, the physicist says it is the vibrition of air. But have we now any more intimate knowledge of its essential nature? On the contrary, somud is the sensation which is the effect of certain nnknown disturbances in matter acting on our auditory apparatus; and when we describe these disturbances as vilbrations we artificially make them appear to us through sight, and simply transfer them from terms of one sense into those of another. We seem to know 
them better because the sensations of sight are usually more vivid and complex than those of sound. It is the same with heat. Neither sound nor vibrations nor heat are the real disturbances. These must be forever unknown to us. Knowing the nature of a thing, then, in the objective world merely consists in translating the terms of perception from those of one scnse into those of another, or into different terms of the same sense. How, then, can we have a more intimate knowledge of the nature of mind by saying it is neural vibrations? We might, by means of an extraordinarily delicate microphone, listen to the num mur of the molecules as they jingle against one another in the myriads of cells of the brain. In that case it might be said that mind was a musical note. Actual feeling is not molecular vibration, though it may be presented to our sensès as such; but there is no objection to our using physical terms to describe states of conscionsness if we keep in mind the object we have in view, any more than there is to the physieist's using terms of sight to describe phenomena of sound. In hoth cases they answer the same purposes.

But further, let us suppose that these plyysical disturbances could be shown to be vibrations in nervons protoplasms, and that we could actually see them under the mieroscope. Wonld we now lave any better knowledge of the ultimate nature of mind than at present,-aside from the fact, of conrse, of the physieal motions having heen demonstrated? I hold not. Why should the secker after the ultimate nature of things be content to rest satisfied with these? He should logically ask, "What is the ultimate nature of vibrations?" 
and the answer to this would bring him back again to where he started, for he would be told that they were mind. Consciousness I conceive to be an ultimate, at least as far as physical processes are concerned, and hence the question as to its further ultimate nature must be an absurdity. This point, as well as the subject-matter of the last ehapter, has been dwelt upon at the expense of considerable repetition because of the importance of clearly recognizing what we mean by mind. When thus viewed, we get rid of the difficulty of conceiving how a mental and a physical process can be one and the same thing, and how a transition is effected between the physical change in the body and the subjective world of thought,- the passage between mind and body. This has been a difficulty which has been a stumbling-block in the way of all schools of philosophy, both spiritual and material. It matters not whether mind be a spirit or a manifestation of matter, the difficulty has becn found the same. This has already been pointed out. Even so advanced a writer as Dr. Carpenter, a writer of the physiologieal school, makes this admission. "Now in what way," he says, "the physical change thus excited in the sensorium is translited, so to speak, into that psychical change which we call seeing the object whose image was found upon our retina, we know nothing whatever." 1 Ferrier recognizes a similar puzzle, but just misses grasping what, I think, must eventually be reeognized as the true solution.

"But how it is that molecular changes in the brain-

1 Mental Physiology, p. 13. 
cells coincide with modifications of consciousness; how, for instance, the vibrations of light falling on the retina excite the modifications of consciousness termed a visual sensation is a problem which cannot be solved. We may succeed in determining the exact nature of the molecular changes which occur in the brain-cells when a sensation is experienced, but this will not bring us one whit nearer the ultimate nature of that which constitutes the sensation. The one is objective, the other subjective, and neither can be expressed in terms of the other. We cannot say that they are identical, or cven that the one passes into the other ;. but ouly as Laycock expresses it, that the two are correlated, or witl Bain, that the physical changes and the psychical modifications are the objective and subjective sides of a doublefaced unity." 1 Even such an extreme materialist as Büchner, who has been more soundly abused for his writings than any other matcrialist of the age by people, who either could not, or more generally would not, understand him, does not even at tempt to explain the connection between mind and matter. He contents himself with merely stating the existence of the connection. This connection becomes apparent now that the problem is found really to be not how molecular changes become transformed into consciousness, but how consciousness comes to be apprehended as physical changes. If the views that have been advocated above are accepted, this can readily be understood. It must be distinctly understood that it is not a question of translation or transformation at all, but of identification.

1 The Functions of the Brain, 1876. The italics are mine. 
Physical changes are not transformed into states of consciousness, nor are there "two processes" which occur "side by side" in the same person. There is only one process.

The common expression that " every state of consciousness is accompanied with a molecular change in the substance of the brain," which was for the sake of argument provisionally accepted in the preceding pages, must be regarded as unfounded and as leading to great confusion and misconception. A fecling is NoT accompanied by a molecular change in the sanc lrain; it is "the reality itself of that change." You may say, if you prefer, that a fecling in you may be ideally perceived by me as a molecular cliange, or that your feeling is ideally accompanied by my notion of molecular changes. But you cannot correctly say that a fecling is accompanied by a molecular change in the same organism, becanse this implies two distinct existences and leads to all the fallacies of materialism.

"It is not only inconceivable," writes Mr. Fiske, "how mind should have been produced from matter, but it is inconceivable that it shonld have been produced from matter, mnless matter possessed alrealy the attributes of mind in embryo, an alternative which it is difficult to invest with any real meaning." 1

Here we have a capital illustration of the ambignous use of the word matter; for when we elearly define to ourselves in which sense we employ the term the difficulty vamishes. Does Mr. Fiske here refer to subjective, actual, or phenomenal matter $?^{2}$ Not, cer-

1 North Am. Rev., Jan.-Feb., 1878.

${ }^{2}$ See page 33. 
tainly, to the first, for subjectice matter being a form of mind the statement loses all force, as it becomes equivialent to saying that mind could not have been produced from mind.

If by matter is meant phenomenal matter, the proposition is undoubtedly correct, for phenomenal matter, being only the product of an artifice, has no real existence. But with this admission it is difficult to sec much point to the statement, as I do not know as any one has ever imagined that phenomenal matter could produce nind. The supposition is mere nonsense, being equivalent to saying that something whieh does not exist can produce soncthing that does.

Finally, if by matter Mr. Fiske has in mind the notion of actual matter, then the proposition assumes an intelligible meaning, but at the same time can readily be shown to be untrue. By aetual matter we mean the unknown reality underlying phenomena, the thing-in-itself. It comprises all those unkmown forces or activities which constitute the ciscnce of the universe. If it is unknown, then we certainly are precluded from setting limitations to its possibilities. It may be inconecivable how mind should have been produced from this great mknown miverse, hecause such a conception would require an intimate knowledge of the nature of that which, by its very definition, is unknown. But, on the other hand, nothing forbids our conceiving that mind should be produced from such a universe; and the alternative, that in this ease matter must have possessed the attributes of mind in cmbryo, instead of being devoid of meaning, becomes invested with the deepest signification. It is not only possible, 
but in the highest degree probable, that those activities, the sum of which we call consciousness, are of a kindred nature to those activities which are the reality of phenomenal matter. Just as organic matter is marle up of the same physical atoms and molecules which make up inorganic matter, combined and recombined in varying proportions, so there is every reason to believe that states of conscionsness are the resultant of the combination and recombination of the elementary activities which are the realities of the physical atoms and molecules. The atom of hydrogen is the sime, whether it occur in a free state by itself or combined with two atoms of oxygen in the form of water, or with a great many other atoms of carbon, nitrogen, oxygen, and hydrogen in the living organic substance called protoplasm; and there is also every reason to believe that the "force," if we may enploy a term which derives its signification from our experience to denote that of which we have no experience, - there is every reason to believe, I say, that the force, which is the reality of the hydrogen atom, is the same whether that atom be in a free state, or in water, or in living protoplasm. Further, as the different combinations of the forces or Realities lying behind the atoms of inorganic substances exhibit themselves in the varying properties of such substances, so the various and more complieated combinations of the same forces in living protoplasm exthibit themselves in its properties or vital functions. By a still further combination of the activities molerlying the properties of the simplest form of living substance, a lump of protoplasm, and manifesting themselves in its vital functions, the primitive germs of conscionsness 
arise, and we obtain for the first time a glimpse of what these forces of the unknown universe may be. ${ }^{1}$ All higher states of consciousness are but combinations of the simpler forms.

1 This identification of the Reality of matter with the elements of consciousness wats clearly recognized by Clifford, and set forth by him with that brilhant felicity of expression and clearness of eonception which was pre-eminently his.

This Reality he calls mind-stuff. "That element," he says, "of which, as we have seen, even the simplest feeling is a eomplex, I shall eall mind-stuff. A moving moleeule of inorganie matter does not possess mind or consciousness; but it possesses a small piece of mind-stuff. When molecules are so combined together as to form a film on the under side of a jelly-tish, the elements of mind-stuff which go along with them are so combined as to form the faint beginnings of sentience." Again; "The universe, then, consists entirely of mind-stuff. Some of this is woven into the complex form of human minds containing imperfect representations of the mind-stutf outside of them, and of themselves, as a mirror reflects its own inage in another mirror ad infinitum. Such an imperfect representation is called a material universe. It is a picture in a man's mind of the real universe of mind-stuff. The two ehief points of this doctrine may be thus summed up:

"Matter is a mental picture in which mind-stutf is the thing represented.

"Reason, intelligence, volition are properties of a eomplex which is made up of elements themselves not rational not intelligent, not conscions." Things-in-themselves.

Mr. Spencer secms also to have eome round to this idea, and clarly expressed it in a late article, which has given rise to eonsiderable discussion. "Consequently," he says, "the final outcome of that speeulation commeneed by the primitive mm is that the power manifested throughont the miverse distinguished as material, is the sume power which in ourselves wells up under the form of conscionsness." - Religion-a Retrospect and Prospect. Nineteenth Century, Jan., 1884. 
Thus it becomes intelligible how matter, meaning thereby actual matter, may possess the "attributes of mind in embryo." But such use of langnage is metaphorical, and is justifiable only on the recognition of the fact that it is metaphor we are using.

But after admitting that conscionsness is the reality of physical processes, the question may be asked; Is there still something more underlying consciousness, some sulstance of which conscionsness may be (as Mr. Spencer holds) a mode or manifestation? Mr. Spenrer's view, I take it, is that conscionsness is not the reality of physical processes, but an aspect or manifestation of this reality. This reality he then calls the substance of mind, and argues that it is the mnknown.

I confess that after a carcful and patient study of Mr. Spencer's arguments I am unable to admit their force.

Grant the existence of this substance of mind, and it necessarily follows, as he has so ably argued, that we can know nothing of it. But what is this hypothetical "Snbstance of mind," and what are its relations, on the one hand, to the cerebral vibrations which " mnderlie thouglit," and, on the other, to Thought itself? The minute we ask these questions and seek for answers that will enable us to form a clear conception of what sort of part this substance is supposed to play, its mystic nature at once hecomes apparent. For any hypothesis to be comprehensive and satisfactory it is essential that we should be able to form a definite and clear picture in our minds of the conditions which we suppose to be present, but I cloubt very much whether any one can form such a pieture from $\mathrm{Mr}$. Spencer's 
exposition of the subject, whatever Mr. Spencer's own condition of mind may be. Nay, more, I do not see how different patssages in his writings can he reconciled one with another.

In the first place, what evidence can be adduced in favor of this Substance. "Let us yield," he says, "to the necessity of regarding impressions and jeleas as forms or modes of a continually existing something. Failing in every effort to break the series of impressions and ideas in two, we are prevented from thinking of them as separate existences. While each particular impression or idea can be absent, that which holds impression and ideas together is never absent, and its unceasing presence necessitates, or incleed constitutes, the notion of continuous existence or reality."

I am unable to see in this more than a subtle playing with thonght, if not with words. Arlmitting that while conscionsness is present we cammot have an idea or impression isolated from every other idlea or impression, which is, I presume, what is meant by failure to break the series in two, I fail to see this logical necessity which compels us to thus look upon ideas as "modes of a continually existing something" and which prevents us from regarding them an separate existences; or at any rate, whether we do the latter or not depends npon what is meant ly existence, a question which, if entered into here, would prolong too firr this discussion already grown to great lengtli. The argument also contains a manifest petitio principii. "That which holds impressions and ideas together is never alssent," it is salid. 'This an only he asserted on the assumption that there is something more than 
and in addition to conscionsness, which holds every state of conseiousness together. But the only proof of this is the assertion, or a possible inference from our failure "to break the series of ideas and impressions in two;" an inference which ignores all other possible explanations. The existence of this substance of mind is first assumed, and then said never to be absent. It would not be irrelevant to ask what becomes of this substance during sleep and similar states of unconsciouness, and how it is known that here it is not absent. When we analyze our thoughts, we find that we know only suceessive and coexisting states of eonseiousness,--nothing more,-and though we may infer there is something more underlying then and holding them together, such a conchision would be an inference which may or may not he true, and, as Mr. Spencer argues, we can know nothing about its nature whatsoever. It seems somewhat strange, then, that $\mathrm{M} \mathrm{r}$. Spencer should assume that, "by the definition, it [the substance of mind] is that which undergoes the modification producing a state of mind." For, as we ean know nothing about it, it would scem evident that we camnot know whether or not it is capable of " nndergoing a modification." This seems a curions assumption regarding the qualities of a thing which it is one's endeavor to show is absolutely mknowable, which Mr. Spencer proceeds to do.

But admitting the existence of this substance of mind, what is it, and what are its relations to states of conscionsness and to the physical vibuations of the brain? At first sight it would seem-and this interpretation is most in hamony with other passages in 
Mr. Speneer's writings-that the substance of mind is identified with the Unknown Reality lying behiunl the phenomena of phesical motion; so that this enreat Unknown "Force" is eaprable of being presented to our conscionsuess under two forma; namely, when viewed throngh the senses as physieal vilurations, when otherwise viewed (hoov?) an states of conseionsnesi; but in either ease the Reality always remains unkmown. This seems to be elearly enongh meant in the passigne, "For what is objectively a change in a superior nervecentre is suljectively a fecling, ant the duration under the one aspret measures the duration of it muder the other." I And again in the passage, "When with these conclusions that matter and motion, an we think them, are but symbols of unknowable forms of existence, we join the conchision lately reached that mind also is nnknowable, and that the simplest form under which we can think of its substance is but a symbol of something that can never be rendered into thought; we see that the whole question is at least nothing more than the question whether these symbols should be expressed in terms of those, or those in terms of these, a question seareely worth deeiding, since either answer leaves us as completely outside the reality as we were at first." 2 This view of the case is essentially the same as that which was held by Lewes.

The oljections to regarding states of eonsciousness as a mode of apprehending or as symbols of an Unknown Substance will be presently given. I may briefly say here that any such conception makes the relation be-

1 Loc. cit.

2 Op. cit, P. 159.

D 
tween the states of consciousness we call cerebral motions (subjective matter) and the Unknown Reality (actual matter) similar to the relation between that consciousness which is said to be correlated with those motions and this same Unknown Reality, which is impossible.

But, on the other hand, if this be the intent of $\mathrm{Mr}$. Spencer's position, why should consciousness be regarded as a mode or manifestation of the substance of mind? As has been said, this substance being something far beyoud the possibility of our knowledge, we cannot even say it is capable of having modes or manifestation.

The radical distinction between Mr. Spencer's position and mine is this: He supposes an unknown Reality, which, when apprebended through the senses, is recognized as physical motions, but which, after having undergone certain modifications, becomes known as mind. (How ?)

The view here maintained is that every state of consciousness is not a "mode or manifestation" of an unknown Reality, but is the Reality itself, which is therefore known, and which becomes recognized as a physical motion of some kind when apprehended by a second person through the senses.

Mr. Spencer's views have led him to the conclusion that "Though mind and nervous action are the subjective and objective faces of the same thing, we remain utterly incapable of seeing and even imagining how the two are related." On the other hand, the views here maintained show elearly and satisfactorily how the two are related.

Mr. Spencer deseribes consciousness indifferently as "morles or manifestations," "symbols," and "aspects" 
of an underlying sulsstance. But no such language can be used to describe the conditions we have endeavored to prove.

In only one sense cau there be said to be an Unknown Substance of Mind, and this we can arrive at only by objective inquiry. The molecular motions which correspond to any state of consciousness take place in a very highly organized substance, the protoplasm of the brain-cells. Now this substance is of a very complex composition, being made up of a very great number of atoms of carbon, hydrogen, nitrogen, and oxygen. But to each atom there is a corresponding unknown "force," which is the Reality of it, while the Reality of a molecule of protoplasm may be regarded as the result of the combination of Realities of the atoms. Going further, whether we adopt the vortex theory of Thompson or not, as there is reason to believe the atoms of different chemical elements are compounds of some simpler substance, which for the sake of illustration we may call hydrogen, so the Realities of these different chemical atoms will be the combination in varying proportions of the centres of force lying behind the hydrogen atom. The Reality, then, which is the unknown "force" lying behind and corresponding to that group of sensations we call a molecule of cerebral protoplasm, will be a compound of the Realities of its ingredient atoms, which in turn are a compound of the Reality of the primitive (hydrogen ?) atom.

Now as the interaction of the Realities of the protoplasmic molecules constitutes consciousness, we may imagine different states or kinds of consciousness to 
correspond to the interaction of varying groups of molecules of the same or different chemical composition, these molecules being contained in a varying number of cells of the brain.

The Reality, then, of the molecule of protoplasm in contradistinction to the Reality of the interaction of the molecules might in this sense be regarded as the snbstance of mind, though the same process of reasoning would compel us, perhaps, not to rest here, but to continue our analysis until we had arrived at the reality or force underlying the group of sensations called the atom of hydrogen, or whatever the primitive substance may be. This would then be the Substanee of Mind.

This brings us to another matter which has already been touched upon, but on which it was promised that something more would be said. I refer to the matter of "Aspects." IVe have seen how physical processes and consciousness have been spoken of by some as dual properties of matter. So, in the same way, conscionsness is often referred to, so far as the reality is concerned, as facts of the same order as physical processes; that is, as "phenomena" and "symbols of the unknown." Thus, to requote Mr. Spencer: "When with these conclusions, that matter and motion, as we think them, are but symbols of unknowable forms of existence, we join the conclusion lately reached, that mind also is mknowable, and that the simplest form under which we can think of its substance is but a symbol of something that can never be renlered into thought, we see that the whole question is at least nothing more than the question whether these symbols should be expressed in terms of those, or those in terms of these,-a question 
scarcely worth deciding, since either answer leaves us as completely outside of the reality as we were at first." 1

Now it may very properly be questioned whether a state of mind, as a feeling, can be conceived of as a symbol of its own substance. We can say an idea of anything external to us, as of a tree, is only a symbol of the actual something which exists there; for the idea of a tree is only the effect which the actual object produces on the mind, just as the impression in wax of a seal is a representation or symbol of the seal; or better, as the printed word is a symbol of the idea it represents, but, as a printed form, has nothing in common with that idea.

But in this case there are required and present two things, - one, the something to be symbolized, the treein-itself, and the other, the something in which the symbol is to be formed, the mind, and one is distinct from the other. But for a state of mind to be a symbol of its own substance, it is requisite that this particular state of mind should have an existence separate from that underlying substance, or, in other words, separate from itself. Otherwise the state of mind could not be acted upon by the substance. But if it is separate, it is a distinct entity, and then this underlying something cannot be the substance of mind. In brief, to quote Mr. Spencer himself in another connection, "A thing cannot at the same instant be both subject and object of thought, and yet the substance of mind must be this before it" can be both the symbol and the thing symbolized.

Whatever view be taken regarding the existence and 
nature of a something underlying consciousness, it is quite evident that the lattcr cannot be regarded as facts of the same order as its "accompanying" physical changes, as is done when both are regarded as symbols of something else.

This same looseness of thought and language has led to physical and mental processes being regarded as different "aspects" of the same thing.

Even so acute a thinker as $\mathrm{Mr}$. Lewes has described mind and physical changes as different "aspects of one and the same process." This cannot be the correct conception, for it also makes matter and feeling facts of the same order. If mind and matter are to be regarded as "aspects," it must be that either they are aspects of each other or of a third thing, as of Speneer's substance of mind.

In the former case matter might be regarded as an aspect of mind, but mind cannot be imagined as an aspect of matter, as appears to be meant when Lewes says, "a mental process is only another aspect of a physical process." Now a physical process may cer-• tainly be looked upon as an aspect of a mental process, becanse it is the effect of the mental process on another organism, but the mental process being the actuality of the physical process,- - the physical process in itself,there is nothing for it to be an effect or aspect of. What las been said in regard to the conception of mind as a symbol is equally applicable here.

Under the second alternative, that they are different aspects of an underlying substance, physical processes may also be aspects, but mental processes not. For,

1 Physical Basis of Mind, p. 386. 
in order that the latter may be an aspect of this substance, there must be another substance or mind on which the underlying substance can work to produce the effect or aspect called consciousness. But where is there such another substance? We each of us have only one mind apiece.

This may be expressed in another way. To speak of anything as an aspect of sometling elso implies something perceived and something perceiving, and the effect of the former upon the latter is the aspect of the former, the thing perceived. Now for consciousness to be an aspect of the substance of mind there is required, in addition to this substance, another thing or mind to perceive it, and conscionsness must be the effect of the former upon the latter. But where is this second mind? There is none. Such an assumption would require a second entity, as a spirit. Therefore, if matter is an aspect, or the reaction of an organism to something else, conscionsness camnot be aspect. The two can never be spoken of as facts of the same cla-s. Besides, as was said in Chapter I., if these two classes of facts conld be regarded as simply the suljective and objective aspects of one and the same thing, it would fall far short of offering us an adequate explanation, and would involve us in many difficulties such as lave been pointed ont.

Exception may be taken to that meaning of the term "aspeet" which I liave employed. But if aspeet is not to be taken in its ordinary and exact sense, then it must mean very little or anything that one may choose, and is still more objectionable as an interpretation of the question. 
The same objection holds to the expression that matter and mind are only "different modes of apprehending the same thing." Conscionsness cannot be a mode of apprehending something else, because this also implies the existence of something else that apprehends. What is it?

Again, if by the term matter be meant the conscious states by which things-in-themselves are known to us, then matter and mind are plainly not two different aspects of the same fact. On the contrary, they are clearly different psychical facts. The sensation of mental tremors is one fact, the conscious state which is the reality of those tremors is another fact. Each is a subjective fict occurring in separate organisms. The conscious state called a sensation of color takes place in organism A, for example, and the conscious state called neural tremors in organism $B$, which is observing $A$. But the conscious state in $A$ is the cause of the conscious state in B, which latter cau, in this sense only, bc said to be an aspect of the state of $A$, but not vice versa.

If by matter be meant not phenomena, but the thingin-itself, then still less can matter and mind be regarded as different aspects of the same fact. For by cerebral tremors we now mean the reality of these tremors, and, as I have endeavored to demonstrate, this reality and consciousness are one and the same fact. This will become intelligible if the reader will refer to what was said regarding the meaning of the term matter in Chapter II.

On pursuing this mode of inquiry further, certain important results follow, which it will be necessary for us to consider. 
Let us suppose a complicated apparatus, as of microscopes, by which B observes what takes place in A's brain when he has a sensation of color, for example; and $\mathrm{C}$ observes what occurs in B's brain at the same instant. Then it would happen that at the moment when $A$ has the sensation of redness, $B$ luas the sensation of cerebral tremors, and also $\mathrm{C}$ has a sensation of tremors. This may be graphically represented as follows :

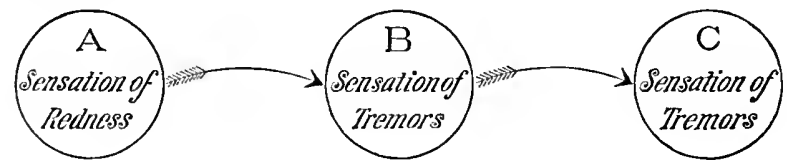

We have then the following as a result of these conditions :

In organism A : Sensation of color; an actuality and the reality of,

In organism B: Cerebral tremors; a conscious state, and as such also a reality, but also commonly known as phenomena or matter when projected outside of the organism and given objective existence in A. It is the form in which color in $\mathrm{A}$ is symbolized in $\mathrm{B}$.

In organism C: Cerebral tremors; a conscious state, and as such an actuality, and the form in which the conscions state in $\mathrm{B}$ is syubolizer in C.

Cerebral tremors, then, are a conscious state, which may be a form of apprehending in a second organism either, 
1st. An unlike conscious state,-sound, color, thought, ete.

2d. A similar conscious state or cerebral tremor.

In this instance of $\mathrm{C}$, then, we are brought to what seems at first the surprising fact, that that conscious state called cerebral tremors, which is the cognition of the thing-in-itself, and known as phenomena, and the thingin-itself, also cerebral tremors in B, are similar though separate facts. And under the conditions just mentioned it might almost be sairl that neural tremors exist outside of us as such; or in other words, that such phenomena exist practically as we see them. I say practically, for although the conscious state, neural motions, possessed by one organism, may be perceived by another also as neural motions in the brain of the former, still it does not follow that these first motions would be perceived as the same kind of motion. They would be perceived as motion of some kind, but not necessarily as the same kind. For instance, taking the same illustration used above, A's sensation of color might be perceived by $B$ as undulatory motion; the conscions state of undulatory motion in B might be perceived as circular motion by $\mathrm{C}$; which again might be represented in D's consciousness by spiral motion, and so on. I do not mean to say that these particular motions do actually exist. That would depend upon physical conditions not yet understood. All I mean is that some kind of motion or physical change may under some conditions be the mode of apprehending a motion which may or may not be the same in kind; and we perceive the thing-in-itself as it really exists. 


\section{CHA P TER V.}

\section{THE CORRELATION OF FORCES.}

WE have now arrived at a position to consider another element in this problem, and one for which it is essential to find a satisfactory explanation. I refer to the law of the Correlation of Forces. If states of mind are simply states of matter, it is insisted they must be brought into harmony with all those general laws which govern the phenomena of matter. The difficulty of finding an application of this law to mental conditions has been generally recognized, and this difficnlty has been taken advantage of by those styling themselves "antimaterialists," and urged with considerable force as an objection. Unless this objection ean be met, materialism must admit a vulnerable point. For those who are unfamiliar with physical science, it will be necessary for a thorough eomprehension of the argument to state with some fulness the meaning and application of the phrase "correlation of forces." I cannot do this better than in the words of Mr. Fiske, who at the same time forcibly states the objections we are obliged to meet: "Let us now apply these principles to the case of an organism, such as the luman body. All of the 'foree'-i.e., capacity of motion-present at any moment in the human body is derived from the food that we eat and the air that we breathe. As food is 
turned into oxygenated blood and asimilated with the various tissues of the body, which thenselves represent previously assimilated food, the molecular movements of the food material become variously combined into molecular movements in tissue,-in muscular tissue, in adipose, in cellular, and in nerve tissue, and so on. Every undulation that takes place among the molecules of a nerve represents some simpler form of molecular motion contained in food that has been assimilated; and for every given quantity of the former kind of motion that appears, an equivalent quantity of the latter lind disappears in producing it. And so we may go on, keeping the aceount strictly balanced, until we reach the peculiar discharge of unclulatory motion between cerebral ganglia that uniformly accompanies a feeling or state of conscionsness. What now ocenrs? Along with this peculiar undulatory motion there occurs a fecling,-the primary element of a thought or of an cmotion. But does the motion produce ${ }^{1}$ the feeling in the same sense that heat produces light? Does a given quantity of motion disappear, to be replaced by an equicalent quantity of fceling? By no means. The nerve-motion in disappearing is simply distributed into other nerve-motions in varions parts of the body, and then other nerve-motions, in their turn, become variously metamorphosed into motions of contraction in muscles, motions of secretion in grands, motions of assimilation in tissues generally, or into yet other nerve-motions. Nowhere is there such a thing as the metamorphosis of motion into feeling, or of feeling into motion. Of

1 Italics in the original, but the other italics are mine. 
course I do not mean that the eircuit, as thus described, has ever been experimentally traced, or that it can be experimentally traced. What I mean is, that if the law of the 'correlation of forces' is to be applied at all to the physical proeesses which go on within the living organism, we are of necessity bound to render our whole aceount into terms of motion that can be quantitatively measured. Once admit into the circuit some element - such as feeling-that does not allow of quantitative measurement, and the correlation can no longer be establisheel; we are landed at once into absurdity and contradiction. So fin as the correlation of forees has anything to do with it, the entire circle of transmutation, from the lowest physico-chemical motion all the way up to the highest nerve-motion and all the way down again to the lowest physico-chemical motion, must be described in physical terms, and no account whatever cam be taken of any such thing as feeling or conscionsness." 1

The realer will immediately perceive how the idea of feeling, being something more than and in addition to those activities called motion, pervades the whole passage. This is especially evident in those passigres indieated by italies. "Along with this peculiar undulatory motion there occurs a feeling,- - the primary element of a thought or of an emotion." "Doess a given quantity of motion disappear, to be replaced by an equiralent quantity of feeling?" The idea of feeling being something plus physical activities could hamlly be more plainly stated. With this falte conception as a

1 North Am. Rev., loc. eit. 
starting-point, the conclusion affirming the inapplicability of the correlation of forces naturally follows.

After what has been said in the preceding chapters, the reader will, without difficulty, recognize the fallacy of this conception of double processes, no matter - whether the second property be looked upon as spiritual or physical. It leads, as was averred on page 25, and as Mr. Fiske has well shown, to the destruction of the universality of this law of correlation. But materialism must not be blamed for the shortcomings of its interpreters or the misconceptions of its opponents. If it can be shown that materialism cannot be reconciled with the law of the correlation of forces, materialism must fall. But this is far from being the case. When Materialism is properly understood no such difficulty is met with. Before consigning any doctrine to oblivion, it would be becoming in its opponents to examine once more their own interpretation of that doctrine, and see if the fault does not lie with themselves. Having begun by misunderstanding the doctrine of materialism, they naturally end by finding fault with errors which are of their own making. They should be more careful not to mistake their own blunders for those of nature.

But is this statement just quoted respecting the inapplicability of the law of the Correlation of Forces to Mind true of that interpretation of materialism maintained in these pages? Let us see. "Along with this peculiar form of undulatory motion there occurs a feeling,-the primary element of a thought or of an emotion." This is not correct. There are not two things which oceur simultaneously in one organism. 
There occurs solely the Feeling, and the undulatory motion is only the subjective expression of another person's perception of this feeling. Therefore it obviously cannot be said that the motion produces the feeling, for the two are one.

"Does a given quantity of motion disappear, to be replaced by an equivalent quantity of feeling?" If the term "motion" is here employed to represent that cerebral motion which is commonly though incorrectly said to accompany a feeling, the answer must be "No," for the reason just given. But if it is used to designate those motions which occur in the sensory nerves, and if we bear in mind what we mean by such motion, an affirmative answer may be given. Let me explain by an illustration what I inean. Let us suppose that we have been pricked in the arm by a pin. As a result we have a sensation of pain, which in turn causes us to withdraw the arm. We have here what is called a nervous circuit. In the sensory nerve going to the brain there is exeited some " nerve-motion," which in turn travels to the cerebral centres, where this motion is exchanged for cerebral motion in the cells of the brain. From henee it issues again along the motor nerves as nerve-motion, until it finally reaches the muscles to become muscular motion. Here is a dynamic circuit. But where is fecling? Has it entered into it? Not at all; because we have been employing physieal terms. We cannot change nue term of the eqnition withont changing all the others to correspond, any more than we can add quarts and pomds together, but each must be reduced to the same standirrd of measurement. If we wish to bring feeling into the circuit, we 
must employ a corresponding set of symbols. It will then be expressed as follows: The molecular disturbances in the nerves, designated by nerve-motion, must be represented by the term "unknown $x$." The diffienlty is that the ordinary use of language carries with it pitfalls and dangers, which can only be avoided by keeping constantly before the mind the reality which is represented by the word. When we talk of nerve-motions, the most wary are liable to be misled; and even the more general term "physical disturbance or activity" contains an ilea of something that we see or feel, and the unknown conditions for which it stands are lost sight of. In this way terms of different measurement are introduced into the equation, and the real question becomes lost in one of words.

It is better, when dealing with ultimates, as we are when we talk of feeling, to employ such indefinite terms as $x$ or $y$, which have no preconceived notions attached to them, instead of spcaking of motions and undulations which are not ultimates. Letting $x$, then, stand for the unknown changes in the sensory nerves, and $y$ for those in the motor, we can say that unknown $x$ becomes transformed into an equivalent amount of conscionsness; that consciousness becomes again transformed into an equivalent amount of unknown $y$, and with each metamorphosis a certain amount of the one factor disappears, to be replaced by an equivalent amount of the suceeding factor. We have here, then, a circuit of ultimates corresponding to and identical with the dynamic nervous circuit, and the principle of "correlation of forces" becomes applicable to the facts of consciousness. 
But is it necessary that we should use these indefinite expressions in order that this law of correlation may be applied to the subjective world? I think not, if, as I have said so many times before, we are careful not to mistake the symbol for the reality symbolized. We can say that in traversing the nervous circuit the nervemotion in the sensory nerves becomes transformed into an equivalent amount of cerebral motion, or consciousness, which in turn disappears to become nerve-motion again. But now we must remember that "cerebral motion" and consciousness are one and the same thing. Only the former is a symbol of the latter. Not the gold and silver side of an iron shield, but a gold shield, one side of which has been silvered. If we wish to measure these motions by mechanical apparatus, of course it must be the cerebral motions, not consciousness, which are to be measured; for mechanical methods can only be applied to the conditions to meet which they were designed. I have discussed the application of this law of the correlation of forces in a very general way, referring only to the principles underlying it. It would take us too far out of our way to consider all the complex conditions entering into the equation of its application,-what amount of "nerve-motion," for example, in a sensory nerve passes into other nervemotions in outgoing nerves withont the intervention of consciousness; how much becomes transformed into consciousness; how much finds its equivalent in disturbances in the sympathetic system and in nutritive tissue change; and, finally, how much consciousness is balanced by the previons molecular action of the food storing up, so to speak, mind-force in the cells of 
the brain, ready to be discharged like a mine of gunpowder on lighting the fuse. These questions physiology is not sufficiently developed to answer at present.

If the distinctions dwelt upon above are borne in mind, the difficulty ceases to be one of mere words, and one of the strongest objections to the materialistic doctrine of mind is avoided. We see how movement may be the cause of thought, and thought of movement. The assertion of Lange, ${ }^{1}$ that "were it possible for a single cerebral atom to be moved by 'thought' so much as the millionth of a millimetre out of the path due to it by the laws of mechanics, the whole 'formula of the universe' would become inapplicable and senseless," can only be maintained on the assumption that mind is something more than matter, a spiritual entity.

Thought can move an atom, for it can move the unknown ultimate which is the basis of that group of phenomena we call an atom. But to insist "Ipon this precision of statement is a mere quibble over words, though the superficial criticisms of Lange ${ }^{2}$ may sometimes render it necessary.

1 History of Materialism.

${ }^{2}$ Ibid., vol. iii. p. 9. 


\section{PART II.}

\section{HUMAN A UTOMATISM.}

"Wherefore, as men owe all their true ratiocination in the right understanding of speech, so also they owe their errors to the misunderstanding of the same; and as all the ornaments of philosophy proceed only from men, so from man also is derived the ugly absurdity of false opinions. For speech has something in it like to a spider's web (as it was said of old of Solon's laws), for by contexture of words tender and delicate wits are ensnared and stopped, but strong wits break easily through them."

Hов в Es. 



\section{CHA P'TER I.}

THE PEFLEX CHARACTER OF IDEAS.

Havisg thus far been occupied with the consideration of the nature of mind, we are now prepared to enter upon the second part of our subject, or Human Automatism. But as what will follow consists only of deductions from the principles laid down in the preceding chapters, it was absolutely essential that we should first see that these principles were well established and elearly understood. It is to be hoped that this has been done, and that that interpretation of materialism has been given which is both consistent with the facts and affords a complete explanation of the mystery of conscionsness. It is hecause proper pains have not always been taken to establish the correctness of the first principles, that such extraordinary and indefensible deductions have sometimes been drawn.

We have seen how conseionsness is nothing more than the reality of those physical processes we call undulations, and that the latter are only the means by which eonscionsuess becomes known to ws when apprehended by a second porson through the senses,-in fact, the symbols of conscionsness.

But this doctrine involves logieal consequences from which there an be no escape, and which we cannot avoid considering. 
As physical processes are symbols and equivalents of conscionsness, we can, through the physical method, let them stand for mental processes, study them as such equivalents, and investigate the conditions under which they arise. Afterwards we can translate the results into terms of consciousness.

Now that matter, of which consciousness is the reality, must be subject to the laws which govern matter. One of these laws is the law of inertia. According to this, matter cannot of itself change its own state. Matter at rest must forever remain at rest, unless something outside of itself disturbs it and puts it in motion. Matter in motion must forever persist in motion till something outside of it checks it. Matter exhibited under one property must forever be exhibited under that property, unless some external force causes it to be exhibited under another. Whatever be the state of matter at a given moment, it must always remain in that state till outside agencies effect a change. This is a universal law; it has no exception. To this law, then, the " matter of the mind" must be subject. Let us apply it and see what it means. It means this: that no change of any kind, chemical or physical, can occur in the protoplasm of the brain without the interference of outside agencies; that no vibration or pulsation can occur among the protoplasmic molecules of any cell unless some cause extemal to that cell acts upon them; that for the imdulations of the molecules-of which consciousuess is the reality-to oecur, some external force is requisite to start them into activity; in other words, for consciousness to be present it is necessary that each cell should be stimulated by something exter- 
nal to that cell. ${ }^{1}$ The activity of the molecules of no cell can appear spontaneously, and hence neither can the reality of that activity, or conscionsuess. Consciousness, then, is passive, not active; it is conditioned existence, not unconditioned; it is a link in a series of events.

Such is the inevitable result to which our reasoning leads us. If conscionsness depends on matter being disturbed, it must be passive. This is a logical consequence of our premises, from which there is no escape. But if our thoughts are passive,-if they are merely the molecular disturbances in themselves and cannot arise spontaneously, -it must be that the stimulus required for their prorluction cannot be applied in any indefinite manner at haphazard, but only through the anatomical mechanism of the brain,- - only through the nerve-conductors developed for the purpose. The channels by which stimuli from withont reach the cells of the brain are the centripetal nerves; and any succession of ideas can only occur by reason of the neural "cur-

1 Objection may be made to this on the ground that, conseiousness being the reality, the laws which govern phenomena cannot be applied to it. But I have already shown (Chapter Y.) that by a change of all the terms in the series the law of correlation of forces may be extended to mental processes. Furthermore, the physieal process being the equivalent and symbol of the mental process, we ean substitute the one for the other; and having worked out the problem, retranslate the results back again inte the original terms. It is not possible to conceive of the nenral vibrations being absent or present without its reality, conscionsness, being similarly absent or present; and anything which, from a plysical point of virw, causes the occurrence of the vibrations must, from a psychological point of view, have an equivalent result in conscionsness. 
rents," wherever originated, being refleeted from one cell to another along the anatomieal connections which join the cells; and any objective expression of an irfea can only take place by reason of the current passing again from the brain to the organs of expression, which are the muscles. In other words, under normal conditions, every muscular action, every idea, sensation, or emotion requires for its production some stimulus originating outside of its own nervous centre,-that is, it is reflex. ${ }^{1}$

I think it is possible to show, by reference to the faets of physiology and pathology, that from the simplest muscular act, such as the winking of the eyelicl, to the most complex muscular actions and trains of thought, there is never a difference in kind, only one of degree; that we can pass from one to the other by a series of gradations, step by step, and find them all of the same nature, reflex in charaeter.

There is one oljection to this conclusion respeeting the reflex character of ideas which, at first sight, appears plausible, but yet, whatever validity it may have, does essentially affect the prineiple of the hypothesis. It may be urgerl (and, from a philosophical point of view, correctly) that, even if the physical process in the brain be a reflex one, this term, which derives its meaniug from physical conditions, camnot be applied to de-

1 There is one probable exception to this, and that is when ideas under abnormal eonditions are caused by direct irritation of the blood, as in delirium, or by foreign substanees, as oprium. But in this case thr ideas ar" still pasive, and it is probable that only some of these ideas are due to direct irritation and the remainder are reflected, as shown by the association of allied ideas. 
note the character of psychical facts. When we say, for instance, that certain nervous processes are reflex, we mean that the neural current passes along certain ingoing nerves to certain groups of neural eells in the brain; that then the current, after having started eertain reactions in the molecules of the cells, is reflected from ecll to cell, a similar effect being produced in each; and, finally, that the current is reflected outwards along eertain outgoing paths to the muscles, to end in action of some kind. We can even form a picture in the mind of all this, and perhaps graphically represent it on paper. But no such picture ean be drawn to illustrate the relation of the psyehical facts, the ideas, which are the reality and correspond to this process. We can see that one idea is invariably associated with another idea ; that one follows another according to certain laws of thought, which we can formulate from onc former experience. But this association is nothing like the picture we formed of the reftex physical process. All this is undoubtedly true, but nevertheless it camnot be regarded as a fatal oljection to the hypothesis advanced, nor as irreconeilable with all the facts. Ideats are the reality of the physical process, and though they camnot, by a strict use of terms, be said to be reflex, still the relations between them are of a nature that correspond to the reflex physical process; so that ideas in some way, which possibly camnot be translited into thought, are bound together in a fashion which has its comuterpart in the reflected neural current and cellular commotions. The reality of the cellular commotions are ideas, and the reflected physical process is the manner in which these realities are recognized by us when 
apprehended through the senses. This use of physical terms to describe subjective conditions need not be fallacious or regarded as unphilosophical if we only have in mind the conditions for which the terms stand. ${ }^{1}$

${ }^{1}$ See also note to page 96 . 


\section{CH A P'TER I I.}

CONSCIOUSNESS AS AN AGENT IN THE DETERMINATION OF BODILY ACTION.

THE outcome of our inquiry thus far has resulted in a theory which both explains the "relationship of the mind to the body," and also the mechanism by which mental action takes place. This theory at once satisfies all the conditions of the case, and explains the mysteries which have so long lung about the problem. We have seen how the very question, "How is the mind related to matter?" involves erroneons assumptions regarding the nature of each, which mike the question itself an absurd one. In the reflex theory of ideas we find a mechanism by which the human mind carries on all its manifold operations, from the simplest mental aet, like the sudden start of the body at the sound of a cannon, to the most complex train of thought. In passing from the more simple to the more complex the paths of thought become more circuitous and more complieated, but the process does not change. The difference is in degree, not in kind. On the physical side the current is reflected from cell to cell till it finally ends in the ontgoing current which terminates in museular aetion; and on the mental side, each thought, which is the reality of the physical process, is attached, so to speak, in some unknown way to each succeding thonght in such a manner that one necessa- 
rily ensues upon the other, according to certain psychological laws. Every idea calls up the particular idea which is associated with it in the same chain of ideas, to end finally, also, in muscular action; though, as each chain is linked with hundreds of other chains which cross its paths, fresh stimuli may switch the current of ideas along these connecting chains into fresh circuits.

To this reflex view there are logical consequences from which I see no escape. From the theory that a mental process is the reality of the reflex physiological process to the doctrine of automatism is a step which we are compelled by the force of logical necessity to take, or rather, the two doctrines are essentially the same. For any doctrine which removes our thoughts from the control of a hypothetical agent which is independent of external influences, and confines them to certain channels in which they are propelled, directly or indirectly, by stimuli (external or internal) is practically automatism. Under the reflex view, spontaneity, in the sense that any idea or state of mind can arise except as the resultant of some other idea by which it is conditioned, is impossible. Reflex is, consequently, equivalent to automatic.

On the other hand, the automatism which we are compelled to adopt is modified in a most important particular by the discovery of the relation which mind bears to matter. By this modification the principal objection to automatism is removed. As we have already seen (Chapter I.), and as we shall presently see more fully, some automatists, from a failure to take into account the testimony of direct consciousness, have given expression to a theory according to which all 
our actions are accomplished by the physiological mechanism of the brain, without being influenced in any way by volition or feeling. These latter are limited to the part of indicators to tell how the physical machinery beneath is working, nothing more. Any such notion of automatism can only arise from an illdigested consideration of the fucts and a total misconception of the problem in question. Now, on the contrary, the form of automatism which is the outcome of the reflex theory we have formed takes into account the testimony offered directly by conscionsness, and recognizes fully the part played by volition in acting on the bodily mechanism and determining our actions. The great merit of the doctrine of the nature of mind which has been adopted in these pages is that it harmonizes our subjective and objective knowledge, and not only allows to consciousness the power of acting on the molecules of matter, but renders intelligible how it acts. Conscionsness is as much an agent in determining physical action as molecular motion is,nay, it is more.

That I do this or that because I feel so and so is a psychological fact beyond dispute. No amount of reasoning can argue me ont of the belicf that I drink this water beeause $I$ am thirsty. But this is only stating the problem in other terms,-in psychological instead of physiological terms,-and does not in any way contradict our hypothesis. We can indifferently say that any action is dependent upon the organic comection of the nervous elements, or say it is dependent upou our feelings. It nust be remembered that a subjective process and a neural disturbance are, at bottom, one 
and the same thing, and either may be said to be the cause of the ensuing action, if we bear in mind the terms in which the fact is expressed. But in one sense it is more correct to speak in terms of feeling and thought than in those of matter. Ideas, sensations, etc., are the ultimates, the final terms to which phenomena can be reduced. They are actualities, and well known to us, while physical undulations, ete., are not, being merely phenomena. Hence it is more correct to use psychological terms, in speaking of mental "phenomena," than physical terms.

It was shown in a preceding chapter how, from a misunderstanding of the real relation between mind and physical changes,-how, from the conception of consciousness being something in addition to neural undulations, - the conclusion naturally follows that, as muscular action was only in direct connection with the physical changes of the brain, consciousness, which was something more and outside the former, could have nothing to do with the production of our actions, and must be merely a collateral product. This conclusion followed logically from the premises, but was also drawn unwarrantably from certain experiments on animals. The bearing of these experiments upon the point at issue will be discussed presently. We are now considering this conclusion as a logical deduction from the premises referred to. The adversaries of the modern doctrine, as well as its disciples, were not slow to point out that it is a psychological fact that our feelings are the cause of our actions,--that when we rub a spot where we have been bitten by a mosquito, we do it because we feel uncomfortably at that spot. 'This is a 
fact which every one can verify as often as he pleares. This being so, the logical inference which should be drawn is that there is some fallacy in the premises. But the opponents went further, and inferred that if our feelings are the cause of our actions, then we cannot be automata. This is an unjustifiable inference because there is no evidence that one excludes the other. It las been thought that we could only be automata on the supposition that our feehings were collateral products. Now, on the contrary, I maintain; first, that our feelings are not collateral products; sccond, that they are the active agents; and, third, that nevertheless we are automata.

This conception that feeling as agent necessarily excludes automatism is expressed by G. H. Lewes in the following paragraph :

"The question of automatism, which has been argued in the preceding chapters, may, I think, be summarily disposed of by a reference to the irresistible evidence each man carries in his own conscionsness that his actions are frequently, even if not always, determined by feelings. He is quite certain that he is not an automaton, and that his feelings are not simply collateral products of his actions, without the power of modifying and originating tlıcm."

Now in this passage there is really contained a syllogism which may be expressed as follows:

"If Feeling determines action, and is not a collateral product, we are not automata. Conscionsness proves that Feeling does determine action; ergo, we are not automata."

Now the point maintained here is, that the first 
premise is incorrect; hence the conclusion is invalid. Feeling may be the cause of physical action, and the whole be still antomatic.

If our hypothesis regarding the nature of the mind be the correct one, and feeling and physical changès be practically the same thing, it follows that one is as much the cause of physical actions as the other, and one is as automatic as the other.

It is proper to state that these are not the main reasons which $\mathrm{Mr}$. Lewes gives for rejecting the theory of automatiom. On the contrity, a large portion of his work is devoted to an elaborate exposition of his views on this question. It would carry us too far out of the way to enter into an examination of them, involving as they do questions which are far beyond the limits set for this work. Suffice it to say that Mr. Lewes devotes considerable space to a discussion of the functions of automata, and to the question whether unconscious and reflex actions are governed by Sensibility. Finding that automata have not Sensibility, and also holding that all our actions, those that are conscions and unconscions, as well as those ordinarily called reflex, are governed by Sensibility, he concludes that the human organism is not an automaton. We cannot enter into the question as to how far sensibility enters into so-called unconscions actions, as it is not essential to our argument. From our point of view it makes no difference whether the so-called uneonscions actions are guided by Sensibility or not; in either case our answer would be the same. I am realy, however, to follow Mr. Lewes some distance, and allow sensibility to many "unconscious" actions. 
As, for instance, when walking through the crowded streets we avoid the passers-by though our thoughts are deeply intent on something else. We certainly have the optical sensations of the passing crowd, and are guided by them, though at the time we are unconscious of the sensations. On the other hand, there are many reflex actions to which no subjective quality can be attached, and which cannot be governed by anything of the nature of sensibility, unless by sensibility is merely meant a neural reaction as opposed to other physical reactions, in which case the question becomes one only of terms.

Even if conscious and unconscions actions be governed by Sensibility, they may still be automatic. To be sure, a sentient action is not in oue sense of the term a mechanical one, for no mechanical toy has consciousness or sensibility of any kind. If it be maintained that nothing is automatie which has conscionsness and is worked by sensations, then we are not on this definition automata. But this limitation of the word automatism is not in my opinion essential.

When it is said that mental processes are antomatic, I do not conceive that it is necessarily meant that we are identical with or like machines in every particular. For instance, human beings grow and generate other human beings, functions not possessed by machines. When it is said that we are automata, or that our ment1] processes are antomatic, I understind that all that is meant is that our thonghts, sensations, volitions, and actions follow in certain grooves or chamels which have their analogies and equivalents in the anatomical mechanism of the brain, and that the presence of every 
state of mind is conditioned by the anatomical structure and physiological working of the brain. Automatism is then synonymous with reflex action. ${ }^{1}$ The theory of automatism is antithetical to the spiritual doctrine which postulates a central unconditioned Ego holding undisputed sway over our actions.

"But," says Mr. Lewes, "it [organized experience] cannot be made to enter into the mechanism of an antomaton, because, however complex that mechanism may be, and however capable of variety of action, it is constructed solely for definite actions on calculated lines; all its readjustments must have been foreseen, it is incapable of adjusting itself to unforeseen circumstances. Hence every interruption in the prearranged order either throws it out of gear, or brings it to a standstill. It is regulated, not self-regulating. The organism, on the contrary,-conspicuonsly so in its more complex forms,-is variable, self-regulating, incalculable. It has selective adaptation responding readily and efficiently to novel and unforeseen circumstances, acquiring new modes of combination and reaction. An automaton that will learn by experience, and adapt itself to conditions not calculated for in its construction, has yet to be made; till it is marle we must deny that organisms are machines." ${ }^{2}$ Using the same method of reasoning we may answer, such a machine his been made, not by man, it is trne, but by nature. In the human organism we find such an automaton made by natural forces.

1 Mr. Lewes admits that all mental action is reflex.

${ }^{2}$ Physical Basis of Mind, p. 48 :. 
The part which feeling plays in our action is a point of great importance, and it seems to me that it is from a failure to thoroughly grasp it that many materialists have been led into error and have lail themselves open to criticism. And, if I am right, even such an acute thinker as Professor Huxley seems to have become involved in this fallacy. "The consciousness of brutes," he says, "would appear to be related to the mechanism of their body simply as a collateral product of its working, and to be as completely without the power of modifying that working as the steam whistle, which accompanies the work of a locomotive engine, is without influence upon its machinery." Their volition, if they have any, is an emotion indicative of physical changes, not a cause of such changes. ${ }^{1}$

Again, "It scems to me that in men as in brutes there is no proof that any state of consciousness is the canse of change in the motion of matter of the organism. If these positions are well based, it follows that our mutual conditions are simply the symbols in consciousness of the changes which talie place antomatically in the organism: and that to take an extreme illustration, the feeling we call volition is not the cause of a voluntary act, but the symbol of that state of the brain which is the immediate canse of that act." ${ }^{2}$

I must be pardoned if' I dissent from so distinguished a writer. I cannot agree with the statement "that conscionsness is related to the mechanical working of the body simply as a collateral product of its working ;" nor can I admit the slightest analogy between it and

${ }^{1}$ Fortnightly Review, November, 1874.

${ }^{2}$ lbid. 
the steam whistle of a locomotive. It scems to me, if the theory of consciousness which hats been adopted in these parges be the correct one, that conscionsness has the greatest power of modifying the working of the body. That I rub my arm because I have pain there, and because I have in my mind an idea that I shall relieve that pain if I rub it, seems to me to be an incontrovertible fact. You may employ the physiological method, if you please, and by using an artifice state the fiet in physical terms instead of psychological. You may then saly that the muscular action requisite for the act of rubbing is the conscquence of molecular disturbances in the brain. This is absolutely true. But these so-called molecular disturbances are in reality conscionsucss, and hence eonsciousness is just as much the cause of the "working of the borly" as these molecular clisturbances. Any other conception than this involves a paradox.

I am unable to quite understand how it can be said that "our mental eonditions are simply the symbols in eonsciousness of the ehanges which take place antomatically in the organism," if that idea of the nature of conscionsness which I have endeavored to make intelligible in the preceling payes is elearly borne in mind.

There are only two hypotheses respecting the nature of conscionsuess which are compatible with this notion of its being a "collateral produet," and neither of these can be logically established. First, it may be supposed that eonscionsness is a distinct entity existing beyoud the physiological changes in the hrain. That when an idea is present, there are bronght into existence two things,-that which we call a physieal change plus 
something more, an jdea, and this idea is something produced or secreted. I have already shown that this is impossible; that if it were the case this idea, the second entity, must be either material or immaterial, neither of which conditions are within the bounds of probabilities. If my reasoning be not fillse, conscionsness is nothing more than the reality of these physical changes. When the brain is irritated we have feeling as a result, while physical changes are only the mode by which another person ideally perceives it.

The second hypothesis offer's the most legitimate interpretation of the doctrine we are considering, and it is the one which I believe is in hamony with Professor Iuxley's views. I do not wish to misrepresent him, but I am unable to discover in his expressed opinions any other meaning which is logically compatible with the view of "our mental conditions being only symbols in consciousness," ete.

According to this second hypothesis feeling is a "property" or "function of matter," but it must be a second function which has an existence in addition to and parallel with that function we eall physical change. Whenever physical ehange occurs, then the function of conscionsness appears side by side with it. This view has already been diseussed in Chapter I., and reasons given to show its want of validity. It hats been shown that there is nothing in the second function which cannot be as well explained through the first (physical change); it is not applicable to the law of the correlation of forees; it leads to the denial of feeling being an a tive agent in the production of our actions. Any such conclusion as this last must be an absurdity on the 
face of it. The objections urged by Dr. Carpenter and Mr. Martinean ${ }^{1}$ are well founded, namely, that it renders conscionsness superfluous, and it would neeessarily follow that all our aets and doings, both mental and physical, the greatest works of poets, the paintings of artists, and the labors of statesmen could be as well performed without consciousness as with it. This reduces such a conception to a paradox and absurdity.

This opinion, to which Professor Huxley has given expression, was apparently based on some well-known experiments on animals, and soon aroused considerable opposition and discussion. It has not appeared that the results of these experiments would warrant any such inference being drawn from them. But as whatever is said or written by this distinguished scientist has necessarily very great weight, and as these expressions in particular attracted much attention, I do not think it will be considered superfluons to take the time to consider the bearing which these experiments above referred to have on the question at issue. They, together with the phenomena of hypnotism, sommambulism, and kindred states, have thrown more light on the problems of eonseiousness than all other discoveries in nervous physiology.

A frog, from which the cerebral hemispheres have been removed, that is to say, that portion of the brain which is concerned with intelligence, volition, and the other higher facultics, is still capable of executing all the movements natural to it, under certain conditions. If such a frog, for example, be placed on the palm of the hand, and the

1 Modern Materialism, by Rev. James Martineau. 
hand then gently turned, the frog will crawl upwards on the palm till it reaches the edge, and then as the hand is still turned, it will crawl over upon the back of the hand, when this becomes uppermost, where it will remain quietly at rest if the hand is held in this horizontal position. If the hand be again slowly turned back to its original position, the frog will reverse the process till it reaches the palm where it was first placed. If again the frog be thrown into the water, it will swim like a natural frog, but will keep on swimming until exhausted or till it strikes an obstacle, when it will stop. If it strikes a board, it will crawl ont of the water on to it. If the creature be pincherl, it will hop, and if something be placed in its path, it will jump one sicle ont of the way and avoid it. If its flanks be stroked, it will eroak once for each stroke. This it will do as regularly and without fail as an engine will whistle when you pull the steam-valve. But if the creatmre be left alone, it will remain quiet for an indefinite period and make no effort to eat or move. All desire to do anything is lost. Whatever it does is done only after having been prodked.

Similar experiments have been made on other animals, on pigeons, fishes, rats, etc., and with similar results. A pigeon from which the ecrebral hemisplieres (including even the corpora striata and optic thalami, two important centres at the base of the brain) have been removel, is able still to stand on one leg. like an unmutilated bird which has gone to sleep. If left alone, it remains quiet like a dull and slecpy bird. If disturbed, it shifts its position. It dresses its feathers and tucks its lieal under its wing. If food 
be placed before it, it will not notice it, and will starve if not artificially fed; but if food be placed in its mouth, it will swallow and chew like a natural bird. If the pigeon be thrown into the air it will fly, and its flight can scarcely be distinguished from that of a normal bird. It will fly for a considerable distance and avoid obstacles. A fish thrown into the water swims like a natural fish, and avoids obstacles with considerable precision. The rabbit and rat which have been similarly mutilated run and leap. A pigeon was observed by Flonrens, who was first to experiment in this manner, to open its eyes on a pistol being fired off, "stretch its neck, raise its head, and then fall back into its former torpid attitude," but it showed no signs of fear. It sometimes followed the movements of the candle in front of it. Vulpian severed all connection between the brain and spinal cord just above the medulla oblongata in a rat; on pinching the foot the animal nttered a sharp cry of pain. "In another experiment he removed the cerebral hemispheres, the corpora striata, and the optic thalami of the rat, when it remained perfectly quict; but immediately a sound of spitting was made in imitation of that which a cat makes sometimes, it made a bound away and repeated the jump each time that the noise was made."

The actions of animals from which the brain has been removed have becn thus summarized by Onimus.

"As a summary, in the inferior animals, as in the superior animals, the removal of the cerebral hemispheres does not cause to disappear any of the movements that previously existed, only these movements assume certain peculiar characters. In the first place, 
they are more regular, they have the true normal type, for no psychical influence intervenes to modify them; the locomotive apparatus is brought into action without interferences, and one conld almost say that the ensemble of movements is the more normal than in the normal condition.

"In the second place, the movements exeented take place inevitably after certain excitations. It is a necessity that the from placed in water should swim, and that the pigeon thrown into the air should fly. The physiologist can then, at will, in an animal without the brain, determine such and such an act, limit it, arrest it; he can anticipate the movements and aftirm in advance that they will take place under certain conditions, absolutely ats the ehemist knows in advance the reactions that he will obtain in mixing certain bodies.

"Another peeuliarity in the movements that take place, when the cerebral lobes are removed, is their continuation after a first impression. On the grouml, a frog withont the brain when irritated makes, in general, two or three jumps at the most; it is rare that he makes but onc. Placed in water, it continnes the movement of natation mutil it meets with an obstacle; it is the same in the carp, cel, ete. The pigeon continues to fly, the duck and goose entimue to swim, ete. We shomld say that there is a spring which needs for its action a first impression, and which is stopped by the slightest resistance. But, what is striking, is preciocly that entinuation of the condition once determined, and we eannot refrain from connecting the facts observed in an animal deprived of the cerebral lobes with those which constitute the chanacteristic properties of inor$h$ 
ganic matter. Bronght into movement, the animal without a brain retains the movement until there is exhanstion of the conditions of movement, or until it meets with resistance; taken in repose, it remains in the state of inertia nutil an exterior canse intervenes to bring it ont of this condition. It is living, inert matter." 1

It is hardly necessary to enter into any extended discussion of these expcriments. What they show is, that the movements habitual in the lower animals, as walking, rmuing, flying, etc., as well as similar movements in man, are or may be performed withont the continuous intervention of conseiousness, ${ }^{2}$ by a mechanism at the base of the brain. In the gray ganglia at the base is contained a clock-work which is capable of carrying on these movements when once the spring has been tonched which sets it into action. The modes by which this spring may be touched are varions. It may be direetly throngh the sensory nerves without the intervention of the brain, as in the case of these experiments; in which ease all movements will be performed without the influence of volition or consciousness : or it may be

1 Flint's Physiology.

" To avoid misunderstanding, it should be stated that the term "conseiousness" is used here in connection with these experiments to indicate that special mode of consciousness called selfconsciousuess, by which we are conscions of our sensations. It is not necessary for us to enter into the question whelher these animals have any sensations or sensibility at all. What I am contending for is, that even granting they have no sensations or anything that can be imagined as a subjective state, that still they do not negative the eonelusion that in the normal state consciousness, either in its general or special form, is a causative fuctor in our aetions. 
through the brain and intellect; in which case this clock-work will be directly under the control of volition. In the former case the response will naturally be machine-like after the ecrebrum has been removed, for there will remain no force capable of modifying the reaction once begun ; inamuch as with the brain all volition and higher forms of consciousness have been destroyed. When the automatic mechanism has once begun to work, it will continue till either the clock has run down or a new stimulus to the sensory nerves has started a new reaction. But the movements which are carried on in this way are only those which are habitually performed by animals under normal conditions. The part which is normally played by that special form of consciousness called volition in all such movements, is to touch the spring and to regulate the workings of the mechanism, so as to adapt the latter to the changing wants of the organism.

While volition ean interfere and direct each movement of the body, it habitually does so only when some new or unusual movement is to be performed, or some old combination of movement is to be adapted to altered conditions. We all know that even in man for such habitual movements as walking, speaking, writing, sewing, knitting, ete, conseionsness of the muscular action employed is not neessary. We are acenstomed to perform these actions mechanieally, as we saly, without being aware of each movement we make. Consciousness simply sets in motion the mechanism at the base of the brain. In this way a division of labor is effected. If we were obliged to keep our thoughts intent upon every move- 
ment we make, our brains would soon tire, and we would have little opportunity for thought and reflection upon the matter which the movements were intended to effect. If I were obliged to keep my mind intent upon the formation of each letter as I write, I should have little opportunity for thought concerning the matter about which I write.

In this important particular, then, the animal without a brain differs from the normal animal. Thongh all possible movements ean be performed, they are not performed in the same manner as before. The animal has lost the faculty which in the normal condition modifies his movements; he has no intelligence or volition. He may be said to know nothing. The enstomary agency which guides him is gone. That agency is feeling. His past experience can serve him only so far as it has impressed itself in the meehanism at the base of the brain, and can become manifest only as a mechanieal resultant to external impressions. Though all normal movements are performed, they are so only as necessary reactions to external stimuli, and in a stereotyped manner. While the animal reacts to a stimulus, it does not reegnize what the stimulus is; it shows no fear or pleasure.

Though it is true that notwithstanding the loss of the brain, and also, therefore, of conscionsness, the animal is ealuable of movements of a complicated clialacter, yet with this loss of consciousness there is also lost that veiry modification of the movements which is peculiar to the animal possessing consciousness, and which is effected by consciousness. With the loss of consciousness there is lost also the especial manifestations of consciousness. 
These experiments, then, plainly cannot be cited in evidence of the theory that volition has no influence in modifying bodily action. When properly examined they are capable of no such interpretations. On the contrary, they show that with the removal of the brain there is brought about just such a profound derangement of bodily functions as would be expected to follow from the withdrawal of consciousness; and the results harmonize completely with our knowledge of the functions of the brain.

In these experiments it is very probable that all the actions of the animals were not only performed automatically, but withont the co-operation or even presence of any kind of conscionsuess, that is, anything like a subjective state; for the cerebral hemispheres had been removed. But in the following extraordinary case a difference of opinion has existed, and Professor Huxley in particular was led to believe from analogy with the above cases of frogs and other animals, that conscionsness was not present. The case is well known and has been frequently quoted, and I should not venture to repeat it here were it not that it has an important bearing on the question under discussion, and apparently is the principal evidence upon which Professor Huxley rests his conclusions. In this ease not only were all movements present which occur normally, but they were modified and adapted to changing conditions as in the normal state. If it can be shown, then, that they took place withont being accompanied by consciousness, a strong case is made out for Professor Huxley's side.

The anse was reported by Dr. E. Mesnet in the Union Médicale of July 21 and 23, 1874. The follow- 
ing aecount of it is taken from Maudsley's " Physiology of the Mind":

"A sergeant in the French army, aged 27 years, was wounded at the battle of Bazeilles by a bullet, which fractured the left parietal bone. He had power enough to thrust his bayonet into the Prussian soldier who wounded him, but almost at the same instant his right arm, and soon afterwards his right leg, beame paralyzed. He lost eonscionsuess, and only recovered it at the end of three weeks, when he found himself in the hospital at Mayence. Right hemiplegia was then complete.

"By the end of a year he had regained the use of his side, a shight feebleness thereof only being left. Some three or form months after the wounl, peculiar disturbances of the brain manifested themselves, which have recurred since periodieally. They usually last from fifteen to thirty hours, the somd intervals between them varying from fifteen to thirty days. These alternating phases of normal and abnormal conscionsness have continued for four years.

"In his normal condition, the sergeant is intelligent, and performs satisfactorily the duties of a hospital attendant. The transition to the abnormal state is instantaneous. There is some mneasiness or heaviness about the forehead, which he compares with the pressure of an iron band, but there are no convulsions, nor is there any ery. He becomes suddenly uneonscions of his surromdings and acts like an antomaton. His eyes are wite open, the pupils dilated, the forehead is contracter, there is incessant movement of the eyeballs and a chewing motion of the jaws. In a place to 
which he is accustomed he walks about freely as usual, but if he be put in a place unknown to him, or if an obstacle is put in his way barring his passage, he stumbles gently against it, stops, feels it with his hand, and then passes on ene side of it. He offers no resistance to being turned this way or that, but continues his walk in the way in which he is directed. He eats, drinks, smokes, walks, dresses and undresses himself, and goes to bed at his usual hours. He eats voracionsly and without discermment, scarcely chewing his fool at all, and devours all that is set before him withont showing any sitiety. General sensibility is lost, pins may be run into his body, or strong electric shoeks sent throngh it, without his evincing the least pain. The hearing is completely lost; noises made close to his ears do not affect him. The senses of taste and smell are lost; he drinks indifferently water, wine, vinegar, assafoetida, and pereeives neither good nor bad odors. The sense of sight is almost, but not quite lost; on some occasions he appears to be in some degree sensible to brilliant objects, but he is obliged to call the sense of touch to his aid in order to apprehend their nature, form, and position; they produce only valgue visual impressions, which require interpretation into the langrage of touch. The sense of touch alone persists in its integrity; it seems, indeed, to be more acute than normal, and to serve almost exclusively to mantain his. relations with the external world. When he comes ont of the attack he has no remembrance whatever of what has happened during it, and expresses the greatest surprise when told what he has done.

"Through the tactile sense, trains of ideas may be 
aronsed in his mind, which he immediately carries into action. On one oceasion, when walking in the garden under some trees, he dropped his cane, which was pieked up and put into his hand. He felt it, passing his hand several times over the curved handle, became attentive, seemed to listen, and suddenly cried ont, 'Henri,' and a little while afterwards, "There they are, at least twenty of them; we shall get the better of them!' He then put his hand behind his back, as if to get a cartridge, went through the movements of loading his musket, threw himself full length upon the grass, and concealing his head behind a tree, after the manner of a sharpshooter, followed, with his cane to his shoulder, all the movements of the enemy whom he seemed to see. This performance, provoked in the same way, was repeated on several occasions. It was probably the reproduction of an incident in the campaign in which he was wounded. 'I have found,' says Dr. Mesnet, 'that the same scene is reproduced when the patient is placed in the same conditions. It has thus been possible for me to direct the activity of my patient in accordance with a train of ideas which I could call up, by playing upon his tactile sensibility at a time when none of his other senses afforded me any communication with him.'

"All the actions of the sergeant, when in his abnormal state, are either repetitions of what he does every day, or they are exeited by the impressions which oljects make upon his tactile sense. Arriving once at the end of a corridor where there was a locked door, he passed his hands orer the door, found the handle, took hold of it and tried to open the door. Failing in 
this, he scarched for the key-hole, but there wis no key there; thereupon he passed his fingers over the screws of the lock, and endeavored to turn them, with the evident purpose of removing the loek. Just as he was about to turn away from the door, Dr. Mesnet held up before his eyes a bunch of seven or eight keys; he did not see them; they were jingled londly close to his ears, but he took no notice of them; they were then put into his hand, when he immediately took hold of them, and tried one key after another in the keyhole without finding one that would fit. Leaving the plaee, he went into one of the wards, taking on his way varions artieles, with which he filled his poekets, and at length came to a little table which was used for making the records of the ward. He pasied his hands over the table, but there was nothing on it; however, he touched the handle of a drawer, which he opened, taking out of it a pen, several sheets of paper, and : inkstand. The pen had plainly suggested the irlea of writing, for he sat down, dipped it in the ink, and began to write a letter, in whieh he recommended himself to his commanding officer for the military medal on account of his good eonduct and his bravery. There were many mistakes in the letter, but they were exactly the same mistakes in expression and orthography at he was in the habit of making when in his normal state. From the ease with which he traed the letters and follower the lines of the paper, it was evident that his sense of sight was in aletion, but this was placed beyond doubt by the interposition of a thick screen between his eyes and his hand; he continned to write at few words in a confused and almost illegible manner and 
then stopped, withont manifesting any impatience or discontent. When the screen was withdrawn, he finnished the uncompleted line and began another. Another experiment was made: water was substituted for ink. When he found that no letters were visible, he stopped, tried the tip of his pen, rubbel it on his coat-sleeve, and then began again to write with the same results. On one occasion he had taken several sheets of paper to write upon, and while he was writing on the topmost sheet, it was withdrawn quickly. He continued to write upon the second sheet as if nothing had happened, completing his sentence without interruption, and without any other expression than a slight movement of surprise. When he had written ten words on the second sheet it was removed as rapidly as the first; he finished on the third sheet the line which he had begun on the second, continuing it from the exact point where his pen was when the sheet was removed. The same thing was repeated with the third and fourth sheets, and he finished his letter at last on the fifth sheet, which contained his signature only. He then turned his eyes toward the top of this sheet, and seemed to read from the top what he had written, a movement of the lip accompanying each word; moreover, he made several corrections on the blank page, putting here a comma, there an $e$, and at another place a $t$; and each of these corrections corresponded with the position of the words that required correction on the sheets which had been withdrawn. Dr. Mesnet concludes from these experiments that sight really existed, but that it was only roused at the instance of touch, and exercised only upon those objects 
with which he was in relation through tonch. After he had finished his letter the scrgeant got up, walked down to the garden, rolled a cigarette for himself, sought for his mateh-box, lighted his cigarette, and smoked it. When the lighted match fell upon the ground, he extinguished it by putting his foot upon it. When the cigarette was finished he began to prepare another, but his tobaceo-pouch was taken away, and he sought in vain for it in all his pockets. It was offered to him, but he did not perceive it ; it was held up before his eyes, but he took no notice of it; it was thrust under his nose, but he did not smell it; when, however, it was put into his hand he took it, completed his cigarette directly, and struck a match to light it. 'This match was purposely blown out, and another lighted one was offered to him, but he did not perceive it; even when it was brought so close to his eyes as to singe a few eyelashes he did not notice it, neither did he blink. When the match was applied to his cigarette, he took no notice and made no attempt to smoke. Dr. Mesnet repeated this experiment on several occasions, and always obtained the same results. The sergeant saw his own match, but saw not the mateh which Dr. Mesnet offered to him. There was no eontraction of the pupil when the lighted match wats bronght close to the eye. He had once been employed as a singer at a café. In one of his abnormal states he was observed to hum some airs which seemed familiar to him, after which he went to his room, took from a slielf a comb and looking-glass, combel his hair, brushed his beard, adjusted his collar, and attended carcfully to his toilet. When the glass was turned round so that he only sall the 
back of it, he went on as if he still saw himself in it. On his bed there were several numbers of a periodical romance. These lie turned rapilly over, apparently not finding what he wanted. Dr. Mesnet took one of these numbers, rolled it up so as to resemble a roll of music, and put it in his hand, when he seemed satisfied, deseended the stairs, and walked aeross the court of the hospital towarls the gate. He was turned round, when he started off in the new direetion given to him, entering the lodge of the door-keeper, which opened into the hall. At this moment the sun shone brightly through a window in the lodge, and the bright light evilently suggesterl the foot-lights of the stage, for he placed himself before it, opened the roll of paper, and sang a patriotic ballad in an excellent manner. When he had finished this he sang a seeond and a third, after which he took out his handkerchief to wipe his face. A wine-glass containing a strong mixture of vinegar and water was offered to him, of which he took no notice, but when it was put in his hand he drank it off without exhibiting any sign of an unpleasant sensation. Dr. Mesnet propounds the question whether in this perfect rendering of the three ballads he heard his own voice, or whether the singing was purely as antomatie as his other actions. The attack eame to an end before they eould make an experiment to test this question. When the sergeant is in his abnormal state, it is impossible to awaken him to his normal state, whatever efforts be made. No effect is produeed either by stimulation or by strong electrieal eurrents. On one oecasion he was seized suddenly by the shoulders and thrown violently upon the grass. He manifested no 
emotion, but, after feeling the turf with his hands, raised himself again, calm and impassive.

"A remarkable feature in the case is that the sergeant becomes a veritable kleptomaniac during the attacks. He purloins everything that he can lay his hands on, and conceals what he takes under the quilt, the mattress, or elsewhere. This tendency to take and hide has shown itself in each attack. He is content with the most trifling artieles, and if he finds nothing belonging to some one else to steal, he hides, with all the appearance of secrecy, although surrounded at the time by persons observing him, various things belonging to himself, such as his knife, water, pocket-book. His other actions during an attack are repetitions of his former habits; these acts of stealing are not so."

Professor Huxley raises the question whether this man possessed conscionsness during all these performances,-i.e., whether his actions were accompanied with a corresponding train of ideas; or whether the "mind is a blank," and he is in the condition of the frogn deprived of his brain,-an automaton, "a meclianism worked by molecular changes in the nervous system." Professor Huxley, reasoning from the amalogy which he finds in the from, inclines to the latter supposition. That the man is an antomaton there can be no doubt; but I cannot anree in thinking that ideas do not aceompany his museular movements, but, on the contrary, must believe they goveru them. In the first place, as I Iuxley admits, there is nothing to "prove that he is absolutely unconscions;" and in the second place, a much stronger analogy, as Dr. Mesnet and Dr. Carpenter have pointed out, can be drawn between the performances 
of this man and those of somnambulists-who certainly do possess ideas, for they remember them afterwardsthan between them and the phenomena of the brainless frog. If the former comparison be made, the one will be found to resemble in important particulars the other; while if the sergeant be compared with the brainless frog, an essential difference in the movements of the two becomes at once apparent. In the frog deprived of his hemispheres, the actions of its museles are confined to such simple movements as swimming, jumping, and balancing itself, nearly all the motions performed by a frog in its lifetime. Consequently the lower centres are perfectly capable of regulating them. It is similar with fishes which simply swim, and pigeons which fly and dress their feathers. These actions have been so frequently repeated that the lower ganglionic centres carry them out automatically withont the intervention of eonsciousness, just as a woman knits or sews without being conscious of what she is doing, and while her thonghts are engaged on something else. And there is further this peenliarity about the brainless frogs and birds: they are absolutely machine-like in eharacter. The pigeon thrown into the air will eontinue to fly until it strikes some obstacle or falls exhausted to the grourd; the fish will swim in the same manner, and even the pigeon will starve though food be placed before it, unless artificially fed like an infant. There is lacking that quality in its actions which we call intelligence. To be sure,-a point upon which Huxley lays considerable stress, - the frog, if a book be placed before him and he be made to hop, will jump aside, carefully avoiding the obstacle. But this is one of the simplest 
of reflex actions, and similar to unconscious knitting, when sight directs the hands; though we do not perceive the stitches, an irritation is conveyed direct from retina to the optic thalamus and other centres for the co-ordination of sight and movement; from here the nervous current is reflected to the muscles of the limbs, and the animal springs in the required direction. This is a mechanism as simple as that observed in the wellknown experiment on the amputated legr of a frog, and one which has been performed thousands of times in the frog's lifetime, and thus become impressed as it were in the nervous centres. ${ }^{1}$

In man there are very few movements performed unconsciously without previous education. There are some, but they are of the simplest kind, such as winking, sncking in the infant, crying, and possibly dodging the head before an expected blow, etc. Even walking is only with difficulty acquired, and it is only after it is skilfully learned that it can be performed unconscionsly. It may be said that if a child were prevented from asing its legs till after the age at which children usually walk, his "walking-centres" might be sufficiently developed by the natural processes of growth, as with flying in birds, to allow him to walk withont education. But even so, this is not the ease with such muscular actions as, for instance, are performed by

'It may be that education is not necessary for the development of the mechanism in the lower eentres required for such simple movements. It has been shown, I helieve, that birds, for instance, do not learn to fly. If they are confined so that they cannot use their wings till after the time when hirds usmally fly, they ean fly us well ns other birls who have gone through the so-called process of education. 
telegraph operators. They sometimes acquire the art of telegraphing with such precision, that some are enabled to transmit a message while their thoughts are fixed upon something else ${ }^{1}$ that is, they do it unconseiously. A lady told me that sometimes when she finds difficulty in playing eorrectly on the piano a piece of musie, she is enabled to accomplish it by fixing her mind upon other things. But this is only after long and hard labor at practising. In fict, it is the case with all assoeiated movements of any degree of complexity in man, and probably also to a great extent in inimals, that they first must be acquired conseiously with the aid of the higher centres of ideation, before they can be performed uneonseiously ${ }^{2}$ by the lower ones. Applying this to the ease of the French sergeant, we must suppose, if conscionsness were not present, that he had repeatedly practised those actions he performed when he fancied the enemy in sight; and when he wrote his letter, he must have written those same sentences a great number of times in order to have done it unconsciously, and especially to have gone over it again to correct his mistakes, when only blank sheets of paper lay before him.

It was found that a certain amount of sight was present when associated with the sense of tonch, and that it was neeessary for guidance in writing. Now if he wrote withont any ideas being present in his mind corresponding to what he wrote, that is, absolutely mn-

I Carpenter's Mental Physiology.

${ }^{2}$ An unconscious act and an automatic act must not be confused. They are not co-extensive. An act may be antomatic and unconscious, as in walking, or it may be antomatic and conscious, as is all mental action. 
consciously, the muscular movements of his hand must have been guided by the preceding associated movements, and by the optical excitations from the letters and words he had written. The exact part played by each it is impossible to distinguish. In the case of the telegraph operator, there is required merely an association of the optical appearance of each letter with the muscular movements required to telegraph the same letter, an association which has been cemented by every telegraph operator thousands of times. But with the sergeant, for the letter to have been written unconsciously, the optical appearance of, and muscular movement necessary for, each letter must have been firmly associated with the muscular movement neerled to write each succeeding letter; in this way each word must have been united with each word, and phrase with phrase, and sentence with sentence. To have formed such an association, that same letter to his commanding officer must have been written hundreds of times.

In the case of the operator it is copying, in the other case it is composition. The latter is a most complicated affair, and never could have been done by the lower centres without long previous training. If ideas of what he was writing were present to his mind, there is no great difficulty in understanding the case. He wrote as a somnambulist writes, though he was not in possession of all his senses. Nor is there any great difficulty in the fact that he remembered what he wrote, when he read and corrected his letter on a blank sheet.

Further analysis would show mauy other facts to prove the presence of consciousness.

But there is one point which hitherto seems to have 
escaped notice, and which, to my mind, conclusively proves that the man had eonsciousness, and that his actions were governed by ideas when he read his letter, and corrected and punctuated the blank sheet of paper. What was going on in his cerebrum during this time which could have caused him to have marle the corrections? If there was not an image there, in idea, of the past composed letter, what directed the corrections? It could not have been the sight of the misspelt words, because the paper before him was blank. It may be said the movements of his lips, which accompanied the re-reading of the letter, by association, regulated the correetion. But this is merely suspending the world upon the elephant, for we have then to account for the movement of the lips. But admitting it for the moment as sufficient, it is hardly possible that such muscular movements could have indicated the misspelling of a word unless the $i d e c$ of the word was present to his mind. Nor would this be a satisfictory explanation for the insertion of the punctuation marks. There is no movement of the lips corresponding to a comma. How could the lips indicate there was no comma there? The only satisfactory explanation that can be offered is that the ideas which were expressed on paper actually were present to his mind; or, in other words, he possessed consciousness.

But if conscionsness was present, there is nothing to show that it was not the active agent in the production of his actions. On the contrary, there is every evidence to prove that it was. All evidence, then, on the experimental sicle, tending to show that feeling is not the cause of our actions, falls to the ground. 


\section{CHA PTER III.}

\section{SELF-DETERMINATION.}

There is one objection which is sure to be raised against the views which have been argued in the preceding pages, to the consideration of which I propose to devote this chapter. This olyjection is one which hats been urged, and it must be confessed with much truth, against every other theory of antomatism. It arises from a fear that in some way or other a limitation will be set to the freedom of human thought. If any doctrine of automatism is inconsistent with any fict that is established directly by conscionsiness, it is evidence that there is a flaw somewhere in the logie. A doctrine to be sufficient must explain all the facts, whether those facts be physical or mental. If it does not do so, it is not sufficient.

I propose now to consider whether there is any fict on the side of "self-determination" with which that view of antomatism which has been adopted in this work is opposed, and if there are any gronnds for the fear that our mental liberty is in some way abridged by it. I may saly here, in parenthesis, that any mental freedom we may have, we have; and no doctrine, as a doctrine, can abridge it, and no asseveration can give us whit we have not got.

It will be my purpose to show that alutomatism after all is not a very terrible thing, and that when properly 
understood it contains nothing that is not reconcilable with popular notions regarding mental freedom. Its apparent inconsistency with that power, which each individual feels and knows he has, will be found to be only a bughear with which to frighten the unthoughtful, and when carefully examined will be made to reveal its skeleton nature.

If by self-determination is meant the ability to dircet our attention in one way more than another, to keep onr thoughts occupied with one class of facts to the exclusion of other:, and to make a choice when two courses of action are open to us, I know of no evidence which conld be more cogrent than that which we already possess pointing to the possession of such a power. I agree with Dr. Carpenter that the evidence of our own conscionsness in this respect is sufficient and decisive. That I can direct my attention on any particular subject to the exclusion of other subject;, provided, of course, the circumistanees under which I make the trial are not those of great excitement, is a fact of consciousness, which I can demonstrate as often as I choose to try. Each one has sufficient evidence in his own conscionsness to show not only that he has the power to direct his attention, and to make a choice, when two courses of action are open to him, lut that he doesodirect his thonghts, and does make such choice; provided, howerer, and this proviso is of great importance, he has a sufficient motive to do so. For the evidence of conscionsness is equally cogent in deciding that in thus directing the comrse of his thoughts and making his choice it is the preponderance of motives which determines him. In this there is nothing that 
is incompatible either with the view herein maintained of the nature of mind, nor of the antomatic character of ideas. It is only inconsistent with that eruder form of automatism which regards our artions as simply the resultant of the bodily meehanism, and makes our thoughts mere by-produets, without influence upon such actions. Such a theory of antomatisin conld only arise from the crudest notions of the relation between the mind and the body.

But after having established the power of self-determination, the ageney by which this is accomplished is a seeond and further question. We say that we have this power of determining our actions; but what dowe understand by this term we? If by it is meant, as seems to be by Dr. Carpenter, Archbishop Manning, and others, not only "another ficulty, but, more than this, another agent, distinct from the thinking brain," which direets the working of our mind and body, then something is assumed which our conscions experience can no longer be evoked to establish. We know by direct conscionsness that our thoughts ean be determined in this or that direction, according to certain previous desires. But I know of no ennscionsess which direetly informs us of the manner in which this is done, and still less of an extra Ego orer and above our states of conscionsness, which pliys with our thoughts as it would at ninepins. I ean imagine a distinet "ficulty" of the mind, which is asociated with and regulates the other states of mind, but such at faculty must be only some state of the miml itsolf'; so that the conditions would simply be e puivalent to at state of eonscionsuess acting on all other states. The 
probability of there being such faculty is another question, which I am not discussing. I know of no evidence for it, and still less for an extra independent Ego. In my judgment, the only way in which we ean ascertain the mechanism by which this self-determination is accomplished is to study and analyze that feeling of personality commonly called the Ego, which each individual has. When we make nse of the expressions "we," "you," etc., for the orlinary purposes of social life, our meaning is plain enough, and it would be mere pedantry to ask for a precise definition; we should undoubtedly set any one down for an unmitigated bore who should interrupt us with a demand for a philosophical explanation. But in questions of this kind involving the deeper strata of human knowledge, it is not only not superfluous, but absolutely essential to define exactly what is meant by every term used, when susceptible of different interpretations. Now there are several conceptions which may be formed of the Egro.

There is the idea of an "agent distinct from the thinking brain," which directs onr processes of thought and bodily actions, and to which a sort of ownership is given over all the individual portions of the body, and the mental faculties. For any such agent as this there is no evidence whatsoever. It is merely an abstract notion, the result of an artifice of thought, and has no existence. Therefore, under such a conception, the phrase "we have a self-letermining power" is philosophically empty of meaning.

Another idea of the Egro comprehends the body and the mind united together into a whole. No particular state of mind is thought of as differentiated from the 
rest, but all possible states of mind united as an abstract notion to a body. This is much like the conception we form of another person's personality, a sort of objective Fgo. We have a notion of his body, and we imagine an abstract mind, similar to our own, conneeted with it. We have in our thouglits no particular state of mind, as an agent, acting on the individual's body, but an abstract mind.

Another similar but less comprehensive notion of this personality is mind as a whole in distinction from the body. Both of these conceptions of the Ego are too abstract to serve the purposes of this inquiry.

That interpretation of this feeling of personality, which I conceive to be the correct one, is, that it is a compound of any given dominant state of conscionsness that may be present at any moment, and other faint revived former states, and a whole stream of faint impressions more or less simultaneously coming from the periphery of the body. These last are more or less constant. I take it that consciousness at any given moment of time, where the feeling of personality is present, is always partly made up of these impressions streaming in from the periphery and constituting our eonseionsness of the body. On the other hand, there are times when we have absolutely no fecling of an Ego. Such times are those of deep thought or revery. In stulying my own conscionsness at such times (hy recalling them of course afterwards to memory) I (amnot recall any feeling of personality whatever. All eonscionsmess of surommlings, of my own borly, of my own Ego, disalperal's. I can afterwards only recell surecesive idcats following one another automatically withont reference to the sur- 
roundings, without even any sensations from my body. Afterwards when I come to myself, as the saying goes, these successive ideas are revived faintly as memory and become joined with my now dominant state of consciousness. This latter now is also reinforced by the stream of sensations from the different portions of the body. These sensations are identical with those which have been nearly constantly experienced, and constitute my knowledge of my body. With the dominant active state of conscionsness are also associated many other faint ideas or remembrances of former states. Consequently every state of consciousness where this feeling of personality is present is a compound one, consisting partly of former states revived and partly of new ones, and in many cases the new ones are but recombinations of old ones. It is from this that the feeling of personality arises, as it seems to me. Every state of conscionsness being connected with other states, some of which (sensations) are constantly or nearly constantly present, they all seem to belong to each other and to constitute a whole or Egro, and this Ego is always felt to be the same Ego, because part of its complex composition always is the same, and its elements as elements are the same. ${ }^{1}$

The whole mental process is undoubtedly a very complex one, with many variations, and it is almost impossible to completely analyze it. An illustration will give an idea of the principle which I conceive underlies this sense of the Ego.

I I have an impression that a somewhat similar explanation has been given by Clifford, but I have not his works by me to verify it. 
I am sitting in my study of a hot day, writing. I soon feel thirsty. This feeling grows on me till I think of satisfying my desire. It becomes my dominant idea. I now remember a pitcher of water standing on the table opposite, and impressed by this idea and the effect which I imagine will result if I pour out a glass of water and drink it, I proceed to earry the latter into effect. Here is a comparatively simple and yet very complex state of affairs. Now how does the sense of the Ego arise out of these various states of consciousness? I conceive it to be in this way.

The dominant and virid irlea "in my mind," that is, among a complex group of ideas, is the sensation of thirst. This sensation does not stand alone, but is joined to other sensations from my month and throat, which are the same sensations as have been constantly present before. (For that matter, the sensation of thirst is the same sensation of ten previously present in conscionsness, but now re-excited, just as the molecular disturbances underlying it are re-excited in the same manner that they have been before.) Other sensations from the surface of the body, the same that have been experienced before, now reinforce the others. Besides this, sensations from my surroundings in my study, the same that have time and again, like the others, formed a portion of my states of conscience, are now added to my present complex state. Most of these sensations are not only like but identical with previously present sensations, which latter are simply revivel. Now all these different sensations compounded together give the sense of personality, or the Ego, and the now dominant sensation of thirst being added, I say, $I$ am thirsty. 
This new sensation becomes incorporated in the group, to which other sensations, to be in turn dominant, may be added, as, again, warmtl. I say, $I$ am warm, the feeling of warmth being added to a group, in which the feeling of thirst now forms an element as a faintly revived state.

Such being the complex ont of which the sense of personality is formed, it becomes requisite to ask which is the active agent in all this in determining action. It is undoubtedly the vivid, active state, modified more or less by the circumstances of the case. The sensation of thirst, for example, is the active agent determining me to drink some water and to the performance of the requisite actions. The method I employ to satisfy my thirst would be modified by the other elements of my complex state of conscionsness, these varying with the surroundings, the time of day, and other associated ideas.

It is this complex state, then, which constitutes the Ego, and henee, as a whole, the determining agent, though some of its elements are more active than others in accomplishing the result. The most vivid and dominant element, as the feeling of thirst in the above illustration, might be regarded as the driving power, while thic associated elements are the steering-gear which regwhates the action.

Now in this matter of self-determination, if it be said that the Ego-being a complex state of conscionsnessdetermines another state of consciousness that may be alssociated with it, with or without, as the case may be, its accompanying muscular action, the proposition is a truism which cannot be gatinsaid. In this sense we certainly have self-determination, for the indueing state 
of conscionsness is as much a part of self as the sueceding one that is determined by it.

But if, on the other hand, it be asserted that the state of consciousness called the Egro can determine any other state which is not in any way associated with it, and imespective of all former experience by which ideas are associated, then something is maintained which is entirely contrary to all experience and indefensible. It eannot be denied that it is possible for ns to act in any" particular manner, provided that that idea, which is directly connected with and the precursor of the action in question, is present in eonscionsuess, howsoner it may arise. In this sense we have self-letermination, for this idea determines action. But manifestly no idea can oceasion another idea, or bolily action, which is not connerted with it; nor (an any given state of mind or bodily action oenr when the state of eon-cion-ness present is one far removel from the one in question. Furthermore, it is self-evident that no ideat can alrise spentaneonsly. Every idea is emplitioned by some previous idea or stimulus, and forms a link in a chain of events.

Now if an idea which determines an action is itself determined by a preveding idea, which in turn can be traced to a still carlicr one, and so on ladek through a elatin of such ideas, motil finally we arrive at a sensony stimulus of some linel, it would secm phainly evilent that the final action is determined indioedly thomgh a sucession of idleats by the primaly stimulus. lintthermore, it would seem that, il no disturbing element

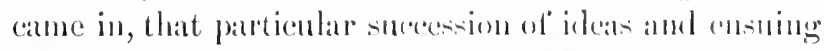
action must result, amel no other. Sow this is all the 
reflex theory demands, and in this there is nothing that the most extreme defencler of self-determination may not concede. But if the still further claim be made that self-determination is effected by an "agent distinct from the thinking brain," by something that is independent of our other conscious states, and is not governed by the same laws as other states of conseionsness, then something is asserted which eamnot be substantiated, and which must lie outside the region of experience, and be therefore mnknowable. For there is nothing in our conscious experience which directly gives us eognition of this agent, nor anything that necessitates one hypotheeating it as an explanation of known facts. Whether that interpretation of the sense of personality which I have offered be the correct one, or whether this sense arises from some other combination of mental factors, there are no more grounds for the assumption of an autocratic Ego than there formerly was for assuming a spiritual entity for an explanation of mind.

The question may very pertinently be asked, What manner of thing is this Ego? Is it something akin to that conseiousness which we know is the reality of the phenomena of matter, or is it something essentially foreign in its nature? If the former, why, it may be asked, is it not subjeet to the same laws that govern other states of conseionsness? if the latter, it must be far beyond our ken, and the old problem becomes practically reproduced, how ean it act upon the reality of matter?

From a physiological point of view, this extreme form of self-determination is equivalent to saying that "we" can divert the neural current which naturally 
would flow in one cireuit into a different circuit, irrespective of the intensity of the molecular action, and the anatomical and physiological connections in the brain. This seems to me incomprehensible.

There is one thing which must not be overlooked, and this is, that whatever powers of self-determination we may have, every action is determined by the strongest motive. However we may act, we cannot act contrary to the strongest motive; for the moment we conclude to act in opposition to what was the strongest motive, the new motive, whatever it be, if it be only the desire to show that we have the power to do so, becomes the strongest motive, overwhehming the preceling and determining action. Whatever motive determines, action is the strongest,--else it would not so determine us, - and we are compelled to act accorling to it.

When we analyze our thoughts it is not always easy to make out their automatic charaeter, so eomplicated is any mental action which involves any reasoning process except of the simplest kind. If we examine those mental actions which are admitted to be antomatic, as when one suddenly eries out on being struck, or, to take a more elaborate cxample, when a school-boy recites long rules which he has learned by heart from his Latin grammar, we shall find the distingnishing characteristic to be the absence of deliberation. In fact, in many such eases the moment we deliberate we are lost. The school-boy, too, often cannot tell whether any griven word is contained in a list without beginning with the first and repeating them in order.

When one idea follows another without ronseions effort on our part, without that special fecling called 
volition, the mental action is said to be automatic; while when we have a feeling of volitional effort, or are conscious of what is called deliberation, our thoughts are deelared to be antomatic.

But if the reasoning which has been adduced in these pages be correct, this distinction is merely artificial; from the lowest form of mental action to the highest a gradual transition may be traced, showing that there is no difference in kind, but only one of degree. Examples of this action of the mind, when the antomatic character of the ideas is plainly discernible, are more or less common in every individual, though to some they are to a large extent habitual. When we fall into day-dreams and reveries, it is very easy to recognize the automatic character of our thoughts, one follows another in natural succession, according to a previous association. On the other hand, it requires considerable introspective skill to recognize the same principle in that state of mind called deliberation, wherein the ideas, instead of following one another in progressive series without return to the original and fundamental thought, continually diverge from and return to this as a centre; thus encircling, as it were, the latter, approaching it on all sides only to leave it again by every path of ideas that may be joined by the bonds of association with it. Each "lead" of thoughts is followed, as if to see whither it goes and if it will bring us to the desired end. Just as in trying to disentangle a snarl of thread we follow each loop in tum, hoping to find the one which will unbind the whole, so in deliberation we follow each train of ideas that is associated with the central 
thought in the endeavor to find the one that will solve the problem.

Between these two modes of activity-Revery and Deliberation-there is every possible degree of transition, one gradually shating into the other, and it is impossible to say where one begins and the other cnds. The exalted form of the plainly discernible antomatic action may often be seen in the mental activity of men of genius, in whom it is more or less habitual. Coleridge and Mozart were particnlarly interesting examples. The former's flow of talk has been deseribed as only thinking aloud, and his whole life as only a waking dream. His thouglits ran on withont regard to anything or anybody, heelless of interruption, while his words were only the expression of every associated and reflected idea. Mozart's genius was essentially antomatic, as can be seen from the following account of his method of working: ${ }^{1}$

"You say you should like to know my way of composing, and what method I follow in writing works of some extent. I can really say no more on the subjeet than the following, for I myself know no more about it, and cannot aceount for it. When I am, as it were, sompletely myself, entirely alone, and of good cheer, say travelling in a carriage or walking after a good meal, or during the night when I cannot sleep, it is on such oceations that my ide:ts flow best and most albundantly. Whence and how they come I know not, nor can I force them. Those illeas that please me I retain

I See Dr. Carpenter's "Mental Physiology" for an interesting aceount of the automatic character of Coleridge and Mozart's minds. 
in my memory, and am accustomed (as I have been told) to hum them to myself. If I continue in this way, it soon oceurs to me how I may turn this or that morecan to aceount, so as to make a good dish of it,- that is to say, agreeably to the rules of counter-point, to the peculiarities of the various instruments, ete.

"All this fires my soul, and, provided I am not disturbed, my subject enlarges itself, hecomes methodized and defined, and the whole, though it be long, stands alnost complete and finished in my mind, so that I can survey it like a fine picture, or a beantiful statue, at a glanee. Nor do I hear in my imagination the parts successively, but I hear them, as it were, all at onee. What a clelight this is I camnot tell! All this inventing, this pondering, takes place in a pleasing, lively dream. Still the actual hearing of the tout cuscmble is, after all, the best. What has been thus produced I do not easily forget, and this is perhaps the best gift I have my Divine Maker to thank for.

"When I proceed to write down my ideas, I take out of the bag of my memory, if I may use that phrase, what has previously been colleeted into it in the way I lave mentioned. For this reason the committing to baper is done asily enongh, for everything is, as I have said hefore, already finished, and it marely differs on paper from what it was in my imagination. At this ocupation I can therefore suffer myself to be disturbed ; for, whatever may be groing on around me, I write and even talk, but only of fowls and geese, or of Gretie or Barbie, or some such matters. But why my productions take from my hand that particular form and style that makes them M[osertixh, and different from 
the works of other composers, is probably owing to the same cause which renders my nose so, or so large, so aquiline, or, in short, makes it Mozart's, and different from that of other people. For I really do not study or aim at any originality; I should, in fict, not be able to describe in what mine consists, though I think it quite natural that persous who have really an individnal appearance of their own are also differently organized from others, both externally and internally. At least I know that I have not constituted myself either one way or another."-Holmes's Life of Mozart, p. 318.1

'This necessary dependence of the brain upon external stimuli for thought is well observed in social society. It is this need which draws human beings together and makes man a social animal. It is to these influences that are due the charms of conversation and the pleasures to be obtained from lectures and at the theatre; and it may be said that it is upon its emotional influence that religion depends for its power. It is through this stimulation of the mind, the awakening into life of the dormant cells of the brain, that we find delight in books, in works of art, and music. It is for the want of this that the horrors of solitude consist; we need something to stimulate our minds. This we find in our friendship with men, in literature, in seience. They awakeu a reaction within us and give us life. By their help we can elevate the mind to the highest stages of development; by their complete withlrawal it is possible to produce perfect idiocy. And just as our

${ }^{1}$ Quoted by Carpenter. Op. eit., p. 272.

a $\quad k$ 
muscles, from lack of use, will wither away and become useless, so will our minds under the same circumstances degenerate and become vacint; and it may be said in general that as the brain in its lowest form of development recognizes only sensation, and in its highest evolves ideas, that brain is, cxteris paribus, the most highly developed which is capable of responding to few thoughts of others with many of its own.

It may not be unnecessary to caution the reader not to confound this question of self-determination with that of moral responsibility. It may be thought, at first sight, that they are identical. But this is not the case. Responsibility depends upon many other factors, which are beyond my purpose to consider here.

There are, undoubtedly, many persons who, simply from conservative habits of thonght, will be mable to accept the views which have been set forth in the prececling chapters. The opinions of many such are too firmly moulded by time and education to allow them to change, no matter how irrefrangible the evidence offered, and they must die in the beliefs in which they were born. Others there are who, though anxious for truth and ready to inquire into all domains of knowledge, may likewise be deterred, not so much from conservatism as by a fear that in some way the acceptance of a doctrine may lead to a limitation of mental freedom. Just as there are many persons who refuse to accept the demonstrated truths of evolution, not because of the insufficient evidence of the truth, but from a fear that some of their religions creeds may be overthrown. This sensitiveness from religious scruples 
in the acceptance of scientific doctrines, which is so marked in all departments of science, is particularly active in inquiries into the problems offered by the Mind. For myself, while I am able to recognize the force of conservatism, I am mable to understand how any right-minded person, how any one who truly seeks after knowledge, ean have any sympathy with those who refuse to accept a doctrine, however strong may be the evidence on which it is based, simply from fear that when carried to its logical consequences, it may antagonize preconceived notions. The only thing to be dreaded in all such inquiries is that self-deception to which the human mind is prone. I believe our aim should be to seek the truth, and as long as we can be assured we are on the right road, we should pursue it wherever it may lead, and whatever may be the result. And if it should happen that the conclusions to which we are led are not in harmony with the popular views of the day, thongh the fact may be regretted, our results should not for that reason be discarded.

In advocating that explanation of nervous phenomena which has been maintained in the preceding chapters, I have been actuated by the conviction that "that theory is most deserving of credence which explains the greatest number of known facts," and I believe it has at least the merit of being free from the mysticism with which all other doctrines are obscured. One by one the old supernatural agents have been weeded out of our philosophies. Formerly, whatever in nature was beyond the comprehension of the times was considered to have a spiritual cause. Whatever could not be understood was accounted for by an es- 
sence. Wool burned because the essence fire entered into the substance. Water was fluid because the essence aquosity permeated matter. Gradually, however, as science advanced, these essences have been gotten rid of one by one, and now but onc remains. This is mind. This, in its tum, must go. It only remains to decide whether it shall be to-day or to-morrow. 


\section{CHAPTER IV.}

\section{WHAT IS MATERIALISM?}

"But, as I have eudeavored to explain on other occasions," says Professor Huxley, "I really have no elaim to rank myself among fatalistic, materialistic, or atheistie philosophers. Not among fatalists, for I take the conception of necessity to have a logical and not a physical foumdation; not among materialists, for I am utterly incapable of conceiving the existence of matter if there is no mind in which to picture that existence; not among atheists, for the problem of the ultimate cause of existence is one which seems to me to be hopelessly ont of reach of my poor powers." 1 And "we antimaterialists," cries Mr. Fiske, in the midst of his uncalled-for vituperation against materialism. Yet Huxley remarks that "thought is as mueh a function of matter as motion is," 2 and Mr. Fiske's position is very much the same as that of others who eall themselves materialists. What, then, is materialism?

The term materialism has no definite and determined meaning. As soon as the spiritualistic hypothesis was abandoned as untenable, and it was seen, on scientifie as well as philosophical grounds, that the forees of nature were sufficient to aceount for the facts of conscionsness as well as for that which is unconseions

1 Fortnightly lieview, November, 1874.

${ }^{2}$ Lay Sermons and Addresses, p. :338. 
in nature, all sorts of interpretations sprung up and were adopted as explanations of mental facts. While the thoughtful were slow to formulate any positive opinions as to the exact conditions of the problem, others, more hasty and less philosophical, have not hesitated to advance erude and ill-digested dogrnas as explanations of the mental world. But all opinions, those of the vulgar and ignorant as well as those of the learned, have been elassed together, without discrimination, as modern materialism. What is still worse, the opponents of the new philosophy, without stopping to distinguish between the good and the bad, the sound and the unsound, have at times seized upon the most extreme and unsound doctrines, advaneed by the hasty and irresponsible followers of the leaders in thought, and held them up to the public gaze as representative of modern materialism. Not only such unfounded doctrines as these, but their own illogical deductions from scientific truths, which they eould not, or, what is to be feared is often the ease, they would not understand, have been ascribed to those who do not hold them. Nor have the opponents of materialism taken the trouble to properly study and understand the true position of modern science, but falling upon some accidental inexactness of expression, have employed it as a text to assail opinions which were never maintained. It does not make the mode of attack any the less dishonest that those who have made it have stood high in public estimation. A false materialism has thus been ereated, the origin of which is to be found alone in the minds of those who have set themselves up as the champions of the public virtue. 
The term materialism has cone to be elothed with a meaning which does not belong to it, and has been used simply as a term of vituperation and abuse. This has led the real exponents of the doctrine to repudiate opinions to which false meanings have been attached, and which have been often wilfully misunderstood.

What, then, is a materialist?

I conceive that there are two positions upon either one of which we must stand, and between which there is no half-way restiug-place. Either all the facts of nature with which we are conversant-both those of the subjective world of thought and of the objective world of things about us-are to be referred to natural forces for their explanation, or one class of facts, the subjective, are to be ascribed to a supernatural agent, leaving the objective world of things for natural forces alone. The former, under whatever interpretation it is presented, is materialism ; the latter is spiritualism. We must accept cither one or the other.

To show that matter is not what it is supposed to be by the vulgar and ignorant, that it is something far removed from the orlinary conception of it, is not to remove it in any way from the field of materialism. Nor by arbitrarily limiting the term "matter" to the appearances of objects, and identifying those fuets which we call mind with that substratum underlying these appearances, have we in any way avoided the consequences of materialism. Showing that this substratum is not tables and eliairs and sticks and stones as we know them, is not to remove it from the material world and place it in the spiritual worlel; to do so is to invest spiritualism with a meaning which it does not 
possess; and yet this, if I do not misunderstand him, is practically the position of Mr. Fiske. I dislike very much to ascribe opinions to any writer for fear of misrepresenting him, and therefore I speak, as $\mathrm{Mr}$. Fiske himself has said, "subject to correction," and I am the more timid in this respeet beeause the history of philosophy has showu that it is the peculiar fate of writers on abstruse subjects to be misunderstood.

As long as anything is the resultant of the forces of nature it belongs to materialism. Spiritualism, on the other hand, has always been understood to refer to something that is supernatural and is not conditioned by the laws of nature. To show, then, that matter is something else than what we have supposed it to be, is not to remove it to the realms of spiritnalism, for it is still something which is conditioned by natural laws. And consequently because we have reason to believe that mind is identical with this real matter (or an "aspect" (?) of it), and is not identical with the vulgar conception of matter, we do not in any way escape from the bonds of materialism. Every one knows that thonght is not stones, or sticks, or horses, or dogs, or even physical vibrations, or neural undulations; "it needs no ghost (or philosopher), my lord, to tell us this." But thought may be identical with the substratum underlying certain physical vibrations, and any doctrine which accepts this, express it in any words you please, is materialism. Any doctrine which rests content with nature, and does not introduce any supernatural element, is materiali $-m$.

By showing that there is something in nature more potent than we have ever conceived of, something 
which is beyond the powers of our poor senses to apprehend in its reality, materialism elevates our conception of matter and our appreciation of the powers of nature. This is a sufficient task. Unfortunately, we have all been taught to look. upon matter as something inert and base. In this we have seen only with our eyes, and have not looked behind the appearances of things. Behind them nature herself lies concealed, and when she has shown herself to us in her nakedness and withont disguise in the form of our thoughts, we have failed to recognize her, and mistaken her for a supernatural goblin.

We now know, thanks to science and philosophy, that matter is no longer the dead and senseless thing it is popularly supposed to be. We know that the socalled properties of matter, the shape, the color, the hardness, and other qualities of objects, do not exist outside of our own minds, but that objects as known to us are merely forms of our own consciousness. Yet, though this be true, we also know that besiles these forms of our own conscionsness, there is something else, which exists outside of them, and is the cause of them; that this something else consists of "activities" or "forces" of an unknown nature, and that these activities constitute the real object, the thing-initself. Objects, as we know them, are only sensations or modes of consciousness by which we apprehend these external activities, or, in other words, the reaction of our organism to these forees.

Matter, then, may embrace at least two conc ptions (page 33), subjective matter and objective matter,the latter being the real thing, though unknown. 
Though we cannot picture to our minds the nature of these external forces, which must be forever unknown to us, Evolution teaches us that they must be allied in nature to conscionsness. The clcmental forces which underlie the functions of the organic world are the same as those which underlie the properties of the inorganic world. The reality of the carbon atom is the same whether it occur combined with two atoms of oxygen simply in the form of earbonic acid gas, or whether it be joined with many atoms of carbon, oxygen, hydrogen, and nitrogen in the form of a molecule of vital protoplasm. And the difference of properties and functions depends upon the greater or less complexity of the groupings of the elemental Rcalities. Finally, as we ascend in the scale of animal life, by more complex grouping of these elemental forees the first germs of consciousness arise, which reaches its highest development in the brain of man. ${ }^{1}$

The whole universe, then, instead of being inert is made up of living forces; not conscious, because consciousness does not result till a certain complexity of organization appears, but, using figurative language, it may be said to be psendo-conscions. It is made up of the elements of conscionsuess. It is to these forces that are duc the phenomena of the inorganic world, of life and of Mind. And when we reduce the problems of life and mind to terms of this matter, we deal with materialism. Any doctrine which recognizes these truths in this or some modified form still remains, in my

See note to page 49 . Clifford, I think, was the tirst to clearly reeognize and formulate this principle, though grlimpses of it may have been caught by others. 
judgment, materialism. Matter is elevated to a higher rank, but it is still matter.

But after everything has been reduced to its lowest terms, after everything has been shown to be dependent upon the inherent forces of nature and the resultant of material conditions, have the dignity and attributes of anything that exists been in any way detracted from? Because man has been shown to be the last and highest expression in the order of development of nature, and the final resultant of those natural forces which have produced all other forms of life, have his diguity and powers as man been in any way impaired? And because mind, the chef d'cutve of creation and final product of vital forces has been shown to be the outcome of the same material conditions as other vital phenomena, have its qualities been in any way impaired" Though science and philosophy may discover the causation and origin of phenomena, it camnot by so doing alter by a hair's breadth those phenomena themselves and make them what they are not. We may determine the elements of which any given product is composed, and ascertain the conditions by which it has arisen, but we cannot through such an analysis show that product to be anything else than what it is. The direction and energy of any force is not in any way changed by the discovery of the elementary forces of which it is the resultant.

Is the sparlile of a diamond any the less brilliant, or is the stone less valuable, because the ehemist tells us, as a result of his analysis, it is nothing but carbon? The pessimist maly tell us from the gloom of his halffledged materialism that Raphacl's great picture, the 
Sistine Madonna, is after all nothing but paint and canvas, nothing but a conglomeration of yellow ochre, and Prussian blue, and copper green and red, spread upon some twisted and interwoven strands of flax. But after he has told us this, interesting possibly from a technical point of view if we did not know it before, he has not in any way detracted from the beanty of the pieture. The picture is not yellow ochre nor Prussian blue, nor any other of these elements he hats detailed, but the resultant of their combined properties, so combined that the final product is the materialized image of the great artist's conception fixed indelibly for all time. Yon may analyze the substance of the work till you have reduced it to its lowest chemical and physical terms, to a final conglomeration of atoms, but when you have finished there stands the pieture as beautiful and as grand as ever, maltered in a single line by your analysis and its color undimmed in a single spot. The picture is what it is, no matter what the elements may be which compose its substance; the resultant of all these forees is the picture, the finished whole.

And so it is with man. By showing that man has been slowly evolved through natural forces from the lowest forms of animal life, his powers and qualities as man have not been impaired in a single respeet. There are some who far, because the tradition has been outgrown whereby man came upon the earth as a sudden and miraculous act of creation and was deposited in a paradise where everything was prepared for his wants, that thereby his dignity as man is in some way detracted from. Just as there are some people who, 
though by their superior alilities they have raised themselves above their fellow-beings and surpassed them in the race of life, are nevertheless ashamed of the lowly position from which they started ; forgetting that this very fact proves their snperiority and renders their talents more conspicnous. It is this very disadvantage at the begimning which should make thrm more prond of their success at the end. And so in the progress of evolntion on this world, the fact that min is the highest and culminating expression of nature should render us prond of onr pre-eminence and of the exalted position we oecupy.

And when we pass to those faculties which distinguish man from all other forms of ereation, and make him facile princeps,- - his mental eharacteristies,-are his intellectual or moral qualities in any way belittled when it is diseovered that these qualities are also the products of natural forees, and are the result of the laws of evolution? Though we may show that the highest flights of the intellect, the dramas of Shakespeare, the great Cathedral of St. Peter of Michael Angelo, and the Madonna of Raphlael, are but the expression of natural forces, we do not in any way detract from the grandeur and beanty of the work. Nor is the greatness of moral laws in any way impaired by the diseovery that they also owe their existence to the slow forees of evolution, and have been dependent upon the organic development of the brain. Thongh their germs may be found in the psycholngical and physiological laws governing the lowest races of mankind, nay, further, in the lower orders of animals, the moral laws themselves are as dominant and sublime as thongh 
they were the express laws of a Creator given alone to man in his most developed state.

"Do not unto others what ye would not that they should do unto you" is no less grand in its conception because it is the resultant of material conditions. The lover will not sigh any the less "like a furnace" becanse yon inform him his love is only the reality of molecular disturbances in his brain. We do not in any way soften the grief of the mother who mourns the loss of her first-born by telling her that her grief is the product of material factors, nor is our sympathy in any way lessened by the knowledge. She will tell you she knows nothing of all this, only that the life that is gone will never return again.

Our thoughts, our feelings, onr hopes, onr griefs, our pleasures, and our pains are the same and as we know them, whether their origin be found in matter or in a spirit.

But there is one respect in which materialism is far more elevating than any other doctrine. It is this. Though materialism may, in the opinion of some people, degrade man from the lofty position which, in his pride and arrogance, he had assumed for himself, and relegate him to a lowlier one at the head of the brute creation, it, on the other hand, elevates the latter to a higher station and extends the hand of sympathy to suffering, whether in man or animal. Materialism teaches us that the animals, though not so highly developed as ourselves, still differ from us only in legree, however great that degree may be. It teaches us that though their thoughts may not be as complex and extensive as our own, they still have thoughts. That 
they have emotions and sensations, pleasures and pains, like ourselves, and the lash of the whip stings as smartly as when applied to our own backs.

Materialism teaches us that, however lowly, they belong to our kith and kin, and though it may be necessary and proper that man should hold dominion over them, it should be exercised with clemency and diserimination. There can be no doubt that the belief that man is not only superior to the brute, but belongs to a supernatural order of beings, has tended to lessen our sympathy for these lower forms of creation, and blunt our sensibilities regarding them. The belief has beeome too general that the animal is not only a machine, but an insensible maehine, and it too often happens that our sympathy remains untouched, even though the dog may lick the hand that slays it with the knife.

Nor will the morality of materialism compare unfavorably with that of any other philosophy. Materialism does not destroy morality, it merely seeks a new souree for its origin. It is a fact, which no amount of analysis or scientifie investigation can negative, that we have in us eertain ideas and feelings, which we eall principles,-moral principles. You may eall these laws of thought if you please, but the elass to which they belong we eall moral. Under any other name they would be as real and as influential in determining om actions as that designated by the term morality. It is an interesting study to inquire into the conditions which have given rise to thesc laws of thought, and this science does, by investigating not only human nature as it existed in historie and, so far as is pos- 
sible, in prehistoric times, and attempting to follow its development step by step to the present time, however imperfectly this can be done, but also by a comparative study of the lower animals, and of the numerous savage and lower races of men which inhabit the various portions of the earth to-day. As moral laws are really psychological laws, this becomes a comparative and historical psychology.

While the spiritualist accounts for these laws on the principle of intuition, or, in other words, by presupposing the existence of innate ideas of right and wrong, duty, etc., which, already developed and perfected, have been implanted in the mind by a Creator, the scientific inquirer after truth, rejecting any such lazy and unintelligent method of explaining the origin of phenomena, seeks an explanation in natural conditions alone. We will not here notice the misconstruction and personal abuse to which the latter thus exposes himself, and that, too, simply because he prefers truth, however shocking it may be to his earlier sentiments and beliefs, to the superstitious and ignorant dogmas of passionate partisans. I do not propose to enter here into anything of a polemical nature, and, least of all, to say anything which may jar upon the sentiments of any one, but to disenss the matter before us in a straightforward and philosophical way, without regard to preconceived opinions and feelingrs.

But while the scientifie investigator seeks in this direction an explanation of these moral facts, he does not in any way attempt to deny the existence of the facts themselves: On the contrary, his very inquiries 
presuppose their existence, for which indeed he encleavors to account.

That the individual does possess moral principles is a psychological fact, and the belief in their validity is as cogent in regulating and governing our conduct, whether the origin of such moral bcliefs shall be found in a slow psychological evolution through the force of the principle of utility, sympathy, or other equally efficient force, or in a special act of creation by which they become attributes of a spiritual essence. And it is perfectly evident that a moral principle, which las become evolved and recognized as desirable, may be impressed upon the mind by education, and so firmly implanted there through the law of association of ideas as to become a dominant factor in modifying the conduct of the individual. When once illeas have become strongly bound together by association,-and this is what moral principles are,-they exert a powerful influence over our actions and thoughts, and are not easily overcome by other feelings. In this respect they are like all other associations of ideas, the influence of which may be seen in political and religious beliefs, in our prejudices and other notions. And so strong may the inflnence of moral principles become from this cause that they may still continue to direct the conduct, though other processes of reasoning may logically convince us of the want of validity of the principles. Thus even those who are honestly convinced of the alssence of anything obligatory in iluty and other principles of ethics, still allow their conduct to be influenced by these notions, for the reason that by the time they have reached an age to think about such matters, their character has 
become so formed that they can only act in opposition to it at the expense of their mental happiness. These moral principles have then become antomatic, as it were. When this is the case, the same tendency to similar thought becomes transmitted to the offspring, who thus tends to inherit the same association of ideas or moral principles possessed by the parents, just as children inherit the ordinary peculiarities of character of the parents. In this respect, then, moral laws become innate or intuitive. However, it is a fact which cannot be gainsaid, that for the existence of moral prineiples it is requisite that the brain shall have acquired a certain degree of development. I think it will be found that moral prineiples become recognized as standards, even if not realized in practice, in direet proportion to the eapacity of the mind to originate abstract ideas, and that in the lower races only a very low standard of ethies can prevail among those people whose minds do not rise above the conception of specific objects. Some of the tribes of Oceanica and Australia have words for particular trees, as walnut-tree or beech-tree, ete., but none for a tree in the abstract. Such people cannot possess any abstract notion of a tree or any other object or quality.

It has been said that the "lowest among the Oceaneans and Africans (as the aboriginal Australians, the South Sea negroes, Bushmen, Central Africans, ete.) are entirely destitute of general ideas or abstract notions. Past and future concern them not. The Australian has no worls to express the idleas of God, religion, righteonsness, sin, ete. He knows almost no other sensation than the need of food, which he endeavors in 
every way to satisfy, and nakes known to the traveller by grimaces. 'In them the capability of considering and inferring,' says Hale (Natives of Australia, 1846), 'appears to be very imperfectly developed. The reasons which the colonists use in order to convince or persuade them are mostly such as are employed with children and half imbeciles." " 1

To have any code of ethics which shall approach the standard set by civilized nations, whether these nations be composed of Christians or Budllhists, it is essential that the mind shall be sufficiently developed to conceive of abstract notions, such as ideas of right and wrong, etc., and no religion can arise till the mind is capable of entertaining the idea of causation, etc.

The animals are probably content with the simple fact of existence, and never seek to know the reason or cause for that existence, the why or the how. They accept the fact without the idea ever entering their minds of inquiring further. The lowest races of men differ from the brutes very slightly in this respect. "I frequently inquired of the negroes," says Park, "what became of the sun during the night, and whether we should see the same sun or a different one in the morning, but I found that they considered the question as very childish. The subject appeared to them as placed beyond the reach of human investigation; they had never indulged a conjecture nor formed any hypothesis about the matter." 2

"A friend of Mr. Lang's 'tried long and patiently to make a very intelligent, docile, Australian black

1 Büchner, Man in the Past, Present, and Future. Eng. Trans., p. 313.

${ }^{2}$ Lubbock's Origin of Civilization, Amer. ed., p. 5. 
understand his existence without a body, but the black never could keep his countenance, and generally marle an excuse to get away. One day the teacher watched, and found that he went to have a hearty fit of laughter at the absurdity of the idea of a man living and going abont without arms, legs, or mouth to eat; for a long time he conld not believe that the gentleman was serious, and when he did realize it, the more serious the teacher was, the more ludicrous the whole affair appearerl to the black." "With a mind of such a character it is apparent that no religion worthy of the name could be conceived of, nor could we expect to find any moral principles of an exalted nature in force among such people. Whatever principles they may have must conduce only to the gratification of the appetites and passions.

"The aborigines of New Calerlonia, akin to the FejiIslanders, and belonging to the Papuan group, have, according to Van Rochas, no shame, go quite naked, and indulge in a number of excesses of the basest kind. They have intelligence as the beasts, but no moral emotions, are faithless in the highest degree, perjurerl, crafty, will strike any one down from behind, are cannibals, eating not merely their enemies, but even their own relatives, ean only witl difficulty count the lowest numbers, use strong abortives, and bury the aged alive. If a chief is lunngry, he straightway knocks down one of his subjects." 2

"The Australians," says a lady who emigrated to Australia, "live quite naked in huts of bark, in which

1 Lubbock's Origin of Civilization, Amer. ed., p. 245.

${ }^{2}$ Büchner, op. cit., p. 315. 
they sleep with their dogs. They eat anything,-insects, serpents, worms, roots, berries, etc.,- have no fixed dwelling-place, and are quite incapable of civilization. The missionaries have long given up every attempt to civilize them, for if one baptize them it has no more effect than the baptism of a dog or a horse; they understand nothing of the signification of the act. Marriages are very loose, infanticide is universal, the aged are put to death. They live only in the present, and think neither of the past nor the future. They cannot be taught any principles. They are dead to all morality. They know no sentiment, no spiritual life, no love, no gratitude, but only unbridled passion, and the sense of their nothingness against the white races." 1

But there is one mistake easy to fall into in considering the state of morality of communities, and this is to assume, because of the absence in the lower races of the moral laws which prevail among highly civilized nations, that therefore the former are totally lacking in morality. On the contrary, they often have laws which though to us seemingly absurd and withont reason, and not existing among civilized peoples, yet belong to the moral class, and prohibit, under the most stringent punishment, practices which are perfectly justifiable under our systems of government and codes of ethics. For example, among those nations which practice exogomy, that is, marriage only with individuals of a foreign tribe, marriage within the tribe is regarded as incest, and is punishable with death. This

1 Büchner, op. cit., p. 314. 
is the case among the Kurnai ${ }^{1}$ in Australia. Such people would regard our practice of marrying within our own caste or nationality as highly immoral and incestuous. One rather amusing custom among these people and, strangely enough, quite commonly diffused among similar tribes throughout the globe, is that of forbidding all social intercourse between mother-in-law and son-in-law. ${ }^{2}$ After marriage the son-in-law is not allowed even to speak to his mother-in-law.

Numerous other customs of a more important character, and which exert considerable influence upon the character of the race, might be mentioned as prevalent among varions races low in the scale of development.

Mr. Galbraith, who lived for many years, as Indian agent, among the Sioux (North America), thus describes them: they are "bigoted, barbarous, and exceedingly superstitious. They regard most of the vices as virtues. Theft, arson, rape, and murder are among them regarded as the means of distinction; and the young

1 "The Kamilaroi and Kurnai," by Lorimer Howitt and A. W. Fison.

2 "A Brabotung, who is a member of the Chureh of England, was one day talking to me. His wife's mother was passing at some little distance, and I ealled to her. Suffering at the time from cold, I could not make her hear, and said to the lirabotung, 'Call Mary, I want to speak to her.' He took no notice whatever, but looked varantly on the ground. I spoke to him again sharply, but still without his responding. I then said, "What do you mean by taking no notice of me?' He thereupon called out to his wife's brother, who was at a little distance, 'Tell Mary Mr. Howitt wants her.' And turning to me, continued, reproachfully, 'You know very well I could not do that; you know I cannot speak to that old woman." - Iamilaroi and Kurnai, p. 203. 
Indian from childhood is taught to regard killing as the highest of virtues. In their dances, and at their feasts, the warriors reeite their deeds of theft, pillage, and slaughter as precious things; and the highest, indeed, the only ambition of a young brave is to seeure 'the feather,' which is but a record of his having murdered or participated in the murder of some human being,-whether man, woman, or child, it is immaterial ; and after he has secured his first 'feather,' appetite is whetted to increase the number in his cap, as an Indian brave is estimated by the number of his feathers." 1

These Indians it is evident had moral laws, though they were of a very opposite standard from our own. It was probably a moral law which indueed the Spartans as well as savages to destroy the sickly children.

The extent to which some of the lower races will sacrifice their own feelings to their sense of duty, however distorted the latter may appear to us, is not often surpassed by more civilized people.

"The Feejeenns believe that 'as they die snch will be their condition in another world; hence their desire to escape extreme infirmity.' The way to Mbulu, as already mentioned, is long and difficult; many always perish, and no diseased or infirm person conld possibly succeed in surmounting all the dangers of the road. Hence as soon as a man feels the approach of old age, he notifies to his ehildren that it is time for him to die. If he neglects to do so, the children after a while take the matter into their own hands. A family consultation is held, a day appointed, and the grave dug. The

${ }^{1}$ Lubbock's Orjgin of Civilization. 
aged person has his choice of bing stianglel or buried alive. Mr. Hunt gives the following striking deseription of such a ceremony once witnessed by him. A young man came to him and invited him to attend his mother's funeral, which was just going to take place. Mr. Hunt accepted the invitation and joined the procession, but surprised to see no corpse, he made inquiries, when the young man ' pointed out his mother, who was walking along with them as gay and lively as any of those present, and apparently as mueh pleased. $\mathrm{Mr}$. Hunt expressed his surprise to the young man, and asked him how he could deceive him so much by saying his mother was dead, when she was alive and well. He said, in reply, that they had made her death-feast, and were now going to bury her; that she wats old, that his brother and himself had thought she had lived long enoughi, and it was time to bury her, to which she had willingly consented, and they were about it now. He had come to Mr. Hunt to ask his prayers, as they did those of the priest.

" "He added that it was from love for his mother that he hard done so; that in consequence of the same love, they were now going to bury her, and that none but themselves could or ought to do such a sacred office! Mr. Hunt did all in his power to prevent so diabolical an act; but the only reply he received was that she was their mother, and they were her children, and they ought to put her to death. On reaching the grave, the mother sat down, when they all, including ehildren, grandehildren, relations, and friends, took an atfectionate leave of her; a rope made of twisted tapa was then passed twice around her neek by her sons, who took 
hold of it and stra:gled her; after which she was put in her grave, with the usual ceremonies.

"So general was this enstom that in one town containing several hundred inhabitants Captain Wilkes did not see one man over forty years of age, all the old people having been buried." 1

On the other hand, as Lubbock has pointed out, a state of society where vice and crime are absent do not necessarily indicate a high moral standard. It may simply be due to negative virtue, to an absence of any inducement to commit crime, or to a mind so imperfectly developed as to be devoid of appetites or al desire to gratify them. Such persons can no more be praised for virtue than can the domestic cow be deserving of reward for refraining from murder or other human vices.

For the conception of a code of morality similar to that embraced by Christianity and Buddhism, there is required a brain of high organizatiou. Though the converse is not true, that a highly organized brain implies a high standard of morality, it only signifies the possibility of such a standard. There are large numbers of other conditions, those embraced under the social and politieal forces which determine the nature of the moral code in force among any people at any particular epoch. 'These conditions are beyond on' purpose to consider here, but I would eall attention to the fact that a distinction must be drawn between the theoretical and practical morality of a community, between the moral principles exemplified in the life of

1 Lubbock's Origin of Civilization, p. 248. 
the masses of the people and that standard advocated and practised only by the moral specialists. Just as at a time when the pagan Greeks were worshipping their false gods, the philosopher wise above his time, six hundred centuries before the birth of Christ, smiled at the simplicity and credulity of his fellows while he sang :

"There is one God supreme over all gods, diviner than mortals,

Whose form is not like unto man's, and as unlike his nature;

"But vain mortals imagine that gods like themselves are begotten,

With human sensations and voice and corporeal members;

"So, if oxen or lions had hands that could work in man's fashion,

And trace out with chisel or brush their conception of godhead,

Then would horses depiet gods like horses, and oxen like oxen, Each kind the divine with its own form and nature endowing." 1

In estimating the moral condition of a people, as Lecky has well remarked, it is necessary to consider both the moral code advocated as a standard and the actual habits of the people themselves. ${ }^{2}$

1 Xenophanes of Colophon.

2 "In estimating, however, the moral condition of an age, it is not sufficient to examine the ideal of moralists. It is necessary, also, to inquire how far that ideal has been realized among the people. The corruption of a nation is often refleeted in the indulgent and selfish ethics of its teachers; but it sometimes produces a reaction, and impels the moralist to an aseeticism which is the extreme opposite of the prevailing spirit of society. The means which moral teachers possess of acting upon their fellows vary greatly in their nature and efficacy, and the age of the highest moral teaching is often not that of the highest gen- 
For a high standard of morality not only is it essential that the brain should be highly developed and capable of forming abstract conceptions, which shall be so firmly implanted in it, as it were, as to automatically govern our thoughts and actions, but the acquisition of extended experience and knowledge is necessary for the development of these moral conceptions. When this latter is lacking we find either the moral standard is low, or, if high, is only in practice of limited application. 'Thus the Indian, who regards the murder of one of his own tribe as a moral crime, considers the killing of an individual of a foreign tribe as the highest virtue. And even among nations boasting of Christian civilization, we find different standards of ethics in force within the nation from that which it practises between itself and foreign nations. National and international ethics are two different things. When our knowledge becomes so far extended that each nation shall perceive that the results of a high degree of morality will be as beneficial to a nation in its relations to another as in the relations between individuals, a much higher interuational moral code will be established than exists to-rlay, and as the principles become ingrained in the mind, they will tend by inheritance and elucation to become automatic and dominant in regulating international conduct.

After those modes of thought called moral principles have become established and automatic, it makes no

eral level of practice. . . In addition, therefore, to the type and standard of morals inculcated by the teachers, an historian must investigate the realized morals of the people."-Lecky's History of European Morals. Preface. 
difference by what process they have become evolved. Whatever it may be, their influence in dominating the conduct is the same. We refrain from doing any act because we think it is wrong, and we do something else because we think it is right, and we judge it is right or wrong according as it is or is not in harmony with certain fixed principles which have been formulated as standards.

But while this is the case, the different schools of philosophy markedly differ in the incentives which each offers to induce an adherence to moral principles.

In the theological school a system of rewards and punishments plays a very important part at least, and in the past has played a greater part. People have been taught to act honestly and uprightly in order that they may hereafter be rewarded, and warned against immorality by the fear of future punishment. We are urged to a certain course of action for our own good and for our own benefit. Compare such a code with that offered by materialism and see if the latter loses by the comparison. Instead of being reminded of reward and punishment, we are told to act uprightly for the common benefit of humanity and of the human race, not for the sake of benefiting ourselves alone. The individual is edneated to regard the good of the many as that for which the individual should strive, and his reward and punishment is to be found in the happiness or unhappiness of his fellow-beings.

An Italian Jesuit priest, who made it his duty to attend those dying in one of our hospitals and help their sonls onwards as they started on their final jourucy, once fell into argument with me on the subject of 
religion. Becoming finally heated with the argument, he exclaimed, with more candor than caution, "I do not care for the broken arms and the broken legs; the hospital might burn up, I would not care. It is a little. corner for myself in the beautiful land I wish to make." I suppose that he regarded each soul saved as seoring one for himself.

Though no one would impute such selfish motives to the majority of mankind, still it is hard to deny that they enter into theological morality.

Though this system may be justified by the fact that the world is not yet prepared for a higher code, such as that offered by materialism, the system is not thereby elevated. It is a fact, and a melancholy one, that human vature is weak, and in its present state of development requires to be stimulated by the promise of reward, and to be checked by the threat of punishment; and so-called moral philosophers would, if they were really philosophers, recognize this fact with its necessary consequences, and cease to rail at the existing order of things, and refrain from thrusting their own systems of philosophy, however elevating theoretically, upon a world umprepared for them.

Theological ethics is that best snited for the control of man as he now exists. Whether mankind will in the future attain to a degree of developnent which will enable the individual to perform a duty for duty's sake, without hope of reward or fear of punishment, is a question which belongs to the domain of speculation.

At present, however humiliating may be the thought, man, like the brute, can only be tamed and morally erlucated by the alternate use of sweetmeats and the lash. 






University of California SOUTHERN REGIONAL LIBRARY FACILITY 305 De Nave Drive - Parking Lot 17 - Box 951388 LOS ANGELES, CALIFORNIA 90095-1388

Return this material to the library from which it was borrowed. 
iversi

Soutr

$\mathrm{Lib}$ 